SUIE SENMNOLES

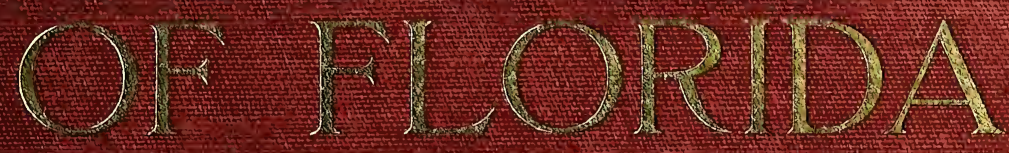

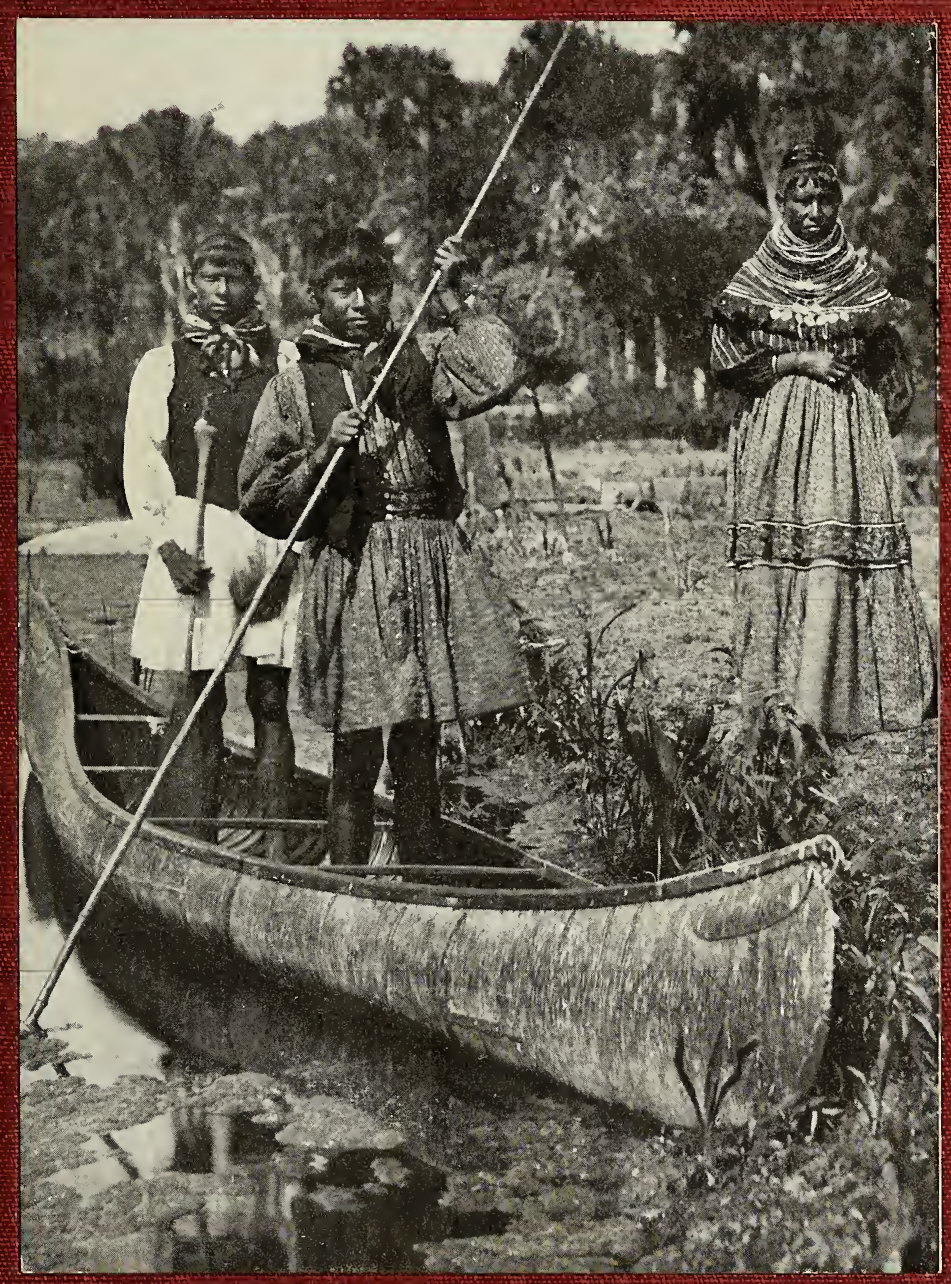

MUNNIE VIOORE-WILLSON 
Smithsonian

Institution

Libraries

\section{Bequest}

from the library

$$
\text { of }
$$

William C. Sturtevant 


THE SEMINOLES OF FLORIDA 




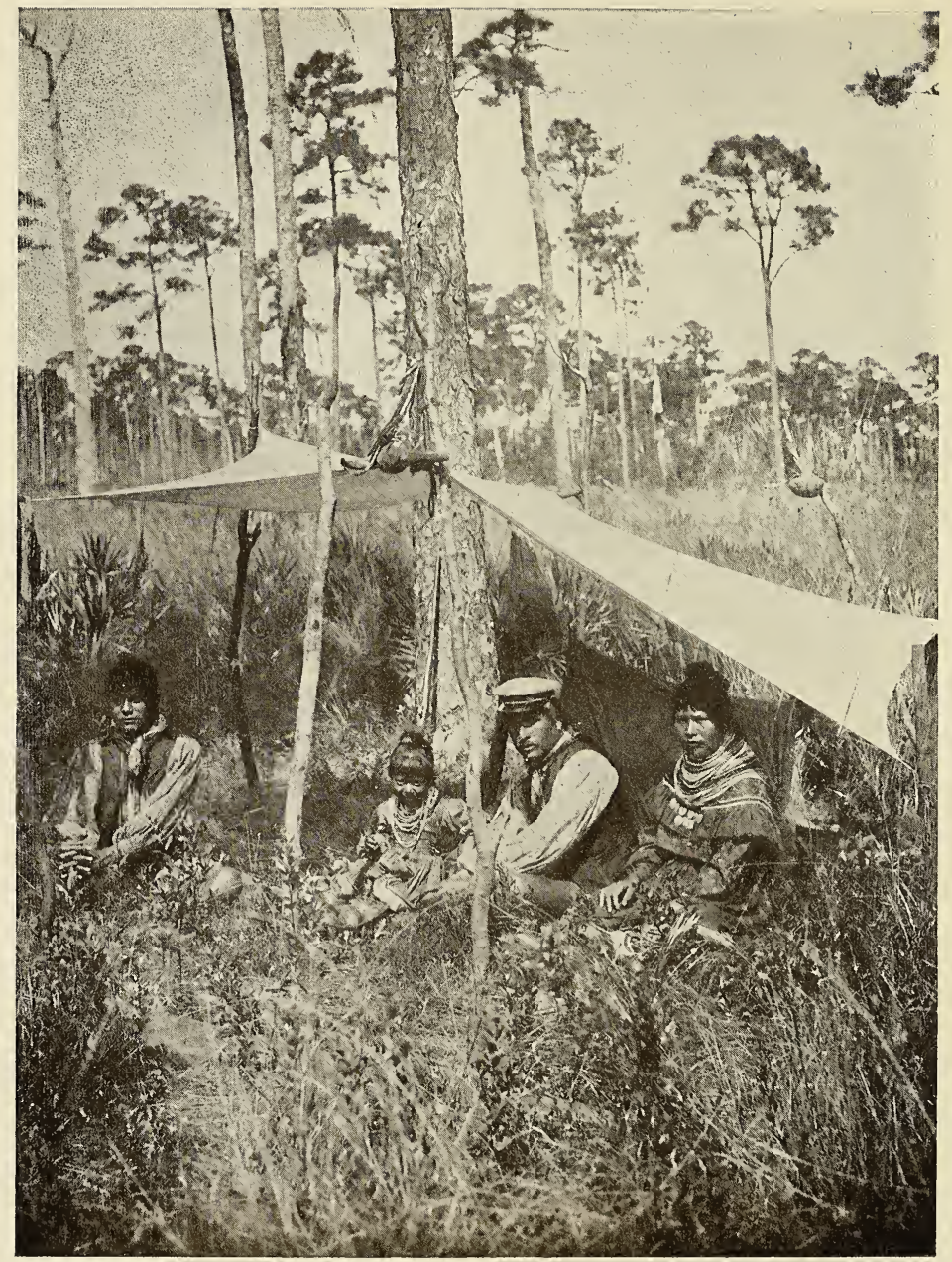

Photograph by E. W. Histed.

HOKE-TI-CHEE. LITTLE GIRL WITH THE BRIGHT EYES 


\title{
THE SEMINOLES OF FLORIDA
}

MINNIE MOORE-WILLSON

\author{
ILLUSTRATED
}

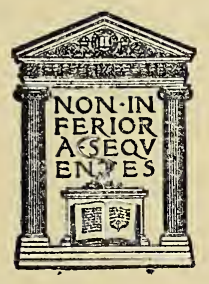

NEW YORK

MOFFAT, YARD AND COMPANY

I9IO 
Copyright i 896 , igio by MINNIE MOORE-WILLSON 
MRS. ELIZABETH STAUFFER-MOORE

IN GRATEFUL RECOGNITION OF HER SYMPATHY AND PHILANTHROPIC INTEREST IN BEHALF OF THIS BRAVE AND HEROIC REMNANT OF THE ABORIGINAL AMERICANS, THE SEMINOLES OF FLORIDA, THIS BOOK IS AFFECTIONATELY DEDICATED

By the AUthor. 



\section{FOREWORD}

When most of the Seminoles were moved from Florida to Indian Territory, a few score of them were unwilling to go. Of these who remained, the decendants, ten years ago, numbered about six hundred. An effort was made at that time to buy for this band the land on which they lived and a few hundred dollars was given for that purpose.

In the study of this fragment in their singular surroundings as portrayed in the pages of this book, one gets, as it were, a glimpse of their camp-fire life, a view of their sun-bleached wigwams and an insight into the character of these proud but homeless people.

Not much apparently can be done for this homekeeping remnant of the Florida aborigines, but it is help and a protection to them that their continuing presence in Florida and the conditions of their life there should be known to the rest of the Americans and especially to those who go to Florida or are concerned with the development of that State.

To diffuse this helpful knowledge and give these Indains such protection as may come from it, is the aim of the present book.

EDWARD S. MARTIN.

New, York, Nov. 9, I909. 


\section{EDITOR'S NOTE.}

In this enlarged and illustrated edition of "The Seminoles of Florida," the demand for which seems to come insistently from every hand, the author wishes to acknowledge the courtesy and great kindness of Mr. C. B. Reynolds and Mr. E. W. Histed for their assistance in its illustrations. 


\section{CONTENTS}

PART FIRST.

PAGE

Facts of the Earlier Days . . . . . . . . . . I

Origin of Troubles . . . . . . . . . . . . . . 6

EfForts at Indian Removal . . . . . . . . . . II

The Massacre of General Thompson and of Dades' Forces I5

A Dishonored Treaty . . . . . . . . . . . . . . I9

As-SE-HO-LAR, The RISING SUn, OR OsCEOla . . . . . $2 \mathrm{I}$

Osceola's Cafture . . . . . . . . . . . . . . 26

The Hidden War Camp . . . . . . . . . . . . 30

Wild Cat and General Worth . . . . . . . . . 33

INDIAN WARfARE . . . . . . . . . . . . . 38

“Dat Seminole Treaty Dinner" • . . . . . . 4I

\section{PART SECOND.}

The Present Condition and Attitude of the Seminoles . 53

National Indian Association, Its Work and Its Results,

Episcopal Mission . . . . . . . . . . . . 65

The Friends of the Florida Seminoles . . . . . . . 68

Our Duty to These Wards of the Nation . . . . . 76

Chieftain Tallahassee . . . . . . . . . . . . 79

INCREASING . . . . . . . . . . . . . . . . 84

Appearance ANd Dress . . . . . . . . . . . . 87

INDEPENDENCE AND HONOR . . . . . . . . . . . 90

The Seminole's Unwritten Verdict of the White Race • 93

Endurance and Feasts . . . . . . . . . . . . 95

The Hunting Dance . . . . . . . . . . . . IOO

Slavery . . . . . . . . . . . . . . . . I06

HANNAH . . . . . . . . . . . . . . . . . IO7

UNWRITTEN LAWS . . . . . . . . . . . . . . IO8

Gens ANd Marrtage . . . . . . . . . . . . . II4 


\section{CONTENTS}

PAGE

Beauty and Music . . . . . . . . . . . . il6

Relationship to the Aztecs and Eastern Tribes . . . II8

Seminoles at Home - The Everglades . . . . . . . I26

Alligator Hunting . . . . . . . . . . . . . I39

Bear Hunting with the Seminoles . . . . . . . . I42

Captain Tom Tiger (Mic-co-Tus-te-nug-ge) . . . . I 48

Nancy Osceola • • • • • • • • . • • • . . I54

Billy Bowlegs . . . . . . . . . . . . . . I55

RELIGION . • • • • • • . • • • • • • . . • I62

Bought BACK . . . . . . . . . . . . . . I68

MOUNDS . . . . . . . . . . . . . . . . . I69

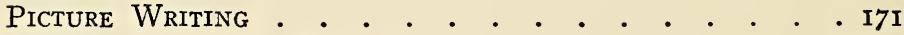

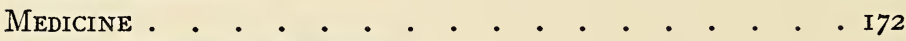

Abiding Words of Beauty . . . . . . . . . . . I74

Conclusion •. • . . . . . . . • • • . . I79

PART THIRD.

INTRODUCTION TO Vocabulary • . . . . . . . . . I85

Words Regarding Persons . . . . . . . . . . . I87

Parts of Body . . . . . . . . . . . . . . . I 88

DRess and ORnaments • . • . . . . . . . . . Igo

DWELlings, ImPlementS, ETC. • • • • • • • . . 192

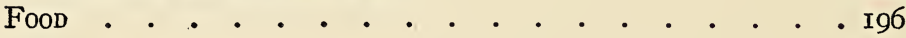

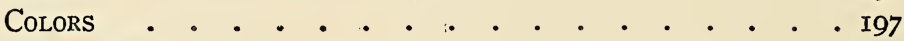

Numerals • • • • • • • • • • • • • • • . I97

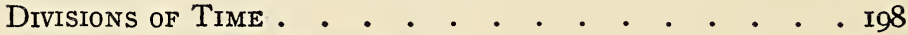

Animals, Parts of Body, ETC. . . . . . . . . . . 200

BIRDS • . . . . . . . . . . . . • . . . . 201

FISH AND ReptILES . . . . . . . . . . . . . 202

INSECTS . . . . . . . . . . . . . . 203

Plants . • . . • . • • • • • • • . . 204

The Firmament, Physical Phenomena, etc. . . . . 205

KINSHIP . • • • • • • • • • • • • . • • 206

Verbs, Phrases, Sentences . . . . . . . . . . . 207

Indian Names of Some Present Seminoles . . . . . 210

Rhythmical Names of Some Florida Rivers and Towns . $2 \mathrm{I} 2$ 


\section{LIST OF ILLUSTRATIONS}

PAGE

Hoke-ti-chee, "Little Girl with the Bright Eyes" .: . . . . . . . . Frontispiece

Florida Indians Carrying Their Crops to the

Storehouse . . . • . . . . 6

An Indian Retreat During the Seminole War . . . I6 Micanopy . . . . . . . . . . . . . 20

One of the Last Seminole Battle Grounds . . . . 24

Osceola • • • . . • • • • • . . . . . 30

Martha Jane, "Bandanna Mammy" . . . . i. 42

A Seminole Dwelling •: •. . . . . . . . 10 60

A Seminole Camp-fire :.

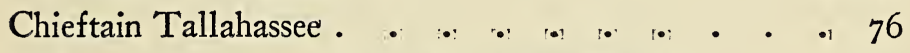

A Seminole Group of the Tallahassee Band . . . 86

Chief Tallahassee, Martha Tiger, She Yo

Hee, Tommy Hill and Milakee :o: tol • • 90

Billy Bowlegs and Tommy Doctor . • . . . 98

Hannah, The Only Remaining Slave of the

Seminoles • •. . . . . . . . . . 108

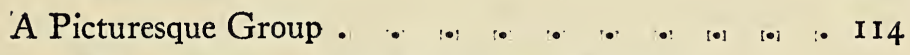

An Enchanting Study of the Younger Genera-

tion • • • • • • • • • • • • • • . 122

Seminoles on the Miami River . . . . . 130

Tiger Tail . . . . . . . . . . . . I40 


\section{ILLUSTRATIONS}

Indian Mode of Hunting Alligators in Flor-

PAGE

ida . . . . . . . . . . . . . 144

Captain Tom Tiger . .. • ๑. . . . . . 148

The Indian's Hunting Ground . . . . . . 150

A Section of a San Grass Swamp . . . . . 156

Billy Bowlegs and Doctor Tiger . . . . . . . 160

Hi-a-tee, Captain Tom Tiger, Ho-ti-yee and

"Little Tiger" . . . . . . . . . . I64

Dr. Jimmie Tustanogee with His two Wives and the Children . . . . . . . . . 168

Billy Buster, Tommy Hill, Tallahassee and

Charlie Peacock . . . . . . . . . . I72

The Wild Heron in Domestication . . . . . . 176

The White Plumed Egret in a Florida Yard . . . 180 


\section{PREFACE}

That there is yet a tribe, or tribes of Indians in Florida is a fact unknown to a large part of the people of this country; there are even students of history who have scarcely known it. These people, driven, about seventy or more years ago, into the dreary Everglades of that Southern Peninsular, have kep $t$ themselves secluded from the ever encroaching white population of the State. Only occasionally would a very small number visit a town or a city to engage in traffic. They have had no faith in the white man, or the white man's government. They have aimed to be peaceful, but have, with inveterate purpose, abstained from intercourse with any of the agencies of our government. My friends, Mr. and Mrs. J. M. Willson, Jr., of Kissimmee, Floride, have found their way to a large degree of confidence in the hearts of this people. They have learned something of their history, and have studied their - manner of life, their character and habits.

Mr. Willson has been allowed, and invited to go with some of their men on familiar hunting expeditions. He has seen them in the swamps, in their homes, and in their general life environments. $\mathrm{He}$ has been admitted to their confidence and friendship. $\mathrm{He}$ has consequently become deeply interested in 


\section{PREFACE}

them. Mrs. Willson also has become acquainted with some of their chief personages. Both have lcarned to sympathize with these Indians in their hardships and in their treatment at the hands of the white race.

Mrs. Willson began to write about them and her writing has grown into a book; and she has been encouraged to give this book to the world, in the hope that the attention of good people may be drawn toward them, and that at least a true interest may be awakened in their moral and material well-being. They are truly an interesting people, living, although secluded, almost at our doors.

Mrs. Willson has written earnestly, enthusiastically, and lovingly regarding them, and it is to be hoped that a new interest may soon be taken in them both by the churches and the government, and that they may soon enter upon new realizations, and be encouraged to place a confidence in the white race to which, until quite recently, they have been utter strangers.

Mr. Wilison has prepared the vocabulary. The words and phrases here given have been gathered by him in the course of ten or fifteen years of friendly intercourse with members of the tribe. They have assisted him in getting the true Indian or Seminole word and in finding its signification. Old Chief Tallahassee has been especially and kindly helpful; so has Chief Tom Tiger. This vocabulary of this peculiar Indian tribe, though not complete, ought to prove helpful to those who are interested in the languages 


\section{PREFACE}

of the people who roamed the forests of this great land before it became the home and the domain of those who now live and rule in it.

This book, in its first part, gives some account of the earlier years of the Seminole history. In the second part the reader is introduced to the later and present state of things and facts regarding them.

In the third part is found the vocabulary - a number of Seminole words, phrases and names, with their interpretation into our own tongue.

This little book is given to the world in the hope - that it will be found both interesting and valuable to many readers.

R. BRAden MOORE. 



\section{THE SEMINOLES OF FLORIDA}

\section{PART FIRST}

Facts of Earlier Days

THE history of the American Indian is a very Iliad of tragedy. From the day Columbus made the first footprints of the European in the damp sands of Cat Island, the story of the original owners of fair America has been full of melancholy, and fills with its dark pages every day of a quartet of centuries.

Columbus describes the innocent happiness of these people. "They were no wild savages, but very gentle and courteous," he says, "without knowing what evil is, without stealing, without killing." They gave to him a new world for Castile and Leon, while in exchange he gave to them "some glass beads and little red caps." The tragedy of the new world began when we find this same admiral writing to the Spanish majesties that he would be able to furnish them with gold, cotton, spices, and slaves - "slaves! as many as their Highnesses shall command to be shipped "; and thus, this land, a paradise of almost primeval loveliness, was transformed into a land of cruel bondage, desolation and death.

History scarcely records an instance when hospital- 
ity was not extended by the red man to our first explorers. Swift canoes shot out from the shaded shores, filled with men clad in gorgeous mantles, and, in broken accents, their greeting was "Welcome!" "Come, see the people from Heaven," they cried, but were soon destined to believe they were from a very different region.

From old Spanish accounts we conclude that the Indian population of De Soto's time was very large, and that the natives were in a higher state of civilization than at any later period; that their speech, though brief, was chaste, unaffected, and evinced a generous sentiment. Cortez found the Aztecs and their dependencies challenging comparison with the proudest nations of the world, and in their barbarous magnificence rivaling the splendors of the Orient. Advanced in the arts, dwelling in cities, and living under a well-organized government, they were happy in their position and circumstances.

Who were the barbarians of the early history of America, our Mayflower ancestors, or the Red Men of the forest?

With a careful study of the early records, the question answers itself.

Four hundred years ago Indian warfare began. Shall it continue until we exterminate the race? When it is, alas, too late, the American people will awaken to the fact that the preservation of the Indian race will be a theme that will stir the very heart of the Nation.

Shall Justice blush as the future historian pens the 
account of the vanished Indian and our treatment of his race? Will Patriotism hang her head in shame and confusion as the pen portrays the history of the red heroes, who gave up their lives for their home and liberty?

Since that sunny day in May, I 539, when De Soto, amid the salutes of artillery, the music of trumpets, the cheers of thousands of Castilians, sailed into Tampa Bay, Florida, has been the scene of stirring events - with the Aborigines forming a tragical background.

Marching across the flower-bedecked country with his gallant men of Spain, with his cavalry, with fleet greyhounds and furious bloodhounds to turn loose upon the savages, also handcuffs, chains and collars to secure them, with priests, workmen and provisions, this proud adventurer reached the present site of Tallahassee. Here, in this vicinity, they came upon a fruitful land, thickly populated.

Ever pressing onward for the gold that was supposed to abound in this new land, one village after another was passed, when provisions and welcome were furnished by the Laziques.

On, on, the proud and haughty Spaniards marched, until they reached the province of Cofaqui. Here the splendor of the reception would amaze us, even to-day. The chieftain and the people gave up their village for the Spanish quarters, moving to another town for the occasion. The following day the chief returned, offering De Soto 8,000 armed Indians, with maize, dried fruits and meat for the 
journey, 4,000 to act as defenders, 4,000 as burden bearers, to escort the Spaniards through a wilderness of several days' journey. Such were the proud and generous people the Caucasians found in America.

The haughty Castilian continued his march till he reached the banks of the Mississippi, where he halted and sent his carrier to the chief on the opposite shore, with the usual message, that he was the "Offspring of the Sunne, and required submission and a visit from the chief." But the chieftain sent back a reply, both magnanimous and proud, that if he were "the Childe of the Sunne, if he would drie up the River, he would believe him; that he was wont to visit none; therefore, if he desired to see him he would come thither, that if he came in peace he would receive him in special good will, and if in Warre in like manner he would attend him in the Towne where he was and for him or any other he would not shrinke one foot backe."

Old. history says this haughty repulse aggravated the illness of De Soto, "because he was not able to passe presently to the River and seeke him, to see if he could abate that Pride of his."

Notwithstanding the hospitable treatment shown by the natives to the newcomers, the Castilians destroyed them by the thousands: One explorer after another wrote of these friendly people in the new land. "They are very liberal," says the narrator, "for they give what they have." Sir Ralph Lane describes the welcome by the natives, who came with 
"Tobacco, Corne and furs and kindly gestures to be friends with the strange white men," etc., etc., but adds, "the Indians stole a Silver Cup, wherefore we burnt their Towne and spoylt their Corne," etc., etc.

The time will soon be over for the study of the Aborigines of America. We have in $25^{\circ}$ years wasted them from uncounted numbers to a scattering population of only about 275,000 , while in the same length of time a cargo of dusky slaves from the African shores have become a people of millions, slaves no longer, but protected citizens. In the redskin, whom we have dispossessed of his native rights, we recognize no equality; yet the descendant of the barbarous black, whose tribe on the Golden Coast still trembles before a fetish, may now sit at the desk of Clay or Calhoun. Truly the tangled threads of modern morals are hard to unravel.

The first explorers made captives of the Indians, and carried them in irons to Spain, where they were sold as slaves to the Spanish grandees. Two hundred years later the people of Carolina sought to enslave those among them. The red men rebelled at the subjection, and in order to escape bondage, began to make their way to the "Indian country," the present site of Georgia. African bondsmen soon followed the example of the Indian captives, and in time continued their journey to Florida.

In the attempts to recapture runaway slaves, is based the primeval cause of the Seminole wars. 


\section{ORIGIN OF TROUBLES.}

The history of the Seminoles of Florida begins with their separation from the Creeks of Georgia as early as 1750 , the name Seminole, in Indian dialect meaning wild wanderers or runaways. Seacoffee, their leader, conducted them to the territory of Florida, then under Spanish colonial policy. Here, they sought the protection of Spanish laws, refused in all after times to be represented in Creek councils, elected their own chiefs, and became, in all respects, a separate tribe.

To-day the Seminoles of Florida are only a frail remnant of that powerful tribe of Osceola's day. Their history presents a character, a power, and a romance that impels respect and an acknowledgment of their superiority. Of the private life of the Semnole less is known, perhaps, than of any other band in the United States. His life has been one long struggle for a resting-place; he has fought for home, happy hunting grounds and the burial place of his fathers. At present we can only see a race whose destiny says extinction.

The wilds of Florida became a home for these Indians as well as for the fugitive negro slaves of the Southern States. The Indian and the negro refugee, settling in the same sections, became friendly, and in time some of their people intermarried. The same American spirit that refused to submit to "Taxation without Representation," was strong in the breast of the Seminole, and Florida, belonging to Spain, af- 


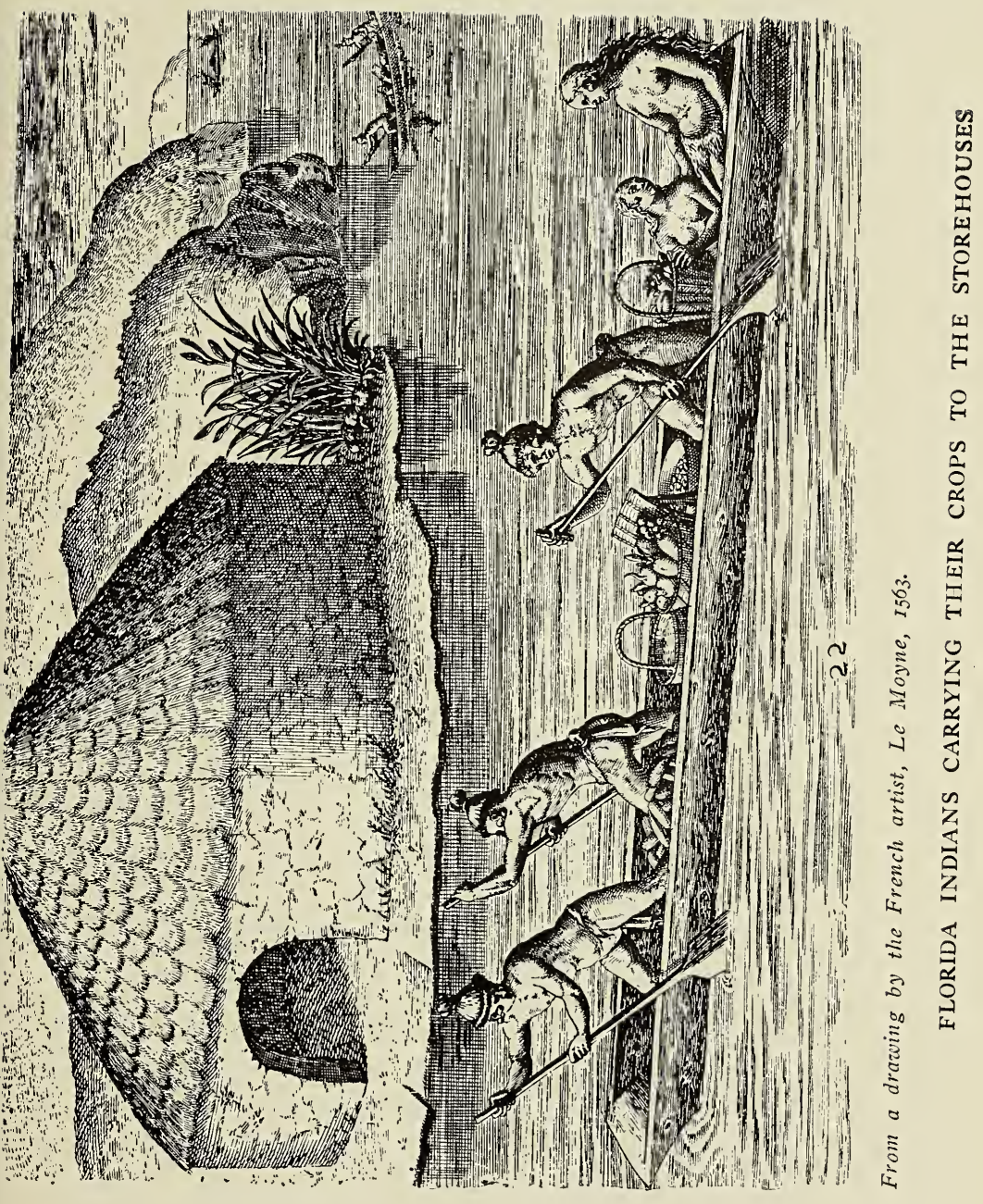





\section{THE SEMINOLES OF FLORIDA}

forded him a retreat for his independent pursuits. Subject only to the Spanish crown, the exiles found a home safe from the inexorable slave catchers. The Seminoles were now enjoying liberty, and a social solitude, and refused to make a treaty with the colonial government, or with the Creeks from whom they had separated. One demand after another was made upon the Spanish government at St. Augustine for the return of the fugitives, which was always rejected. African slaves continued to flee from their masters to find refuge with the exiles and the Indians. They were eagerly received, and kindly treated, and soon admitted to a footing of equality. The growing demand for slaves in the southern colonies now made the outlook serious, and from the attempts to compel the return of the negroes grew the first hostilities.

One of the first communications ever sent to Congress after it met was by the Georgia colony, stating that " a large number of continental troops would be required to prevent the slaves from deserting their masters." But, in that momentous year of 1776 , Congress had more important duties on hand, and it was not until I 790 that a treaty was entered into between the Creeks and the United States. In this treaty, the Creeks, now at enmity with the Seminoles, agreed to restore the slaves of the Georgia planters who had taken refuge among them. The Seminoles refused to recognize the treaty; they were no longer a part of the Creeks, they resided in Florida and considered themselves subject only to the crown 
of Spain. One can readily believe that the Spanish authorities encouraged their independence. Legally the exiles had become a free people.

The Creeks now found themselves utterly unable to comply with their treaty. The planters of Georgia began to press the Government for the return of their fugitive slaves. Secretary Knox, foreseeing the difficulty of recovering runaway slaves, wrote to the President advising that the Georgia people be paid by the Government for the loss of their bondmen. The message was tabled, and until i 8 io the Seminoles and negroes lived in comparative peace.

The people of Georgia, now seeing the only apparent way to obtain possession of their slaves would be by the annexation of Florida, began to petition for this, but the United States, feeling less interest in slave catching than did the State of Georgia, manipulated affairs so slowly that Georgia determined to redress her own grievances, entered Florida and began hostilities. The United States was too much occupied with the war with Great Britian to take cognizance of Indian troubles in a Spanish province, hence the Georgia intruders met with defeat. For a short time after these hostilities ceased the Seminoles and their allies enjoyed prosperity, cultivated their fields, told their traditions and sang their rude lays around their peaceful camp fires. Seventy-five years had passed since their ancestors had found a home in Florida, and it was hard for them to understand the claims of the southern planters.

The year 18 I 6 found the Seminoles at peace with 
the white race. In a district inhabited by many of the Indians on the Appalachicola river was Blount's Fort.

The fort, although Spanish property, was reported as an "asylum for runaway negroes." General Jackson, now in military command, ordered the "blowing up of the fort, and the return of the negroes to their rightful owners." The exiles knowing little of scientific warfare believed themselves safe in this retreat; and when in 1816 an expedition under Colonel Duncan L. Clinch was planned, the hapless Indians and negroes unknowingly rushed into the very jaws of death. A shot from a gunboat exploded the magazines and destroyed the garrison. History records that of 334 souls in the fort, 270 were instantly killed! The groans of the wounded and dying, the savage war whoops of the Indians inspired the most fiendish revenge in the hearts of those who escaped, and marks the beginning of the First Seminole War.

Savage vengeance was now on fire, and "Blount's Fort" became the magnetic war cry of the Seminole chiefs as they urged their warriors to retaliation. This barbarous sacrifice of innocent women and children conducted by a Christian nation against a helpless race, and for no other cause than that their ancestors, one hundred years before, had been born in slavery, marks a period of cruelty, one of the most wanton in the history of our nation.

The inhuman way in which the massacre was conducted was never published at large, nor does the 
War Department have any record of the taking of Blount's Fort, as is shown by the following:

An examination of the records of this Department has been made, but no information bearing upon the subject of the taking of Blount's Fort, Florida, in the year 1816, has been found of record.

By authority of the Secretary of War,

F. C. Ainsworth, Colonel, U. S. Army, Chief of Office.

Washington, July 25, 1895 .

History does not dwell on the cruel treatment the Indians received from the United States authorities during the Seminole Wars, yet pages of our National Library are devoted to the barbarity of the Seminoles. There are two sides to every question, and it is only what the Indian does to the white man that is published, and not what the white man does to the Indian.

The facts show that instead of seeking to injure the people of the United States, the Seminoles were, and have been, only anxious to be free from all contact with our government. In no official correspondence is there any reference made to acts of hostility by the Indians, prior to the massacre at Blount's Fort.

But Floridians, who had urged the war with the hope of seizing and enslaving the maroons of the interior, now saw their own plantations laid waste, villages abandoned to the enemy, and families suffering for bread. The war had been commenced for 
an ignoble purpose, to re-enslave fellow-men, and taught that every violation of justice is followed by appropriate penalties.

Few of the people of the United States knew the true cause of the war, nor the real inwardness of the purposes of those in command, as history and official documents show that affairs were in the hands of the Executive rather than in those of Congress. The first war was in itself an act of hostility to the King of Spain; yet nothing was gained by our government except possession of part of the fugitives. Military forces could not pursue the Indians into the fastnesses of the Everglades, and after two years of bloodshed and expenditure of thousands of dollars, peace was in a manner restored, and the army was withdrawn without any treaty being signed.

\section{EFFORTS AT INDIAN REMOVAL.}

The Indians had set the American government at defiance. The slaves of Southern States continued to run away, taking refuge with the exiles and Seminoles; the slave-holders of Georgia became more clamorous than ever. The Spanish crown could not protect herself from the invasion of the Americans when in pursuit of runaway negroes. She had seen her own subjects massacred, her forts destroyed or captured, and her rights as a nation insulted by an American army. In 1819 , by a combination of force and negotiation, Florida was purchased from Spain for $\$ 5,000,000$. 


\section{THE SEMINOLES OF FLORIDA}

Thus the Seminoles were brought under the dominion they so much dreaded. Slave-holders once more petitioned to the United States for aid in the capture of their escaped property. The United States, foiled in their treaty with the Creeks, now recognized the Seminoles as a distinct tribe, and invited their chiefs to meet our commissioners and negotiate a treaty. The Seminoles agreed in this treaty to take certain reservations assigned to them, the United States covenanting to take the Florida Indians under her care and to afford them protection against all persons whatsoever, and to restrain and prevent all white persons from hunting, settling or otherwise intruding upon said lands.

By this treaty all their cultivated lands were given up to the whites, and the Seminoles retired to the interior. Once more this long persecuted people found refuge, but it was only for a short time. The value of slaves in States North caused slave catchers with chains and bloodhounds to enter Florida. They seized the slaves of the Indians, stole their horses and cattle and depredated their property. With such a violation of the treaty, renewed hostilities were inevitable.

The Indians petitioned for redress, but received none. Affairs grew worse until I 828, when the idea of emigration for the Indians was submitted to the chiefs. After much persuasion, a few of the tribal leaders were induced to visit the Western country. They found the climate cold, and a land where "snow covers the ground, and frosts chill the bodies 
of men," and on general principles, Arkansas a delusion and a snare. The chiefs had been told they might go and see for themselves, but they were not obliged to move unless they liked the land. In their speech to the Commissioner they said: "We are not willing to go. If our tongues say 'yes,' our hearts cry 'no.' You would send us among bad Indians, with whom we could never be at rest. Even our horses were stolen by the Pawnees, and we were obliged to carry our packs on our backs. We are not hungry for other lands; we are happy here. If we are torn from these forests our heartstrings will snap." Notwithstanding the opposition to a treaty, by a system of coercion a part of the chiefs were induced to sign, and fifteen undoubted Seminole cross-marks were affixed to the paper. This was not enough, according to Indian laws, to compel emigration. The stipulations read, "Prepare to emigrate West, and join the Creeks." There was no agreement that their negroes should accompany them, and they refused to move. To expect a tribe which had lived at enmity with the Creeks since their separation in $175^{\circ}$ to emigrate and live with them was but to put weapons into their hands, and did not coincide with the ideas of the Seminoles.

The United States prepared to execute; not a redskin was ready, and troops were sent. The Indians began immediately to gather their crops, remove the squaws and pickaninnies to places of safety, secure war equipments - in short, prepare for battle.

It was a question of wonderment many times 
among the officers how the Indians procured their ammunition in such quantities, and how they kept from actual starvation. Hidden as they were in their strong fortresses - the fastnesses of the swamps many believed that they would be starved out, and would either stand a fair field fight or sue for peace. An old Florida settler who carried his rifle through seven years of Indian warfare explains the mystery. He says: "The Indians had been gathering powder and lead for years, ever since the time Chief Neamathla made his treaty with General Jackson. Besides, Cuban fishing smacks were always bringing it in, and trading with the redskins for hides and furs. As for provisions, they had their 'Koontie' flour, the acorn of the live oak, which is fair eating when roasted, and the cabbage of the palmetto tree. For meat, the woods were full of it. Deer and bear were abundant, to say nothing of small game, such as wild turkey, turtle and squirrel." The Seminoles at this time, I834, owned, perhaps, two hundred slaves, their people had intermarried with the maroons, and in fighting for these allies they were fighting for blood and kin. To remove the Indians and not the negroes was a difficult thing to do. The Seminoles, now pressed by the United States troops, committed depredations upon the whites; bloody tragedies occurred, and the horrors of the second Seminole War were chronicled throughout the land. 
THE MASSACRE OF GENERAL THOMPSON AND OF DADES' FORCES.

It was now that the young and daring warrior, Osceola, came into prominence. $\mathrm{He}$ had recently married the daughter of an Indian chief, but whose mother was the descendant of a fugitive slave. By slave-holding laws, the child follows the condition of the mother, and Osceola's wife was called an African slave. The young warrior, in company with his wife, visited the trading post of Fort King for the purpose of buying supplies. While there the young wife was seized and carried off in chains. Osceola became wild with grief and rage, and no knight of cavalier days ever showed more valor than did this Spartan Indian in the attempts to recapture his wife. For this he was arrested by order of General Thompson and put in irons. With the cunning of the Indian, Osceola affected penitence and was released; but revenge was uppermost in his soul. The war might succeed or fail for all he cared; to avenge the capture of his wife was his every thought. For weeks he secreted himself, watching an opportunity to murder General Thompson and his friends. No influence could dissuade him from his bloody purpose. Discovering General Thompson and Lieutenant Smith taking a walk one day, Osceola, yelling the war cry sprang like a mountain cat from his hiding-place and murdered both men.

His work of vengeance was now complete, and almost as wild as a Scandinavian Saga was the fight 
he now gave our generals for nearly two years. While Osceola lay in wait for General Thompson, plans were being completed which resulted in the Dade Massacre.

The enmity of the Indian is proverbial, and when we reflect that for fifty years the persecutions by the whites had been "talked" in their camps, that the massacre of Blount's Fort was still unavenged, that within memory fathers and mothers had been torn, moaning and groaning from their midst, to be sold into bondage, with their savage natures all on fire for retaliation, no vengeance was too terrible.

Hostilities around Fort King, now the present site of Ocala, becoming severe, General Clinch ordered the troops under Major Dade, then stationed at Fort Brooke (Tampa), to march to his assistance. Neither officers nor soldiers were acquainted with the route, and a negro guide was detailed to lead them. This unique character was Louis Pacheo, a negro slave belonging to an old Spanish family, then living near Fort Brooke. The slave was well acquainted with the Indians, spoke the Seminole tongue fluently. He was reported by his master, as faithful, intelligent and trustworthy, and was perfectly familiar with the route to Fort King.

The affair of Dades' Massacre is without a parallel in the history of Indian warfare. Of the I ro souls, who, with flying flags and sounding bugles merrily responded to General Clinch's order, but two lived to describe in after years the tragic scenes. One was 


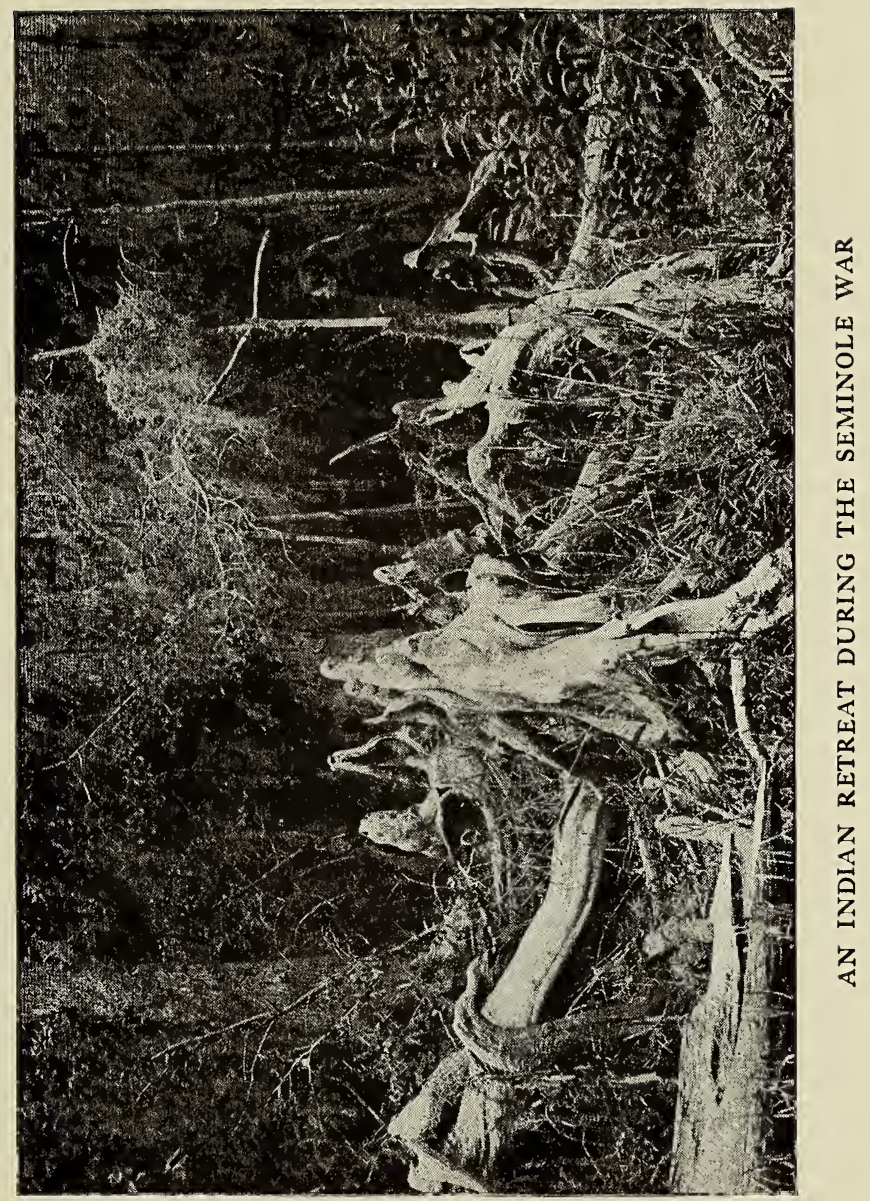



Private Clark, of the 2nd Artillery, who, wounded and sick crawled on his hands and knees a distance of sixty miles to Fort Brooke. The other was Louis Pacheo, the only person of the command who escaped without a wound.

The assault was made shortly after the troops crossed the Withlacoochee river, in a broad expanse of open pine woods, with here and there clumps of palmettoes and tall wire-grass. The Indians are supposed to have out-numbered the command, two to one, and at a given signal, as the troops marched gayly along, a volley of shot was poured into their number. The "gallant Dade" was the first to fall, pierced by a ball from Micanopy's musket, who was the King of the Seminole nation. A breastwork was attempted by the soldiers, but only served as a retreat for a short time; the hot missiles from the Indians soon laid the last man motionless, and the slaughter was at an end.

On February 20, I 836, almost two months after the massacre, the dead bodies of the officers and soldiers were found just as they had fallen on that fatal day. History is corroborated by old settlers, who say " that the dead were in no way pillaged; articles the most esteemed by savages were untouched, their watches were found in their pockets, and money, in silver and gold, was left to decay with its owner a lesson to all the world - a testimony that the Indians were not fighting for plunder! The arms and ammunition were all that had been taken, except the 


\section{8}

\section{THE SEMINOLES OF FLORIDA'}

uniform coat of Major Dade." Their motive was higher and purer; they were fighting for their rights, their homes, their very existence.

What became of the negro guide? History records that Louis, knowing the time and place at which the attack was to be made, separated himself from the troops. As soon as the fire commenced, he joined the Indians and negroes, and lent his efforts in carrying forth the work of death. An account printed over forty years ago describes the character of the negro Louis. It reads as follows:

"The life of the slave Louis is perhaps the most romantic of any man now living. Born and reared a slave, he found time to cultivate his intellect - was fond of reading; and while gentlemen in the House of Representatives were engaged in discussing the value of his bones and sinews, he could probably speak and write more languages with ease and facility than any member of that body. In revenge for the oppression to which he was subjected, he conceived the purpose of sacrificing a regiment of white men, who were engaged in the support of slavery. This object effected, he asserted his own natural right to freedom, joined his brethren, and made bloody war upon the enemies of liberty. For two years he was the steady companion of Coacoochee, or, as he was afterwards called, 'Wild Cat,' who subsequently became the most warlike chief in Florida. They traversed the forests of that territory together, wading through swamps and everglades, groping their way through hommocks, and gliding over prairies. For two years they stood shoulder to shoulder in every battle; shared their victories and defeats together; and, when General Jessup had pledged the faith of the nation that all Indians who would 


\section{THE SEMINOLES OF FLORIDA}

surrender should be protected in the enjoyment of their slaves, Wild Cat appeared at headquarters, followed by Louis, whom he claimed as his property, under slaveholding law, as he said he had captured him at the time of Dade's defeat."

Following Louis Pacheo's career, we find him sharing the fortunes of Wild Cat in the Indian Territory. Subsequently, Wild Cat, with a few followers, Louis among the number, emigrated to Mexico. Fifty-seven years passed from the date of the Dade massacre, when Louis Pacheo, venerable and decrepit, once more appeared on Florida soil. The old negro, longing for the scenes of his youth, returned to end his days in the hospitable home of his "old missus." In his confession, he claims to be innocent of the charge of betraying the troops, and asserts that he was forced into remaining with the Indians. The vagaries of a childish mind may account for his diversion from well-established history. The old slave lived for three years after his return to Florida, and died in January, I895, at the age of 95 years.

\section{A DISHONORED TREATY.}

The tragic news of the Dade Massacre convinced the United States that war had commenced in real earnest. From this time on, skirmish after skirmish ensued, bloody murders were committed by the redskins, thousands of dollars were being expended by: our government, and the white population of Florida was in a suffering condition. The Indians were not 
suffering for food. The chameleon-like character of the war prevented any certainty of success. General Jessup, considerably chagrined, wrote to Washington for permission to resign both the glory and baton of his command.

There could scarcely arise a more painful theme, or one presenting a stranger variety of aspects, as it whirled scathing and bloodily along, than did the Indian War. Yet it is a remarkable fact that no Seminole warrior had ever surrendered, even to superior numbers. Our military forces had learned what a hydra-headed monster the war really was, and attempts were again made to induce emigration. The horrors of the Dade Massacre and of Fort King had reached the world. General Jessup sought negotiations, but found the same difficulties to encounter as before, viz.: that the chiefs would not enter into an agreement that did not guarantee equal rights to their allies as to the Indians. Official documents show that General Jessup agreed that " the Seminoles and their allies who come in and emigrate West, shall be secure in their lives and property; that their negroes, their bona fide property, shall accompany them West, and that their cattle and ponies shall be paid for by the United States." The Indians, under these terms, now prepared to emigrate. History. records that even Osceola avowed his intention to accompany them. Every preparation was made to emigrate, and a tract of land near Tampa was selected on which to gather their people. Hundreds of Indians and negroes encamped there. Vessels 


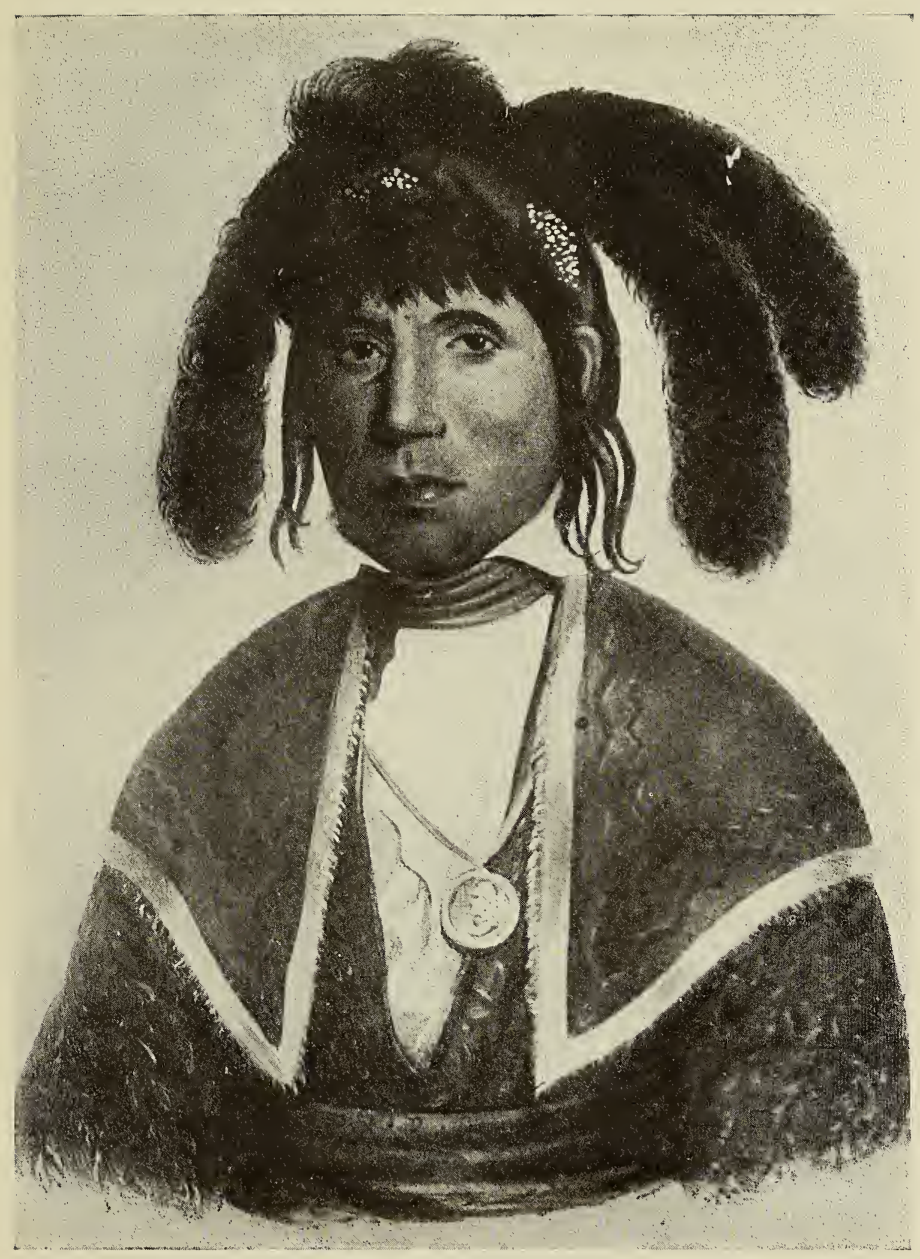

Courtesy of the Bureau of American Etlinology. MICANOPEE - HE WAS THE KING OF THE NATION 

were anchored to transport them to their new homes. Peace was apparent everywhere, and the war declared at an end. At this point a new difficulty arose. Slave-holders became indignant at the stipulations of the treaty, and once more commenced to seize negroes. The Seminoles, thinking themselves betrayed, with clear conceptions of justice, fled to their former fastnesses in the interior, and once more determined to defend their liberty.

In the violation of the treaty, to use General Jessup's words, all was lost!

All the vengeance of the Indian was again aroused, and the wild Seminole war-cry, "Yohoehee! yohoehee," again broke through the woods.

AS-SE-HE-HO-LAR, THE RISING SUN, OR OSCEOLA.

The fame of Osceola now reached the farthermost corner of the land. His name, signifying Rising Sun, ${ }^{1}$ seemed prophetic, and he became at once the warrior of the Ocklawaha, the hero of the Seminoles. The youngest of the chiefs, he possessed a magnetism that Cyrus might have envied, and in a manner truly majestic led his warriors where he chose.

In the personal reminiscences of an old Florida settler, in describing Osceola, he says, "I consider him one of the greatest men this country ever

${ }^{1}$ Catlin and others give "the black drink" as the signification of Osceola, or Asseola, from the man's capacity for that drink. Asseola was doubtless the original and true name. But "Asse" or "hasse," in the present Seminole tongue, means "the sun." This, with the affix "ola," or "he-ho-lar," would mean "the rising sun" rather than "the black drink." 
produced. He was a great man, and a curious one, too; but few people know him well enough to appreciate his worth. I was raised within ten miles of his home, and it was he who gave me my first lessons in woodcraft. He was a brave and generous foe, and always protected women and children. An act of kindness was never forgotten by him. Osceola had received a favor from one of the officers who led the battle of the Withlacoochee. Observing him in the front ranks, he instantly gave orders that this man should be spared, but every other officer should be cut down. Osceola's father was an English trader named Powell, and his mother the daughter of a chief known as Sallie Marie, a woman very small in stature, and with high cheekbones. Osceola lacked this peculiarity, and was one of the finestlooking men I ever saw. His carriage was erect and lofty, his motion quick, and he had an air of hauteur in his countenance which arose from his elevated pride of soul. His winning smile and wonderful eyes drew from an army officer these glowing words of admiration, "But the eye, that herald of the Soul, was in itself constituted to command. Under excitement it flashed firm and stern resolve; when in smiling it warmed the very heart of the beholder with its beams of kindness. I tell you, he was a great man; education would have made him the equal of Napoleon. He hated slavery as only such a nature as his could hate. He was Indian to the heart, and proud of his ancestry. He had too much white blood in him to yield to the cowardly offers of the 
government, and had he not been captured, the Seminole War would have been a more lasting one than it was. I could talk all day about Osceola," remarked the old Captain, as he drew a sigh. "Did the Indians take scalps, Captain?" "Take scalps? Well, yes, if Osceola wasn't around. He was too much of a white man to allow it himself."

The admixture of Caucasian blood stimulated the ambition of Osceola's Indian nature; his education, together with the teachings of nature, made him able to cope with the most learned. Living until he was almost twelve years of age in the Creek confederacy of Georgia, his youthful mind received deep and lasting impressions from Tecumseh's teachings. To these teachings, as well as the blood he inherited from his Spartan ancestors was due, no doubt, his supremacy in the Seminole War. In the manner in which he led the Seminoles may be seen the influence of the great Shawnee. ${ }^{1}$ Osceola's power was in his strong personal magnetism; he swayed his warriors with a look; a shout of command produced an electric effect upon all. He was a hero among his people, he was feared and dreaded by our officers. In this day, as we study his life and character, we must recognize in the young Seminole fighter the greatest of chiefs, the boldest of warriors. In an old Greek fable, a man seeks to prove the superiority of his race by reading to a lion accounts of various

1 As a glimpse into Indian character, it is worth recalling that Tecumseh, the Shawnee Chief, rose to the distinction of a Brigadier General in the British Army under King George III, in the War of I8I2. 


\section{THE SEMINOLES OF FLORIDA}

battles between men and beasts, to which the lion replied, "Ah, had we written that book other tales would have been told." In the case of the Indian chieftain no such records exist, yet even from the testimony of his enemies we must know Osceola.

Interviewing old settlers who well remember events of those stirring times, one finds the heroic part of Osceola's character to have been not overdrawn in history. The Seminole chief, Charles Omatla, was an ally of the whites, and was attacked and murdered by Osceola's warriors. On his body was found gold, which Osceola forbade his men to touch, but with his own hands he threw the gold himself as far as he could hurl it, saying, "it is the price of the red man's blood."

Osceola's pride was majestic; he was imperious, full of honor, but with the quickness of the Indian he noted the path to popular favor. His power was recognized by the officers. "Talk after talk," with the Indians was the order of the times. It was at one of these meetings that Osceola in the presence of the commissioners attracted attention by saying, "This is the only treaty I will ever make with the whites," at the same time drawing his knife and striking it into the table before him. The cause of this outburst was that the stipulations of the treaty guaranteed no protection to the allies. He was arrested for his insolence, but was released on a compromise. His vengeance became more terrible than ever, and in defiance "Yohoehee" echoed through the woods and "war to the knife" was resumed. 


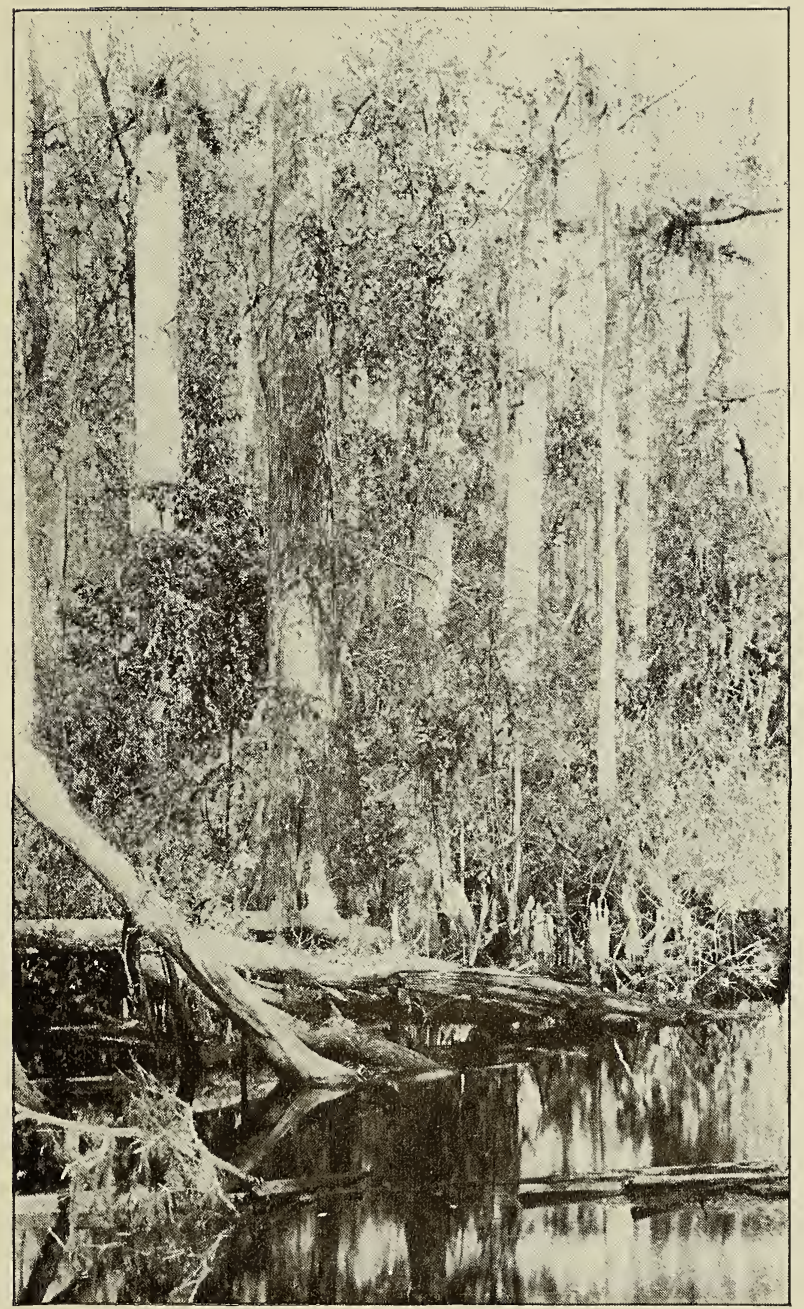

ONE OF THE LAST SEMINOLE BATTLE GROUNDS 

It was now that the daring chief made the bold and well-conducted assault against the fort at Micanopy. A short time after, this savage hero performed a piece of strategy before unheard of in the annals of war. Surrounded by two armies of equal strength with his own, he carried away his warriors without leaving a trace of his retreat. That host of Indian braves melted out of sight as if by magic, and our disappointed generals could not but agree that a disciplined army was not adapted to the work of surprising Indians. They were learning to recognize the character of the men our nation had to deal with.

The Indian method is to decoy by a broad plain trail, then at a certain distance the foremost of the band makes a high, long step, leaves the trail and, alighting on the tip of his toe, carefully smoothes out the brushed blades behind him. The rest of the band go on a few yards farther and make their exit the same way, and so on till the end is reached. Many times our troops made long night marches to find - what? Nothing but a few smouldering camp fires.

The war raged on in defiance of the power of a mighty nation, a nation that had said to old King George, "attend to your own affairs" and he obeyed.

What shall we say of the capture of the great Indian chief. Is not the seizure of Osceola America's blackest chapter? Was Osceola treacherous? The United States failed to observe even one important article of the three treaties made with the 


\section{THE SEMINOLES OF FLORIDA}

Seminoles. Was Osceola a savage? It is not denied that he protected women and children when he could. It is not denied that the soldiers of the United States shot down women and children, destroyed all dwellings, crops and fruit trees they could reach.

\section{OSCEOLA'S CAPTURE.}

After months of warfare, a conference among the Indians with a view to a treaty of peace was held. An Indian chief was sent to the American quarters.

Picture, if you will, an American camp, in the wooded wilds of Florida, and peer beyond the confines of the magnolia and the palms and you see a single Seminole chieftan, heralding his white flag. $\mathrm{He}$ approaches our General, the representative of proud and free America, and presents him with a. white plume plucked from the egret, with a message from Osceola, with these words, "the path shall be white and safe from the great white chieftain's camp to the lodge of Osceola."

General Hernandez immediately despatched Coacoochee with a pipe of peace, kindly messages and presents.

What was the result? Osceola, in company with Wild Cat and other chiefs, accepted the truce and, under the sacred emblem of the white flag, met General Hernandez on October 2 I, I837 at St. Augustine.

With that grave dignity characteristic of the red man, dressed in costume becoming their station, with as courtly a bearing as ever graced Kings, 
heralding their white flags they approached the place of meeting.

History verifies the Seminole account of this blot on our nation that, as the officers approached, they asked of Osceola: "Are you prepared to deliver up the negroes taken from the citizens? Why have you not surrendered them as promised by your chief Cohadjo?"

According to history, this promise had been made by a sub-chief and without the consent of the tribe. A signal, preconcerted, was at this moment given and armed soldiers rushed in and made prisoners of the chiefs.

An account of this violated honor, recently given by the venerable John S. Masters, of St. Augustine, Florida, is opportune at this point. The old soldier in speaking of the affair said, "I was one of the party sent out to meet Osceola when he was coming to St. Augustine under a flag of truce." "Did you honor that truce?" was asked. "Did we? No sir; no sooner was he safe within our lines than the order to seize him, kill if necessary, was given, and one of the soldiers knocked him down with the butt of his musket. He was then bound and we brought him to Fort Marion and he was put in the dungeon. We were all outraged by the cowardly way he was betrayed into being captured."

At this violation of the sanctity of the white flag our officers wrote: "The end justifies the means; they have made fools of us too often."

The foul means used to capture the young Semin- 
ole leader was not blessed by victory, as a continuance of the bloody war for five years proved that the God of justice was not wholly on the white man's side. The stain on our national honor will last as long as we have a history. Osceola with the other chiefs was confined for a short time in St. Augustine, but the daring savage was too valuable a prize to trust on Florida territory, and he was taken to Fort Moultrie where he died January 30, I 838 , at the age of thirty-four years.

It is related that Osceola on being questioned as to why he did not make his escape, as did some of the other chiefs from Fort Marion, replied, "I have done nothing to be ashamed of; it is for those to feel shame who entrapped me." Chas. H. Coe, in his Red Patriots says, "If the painter of the worldfamed picture, Christ before Pilate, should seek in American history a subject worthy of his brush, we should commend to him, Osceola, before General Jessup. Osceola, the despised Seminole, a captive and in chains; Jessup, in all the pomp and circumstances of an American Major-General; Osceola, who had "done nothing to be ashamed of," calmly confronting his captor, who cowers under the steady gaze of a brave and honorable man!"

But such is the Irony of Fate. Osceola, the free son of the forest, fettered by the chains of Injustice, was destined to eat out his heart in a musty dungeon.

Thoroughly and thrillingly dramatic was the death scene of the noble Osceola as given by Dr. Weedon 
his attending surgeon. Confinement no doubt hastened his death, and his proud spirit sank under the doom of prison life. He seemed to feel the approach of death, and about half an hour before the summons came he signified by signs - he could not speak - that he wished to see the chiefs and officers of the post. Making known that he wished his full dress, which he wore in time of war, it was brought him, and rising from his bed he dressed himself in the insignia of a chief. Exhausted by these efforts the swelling heart of the tempest-tossed frame subsided into stillest melancholy. With the death sweat already upon his brow, Osceola lay down a few minutes to recover his strength. Then, rising as before, with gloom dispelled, and a face agleam with smiles, the young warrior reached forth his hand and in dead silence bade each and all the officers and chiefs a last farewell. By his couch knelt his two wives and his little children. With the same oppressive silence he tenderly shook hands with these loved ones. Then signifying his wish to be lowered on his bed, with slow hand he drew from his war belt his scalping knife which he firmly grasped in his right hand, laying it across the other on his breast. In another moment he smiled away his last breath, without a struggle or a groan. In that death chamber there was not one tearless eye. Friends and foes alike wept over the dying chief. Osdeola died as he lived - a hero among men.

OSCEOLA - PATRIOT AND WARRIOR, DIED, JAN. 30,- 1838 . 
Such is the inscription, that marks the grave of the hero of the Seminoles.

Even at this writing, it is a melancholy satisfaction to know that the great Indian leader was buried with the honor and respect due so worthy a foe.

A detachment of the United States troops followed by the medical men and many private citizens, together with all the chiefs, and warriors, women and children of the garrison in a body, escorted the remains to the grave, which was located near the entrance to Fort Moultrie, Charleston Harbor. A military salute was fired over the grave and as the sound reverberated over the dark waters of the bay, Justice and Patriotism, must have pointed with fingers of scorn to our great Nation, yet with tender pity, said "Osceola - the Rising Sun, may the Great Spirit avenge you, keep you, love you and cherish you,- the Defender of your country."

\section{THE HIDDEN WAR CAMP.}

WILD CAT and Cohadjo were allowed to remain in old Fort Marion the prison at St. Augustine, Florida. Wild Cat feigned sickness and was permitted, under guard, to go to the woods to obtain some roots; with these he reduced his size until he was able to crawl through an aperture that admitted light into the cell. Letting himself down by ropes made of the bedding, a distance of fifty feet, he made his escape, joined his tribe and once more rallied his forces against our army. Latter day 


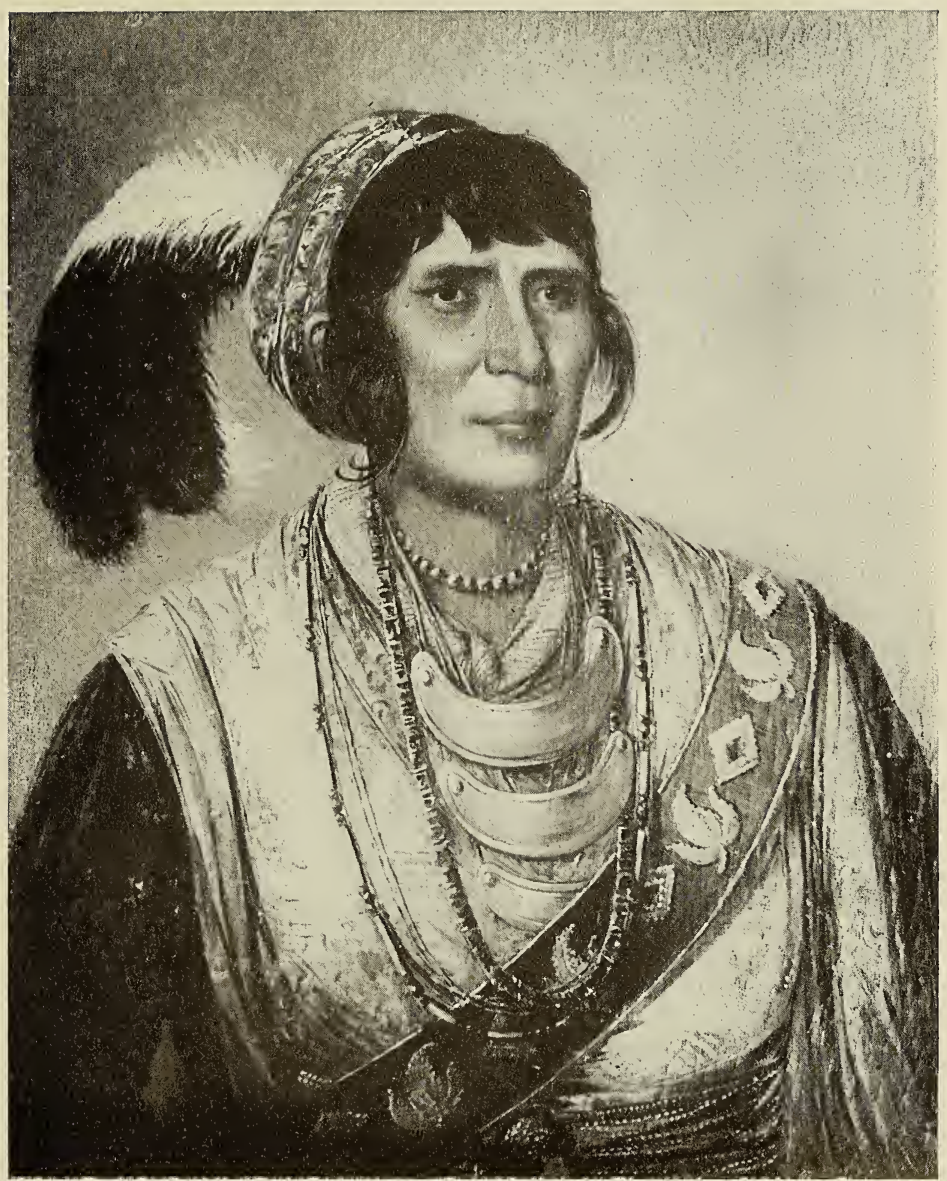

Courtesy of the Burean of American Ethnology.

OSCEOLA

A copy from Catlin's painting. 



\section{THE SEMINOLES OF FLORIDA $3^{r}$}

critics have questioned the correctness of this bit of written history. Last winter, during the height of the season, the Ponce de Leon guests enjoyed a unique entertainment. A wealthy tourist made a wager of one hundred dollars that "Wild Cat never could have made his escape through the little window in the old castle." Sergeant Brown accepted the wager and himself performed the feat, to the great delight of the excited spectators.

Our soldiers fighting in an unexplored wilderness, along the dark borders of swamp and morass, crawl- ing many times on hands and kness through the tangled matted underbrush, fighting these children of the forest who knew every inch of their ground could hope for little less than defeat. Even General Jessup in writing to the President said: "We are attempting to remove the Indians when they are not in the way of the white settlers, and when the greater portion of the country is an unexplored wilderness, of the interior of which we are as ignorant as of the interior of China."

By way of illustrating the enormity of the task the government had in subduing the Seminoles, it is only necessary to describe one of the many Indian strongholds in the swamps of Florida. About ten miles from Kissimmee, west by south, is a cypress swamp made by the junction of the Davenport, Reedy and Bonnett creeks. It is an acquatic jungle, full of fallen trees, brush, vines and tangled undergrowth, all darkened by the dense shadows of the tall cypress trees. The surface is covered with water, which, from ap- 
pearance may be any depth, from six inches to six feet; this infested with alligators and moccasins would have been an unsurmountable barrier to the white troops.

A few years ago when the Seminoles yet frequented this section for trading purposes old settlers have seen them coming from the swamp carrying bags of oranges. Interrogations received no answers and white settlers year after year searched for the traditional orange grove, but without success.

So difficult to penetrate and so dangerous to explore is the swamp that is was not until fifty years after the Indians had left their island home that a venturesome hunter, during a very dry season, accidentally discovered the old Seminole camp. The Indian mound, the broken pottery and the long hunted for sweet orange grove were proofs of the old camp. The majestic orange trees laden with golden fruit were an incentive to further research. With a surveyor working his way, as guided by the point of the compass, this wonderland was explored, and proved to be a complete chain of small hommocks or islands running through from one side of the swamp to the other; the topography of the marsh being such that a skirmish could take place on one side of the jungle and an hour later, by means of the secret route through the swamp, the Indians could be ready for an attack on the other side, while for the troops to reach the same point, by following the only road known to them, it would have required nearly a day's marching. The Indian trail is lost in the almost impene- 
trable jungle; but the tomahawk blazes are perfectly discernible. The Seminoles held the key to these mysterious islands and in the heart of the great swamps they lived free from any danger of surprise. This retreat must have been a grand rendezvous for them, as its geographical position was almost central between the principal forts. Lying between Fort Brooke (Tampa) and Fort King (Ocala), within a distance of thirty miles from the scene of the Dade massacre, about forty miles from Fort Mellon, the present site of Sanford, the camp could have been reached in a few hours by Indian runners after spying the movements of the troops at any of the forts. The old government road, over which the soldiers passed in going from Fort Brooke to Fort Mellon, passes so close to the old Indian camping ground that all travel could have been watched by the keeneyed warriors.

\section{WILD CAT AND GENERAL WORTH.}

AT this period of our national history we are unable to picture or appreciate the condition of those slave days, when all blacks of Southern States were regarded as the property of the whites. The fear, the torture, the grief suffered by the negroes and half breeds, who had been a people with the Seminoles almost one hundred years, is beyond our conception. When Indian husbands were separated from wives, selected from the exiles, when children were torn from their homes and carried to slavery, the venge- 


\section{THE SEMINOLES OF FLORIDA}

ance of these persecuted people was constantly alive. Persons of disreputable character-gamblers, horse thieves - were employed as slave catchers and showed no mercy to the helpless victim.

After the violation of the treaty at Tampa, and the capture of Osceola and Wild Cat, under the sacred truce of the white flag, Wild Cat became most daring enemy to the troops, and kept his warriors inspired to the most savage hostilities.

General Scott was now placed in command of the army, yet the same harassing marches continued, and it was not until seven generals had been defeated at the game of Indian warfare by the wily chieftains that any sign of success was apparent.

Our government, discouraged at being unable to conquer the Indians or protect the white settlers, again negotiated for peace, but using a more powerful weapon than in former years, that of moral suasion. Executive documents show that, all through the war, artifice and bad faith were practiced upon the Indians. The government was astonished that a few Indians and their negro allies could defy United States troops. All efforts had failed, even to the horrible policy of employing bloodhounds. To-day we shudder at the barbarity of such an act, but official documents show how much the subject was discussed by Congress and war authorities. A schooner was dispatched to $\mathrm{Cuba}$ and returned with thirty-five bloodhounds - costing the Government one hundred and fifty dollars apiece. They were speedily put upon the scent of Indian scouting parties, 
but proved utterly inefficient. The public believed the hounds were to trail Indians, but reports show their use was to capture negro slaves. The Seminoles were a species of game to which Cuban hounds were unaccustomed and they refused to form acquaintance with the new and strange objects. The Indians had a secret peculiarly their own of throwing the dogs off the scent, and the experiment, to close the war thus, proved a failure and served no other purpose than to reflect dishonor on our nation.

Wild Cat, after his escape from prison, was a terrible and unrelenting foe. Occupying with light canoes the miry, shallow creeks, and matted brakes upon their border, he was unapproachable. A flag was sent him by General Worth, but, remembering well another flag which had meant betrayal, capture and chains, the daring hero fired upon it and refused to meet the general. In the summer of I $84 \mathrm{I}$, General Worth's command captured the little daughter of Wild Cat and held her for ransom. The little girl,- his only child - was the idol of the old warrior's heart. On learning of her capture, Wild Cat relented, and, once more guarded by the white flag, was conveyed to General Worth's camp. History gives an interesting acount of the old chief's approach. His little daughter, on seeing him, ran to meet him, presenting him with musket balls and powder, which she had in some way obtained from the soldiers. So much overcome was the fearless savage on meeting his child that the dignified bear- 
ing so carefully practiced by all Indians gave way to the most tender emotions.

The moral suasion, the humanity of General Worth made a friend of Wild Cat, and he yielded to the stipulations.

The speech of the old chieftain, because it breathes the same sentiment of the Seminoles of to-day, we give below. Addressing General Worth, he said:

"The whites dealt unjustly with me. I came to them when they deceived me. I loved the land I was upon. My body is made of its sands. The Great Spirit gave me legs to walk over it, eyes to see it, hands to aid myself, a head with which I think. The sun which shines warm and bright brings forth our crops, and the moon brings back spirits of our warriors, our fathers, our wives, and our children. The white man comes, he grows pale and sickly; why can we not live in peace? They steal our horses and cattle, cheat us and take our lands. They may shoot us, chain our hands and feet, but the red man's heart will be free. I have come to you in peace, and have taken you by the hand. I will sleep in your camp, though your soldiers stand around me thick as pine trees. I am done. When we know each other better, I will say more."

Through the gentleness and humanity of the "gallant Worth," Wild Cat at this meeting agreed to emigrate with his people. He was permitted to leave the camp for this purpose. By some contradictory order, while on his way to his warriors, he was cap- 
tured by one of our commands, put in chains and transported to New Orleans.

When General Worth learned of this violation of his pledge he felt the honor of our country had again been betrayed, and acting on his own discretion sent a trusty officer to New Orleans for the return of Wild Cat. General Worth by this act not only showed the nobility of his own character, but proved that the savage heart can be touched with kindness and is always keenly alive to honor and faithful pledges. Moreover the justice of the act had much to do with the successful turning of the war.

When the ship which brought the chief reached Tampa General Worth was there to meet it and publicly apologized to the brave old warrior for the mistake that had been made. Our gallant commander had proven his humane heart, although at expense of both time and money. Through the policy of General Worth, the whole character of the war was changed. On the 3 Ist of July, I 84I, Wild Cat's entire band was encamped at Tampa, ready to be transported to their new homes.

The original idea of re-enslaving the fugitives was abandoned. General Worth and Wild Cat now became the most ardent friends, the general consulting with the famous chieftain until every arrangement for the removal was perfected. Seeing a chief of such prominence yield to emigration, band after band gave up the fight and joined their friends at Tampa. From the time of Wild Cat's removal in 


\section{THE SEMINOLES OF FLORIDA}

the fall of I 84I, until August, I 843, small bands of Indians continued to emigrate. General Worth now advised the withdrawal of the troops. A few small bands throughout the State refused to move, signed terms of peace, however, by which they were to confine themselves "to the southern portion of the Peninsula and abstain from all acts of aggression upon their white neighbors." As vessel after vessel anchored in Tampa Bay to carry these wronged and persecuted people to their distant homes, the cruelty of the undertaking was apparent to the most callous heart. With lingering looks the Seminoles saw the loved scenes of their childhood fade away. The wails and anguish of those heart-broken people, as the ships left the shores, touched the hearts of the most hardened sailor. They were leaving the graves of their fathers, their happy hunting grounds, beautiful flowery Florida. But it is the destiny of the Indian. Among that band there was not one voluntary exile. Poets and artists picture the gloom, the breaking hearts of the French leaving Acadia; at a later day the same sad scenes were witnessed on the Florida coast, but it was not until years after that a philanthropist gave to the world an intimation of the melancholy picture of these poor struggling, long hunted Seminoles leaving the shores of their native lands.

\section{INDIAN WARFARE.}

There is something intensely sad in the history of the Indians who were left in Florida at the close 
of the "seven years' war." Keeping faith with their promise to abstain from all aggression on their white neighbors, retiring to the uninhabited marshes of the Southern Peninsula, they lived happy and contented for thirteen years. Then came reports of outbreaks and the United States again opened military tactics with the resolve to drive this brave and liberty loving remnant from their last foothold on Florida soil.

According to the most authentic reports, the trouble was brought on by some white engineers encamped near the border of the Big Cypress. It was in the year 1855 and the United States was making a general survey of Florida. Old Billy Bowlegs, recognized as the head of his tribe, and living at , peace with all the world, had a fine garden in this swamp and in it were some magnificent banana plants, which were the delight of the old Indian's heart.

As the old warrior visited his garden early one morning, he discovered some ruthless hand had ruined his garden. They were deliberately cut and torn to pieces. Going to the engineers' camp, he accused the men of the outrage, when they insolently admitted it, refusing to make amends, and saying that they wanted to "see old Billy cut up." And they did!

The government paid for it to the extent of several thousand dollars, a number of lives and adding another dark page in the history of our Nation. No white man would have submitted to the out- 
rage, neither did the famous Chief. Summoning his braves early the next morning, the war cry "Yoho-ee-hee," was heard and Lieutenant Hartsuff and his men were fired upon, some of them being wounded.

Like a flash of electricity the news encircled Florida, and Billy Bowlegs became the target of many old muskets.

Then came the clamor of white settlers for the removal of the "savages" and white guerrillas dressed and painted as Indians went about the country robbing and murdering mail and express riders, driving off stock, burning houses and committing other lawless deeds. Old inhabitants tell of these depredations. But there was a reason for such cowardly acts. The Government at Washington was perplexed and, not grasping the fact that the raids were perpetrated by white men, disguised as Indians, believing that military forces could do nothing towards breaking up the warfare, designed the plan of offering the sum of $\$ 100$ to $\$ 500$ for living Indians delivered at Fort Brooke (Tampa) or at Fort Myers. After Govermental hunting for three years, the white guerrillas still busy with their malicious depredations, Old Billy Bowlegs, with his band of one hundred and fifty persons, was induced to emigrate, but they went with sore unwillingless, silent or weeping towards the land of the setting sun, driven before the power of the white man, a group of broken-hearted exiles. 
Dat Seminole Treaty Dinner 



\section{INTERLUDE}

\section{DAT SEMINOLE TREATY DINNER.}

THE author begs the indulgence of the reader in giving the following dialect story of that historic Treaty Dinner, when our gallant American General Worth made peace terms with the Indians in 1842 .

The treaty was signed at Fort King, now the present site of Ocala, Florida, and as one listens to the story of that eventful day, a story complete in its setting as told by our old Bandanna Mammy, the hearts throbs and the pulse grows quicker - so vivid is the recital.

As the tale is related a most picturesque scene comes before the mind, the garrison with its stack of arms, dusky warriors mingling with American soldiery, glittering sunshine and singing birds, tables spread under the great live oaks, joy on every countenance - the end of the Seven Years' War. Because this old ante-bellum slave is a bright link, forging as it were, those olden days of warfare with the present, a few words of her individuality must interest.

Martha Jane, for so she was christened full ninetyfive years ago when, a little shining black pickaninny, her birth was announced to the mistress of the old Carter plantation, is the true type of the old time loyal, quaintly courteous Bandanna Mammy of antebellum days. Leaving Richmond about I 839, she 


\section{THE SEMINOLES OF FLORIDA}

was brought to Florida with a shipload of slaves. Since that time her life has been a rugged and an eventful one - a servant for the wealthy, nursing the sick, sold again and again, hired out, and, since freedom, working for her daily bread.

This white haired relic of Old Virginia is worthy a place in the pages of history. She is old, decrepit and poor, the muscles of her once powerful arms are shrunken and her hands gnarled with the labor of years, but she has a memory as keen as when almost 80 years ago she watched the "stars fall" from the upper windows of the Old Swan Hotel in Richmond. She has kept pace with many points in history, particularly of the wars of the country.

As the old dame - a study in ebony - rocks back and forth in the creaking split-bottom chair, memory runs back to the imperial days of Virginia when the cavalier was supreme, and she the pampered nurse girl of the little mistress. She says, "Oh, dem was dream days. I hab nebber seed any days like 'em since. De mounfulest day I ebber seed was when dey took me from my mistress, for the sky was a drippin' tears and de wind was a groanin'."

"No, honey, dey ain't stories 'bout dem Seminole war days, dey is de Lord's blessed truf, what ole Marthy see wif dese same ole eyes.

"Oh, dem wuz high times! I reckelmember dat Krismas day jest like hit wuz yisterday; the sun wuz a shinin' an' de birds a singin' (you see, de mokin' birds didn't sing while dat cruel war wuz a goin' on) an' ebbery body wuz a laughin' an' a talkin' an' de, 


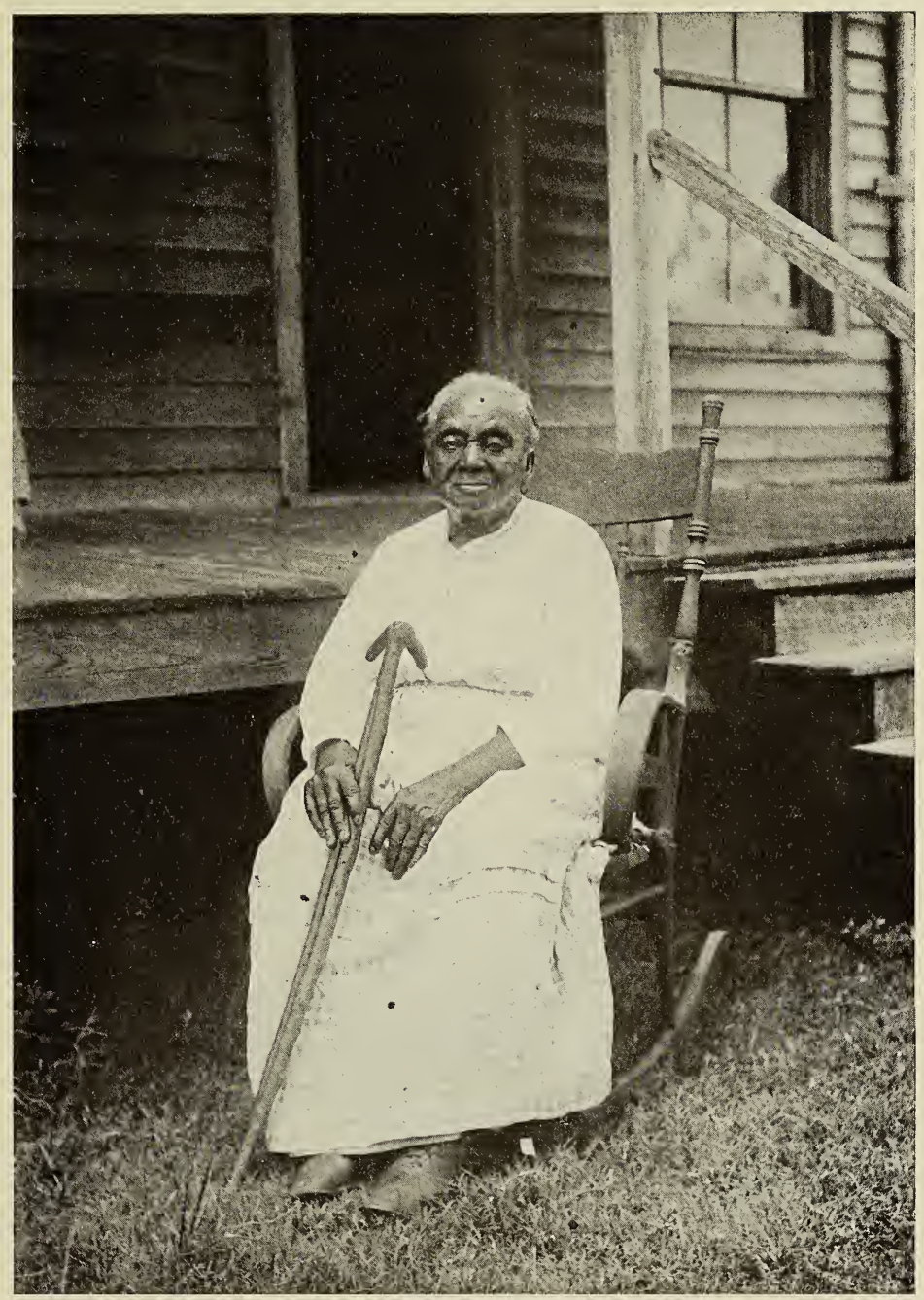

MARTHA JANE, “ BANDANNA MAMMY"

who cooked the Treaty dinner for General Worth in I842. Now living in Kissimmee. 

white ladies wuz a coquettin' wif de sojers an' dem Indians wuz as thick as hops an a laughin' an' a jabberin' too.

"When Colonel Worth see dem long tables settin' under the big live oaks an' see dem beeves an' muttons an' turkeys an' deer we cooked, he jest natchelly laughed an' say, 'Clar ter goodness, what kin' o' Krismas doin's is dis'; an' how dem sojers an' Indians did eat.

"How come I ter cook de treaty dinner?

"Well, I wuz livin' out on ole Marse Watterson' plantation, 'bout four miles from Fort King, dats to Ocala, now, you know, an' Jim, dat wuz Colonel Worth's servant, he ride out on dat big white horse o' de Colonel's an' say 'Colonel Worth want Marthy Jane ter cook de treaty dinner;' so me an' Diana Pyles an' Lucinda Pyles cook dat dinner.

“ Oh, Lordy, what scufflin' roun' an' jumpin' like chickens wif der heads off as we do dat day.

“ All de sojers' guns an' de Indians' guns, too, wuz stacked in dat garrison, an' when de night come, dey make big camp fires an' de white folks dance an' de Indians wuz a dancin' too, wif dem ole coutre (terrapin) shells a strapped 'roun' der legs.

"Tell you 'bout Colonel Worth? He wuz de gem'men ob all dat crowd; he wuz de nobles' lookin' man an' so kind an' easy; de United States nebber would hab conquered dem Seminoles if dey had not induced Colonel Worth ter come down an' argufy wif dem. Him an' old Captain Holmes wuz de mos' like our folks ob any ob dem big generals. 


\section{THE SEMINOLES OF FLORIDA}

"Arter dey had all eat, an' eat dem fine wituals we cook, den dey hab de speech makin'; oh, dat wuz high 'stronomy talk!

"I reckelmember jest like hit wuz to-day, me an' Diana Pyles wuz a standin' right inside de garrison an' dat noble-lookin' Colonel Worth wuz talkin' kind an' persuadin' like ter dem savages an' axin' dem all ter come up an' sign de treaty.

"You see dat treaty wuz foh dem ter quit fightin' an' go ter Arkansas.

"All dem chiefs walk up but two. Oh, Lordy mercy I kin jest see dat Sam Jones yit standin' close 'side Colonel Worth. He wuz sut'n'ty a big Indian an' could talk English good as we alls white folks.

"He jest look at de Colonel pizen like an' I smell de trouble den, an' he up an' say, 'My mother died heah, my father died heah, an' be demned I die heah; yo-ho-ee, hee-ee!'

"How dat Indian could gib dat war whoop; an' he walk right ober yonder ter dat big stack ob guns an' take his rifle an' ebbery Indian ob his band follow' 'm an' dey walk out ob dat garrison as easy as a cat arter a mouse.

"Colonel Worth did look so peaked, but twan't no use, foh he couldn't stop dese chiefs; he hab gib dem the promise dat if dey, would all come in he would treat 'em all right.

"Dem wuz cruel days," and old Martha Jane quivered with indignation as she brought her fat hand down upon her knee. "But hit wasn't de Indians' fault. No man what hab a gun is gwine ter let 
somebody steal the cattle an' horses, an' dat jest what de white people do ter de Seminoles.

"Lord a mercy, I hab seed Paynes' Prairie covered wif de cattle an' horses dat 'longed ter de Indians, an' de white raspcallions would carry 'em off a hundred at a time. Umph! I heah 'em brag how dey carry off de Indians' horses. Ole Thorpe Roberts he wuz a ole fief. He would say, 'We make many a good haul ob dem savages' cattle, ten ob us come in at onct an' drive off a thousan' head.'

"Yes, Mistis, dat ole Seminole war make a heap o' white folks rich in Florida.

"Oh, Lord hab mercy on all dem souls. Dey. wuz hard times, times o' misery, chile, but de Indians wuzn't ter blame. God make 'em an' dey hab ter hab a place ter stay, jest same as we alls white folks.

"De white people bring all dat 'struction on der own heads foh dey commence dat war. I see hit wif my own eyes; I see 'em kill de Indians' slaves. You see de Seminoles hab slaves jest de same as white folks, an' some ob der niggers wuz as fine-lookin' black men as you ebber 'spect ter see in Ole Virginia.

"When de Indians would come 'roun' ter esquire 'bout der cattle de white rapscallions (an' a heap o' dem wuz dem low down nigger traders too) dem white men would up an' shoot de Indians.

"Lordy chile, when I gits ter ruminatin' 'bout dem days I sees de longes' line o' haunts whats obtained in dis world o' sin an' sorrow."

I laid down my tablet and looked up; the old wom- 


\section{THE SEMINOLES OF FLORIDA}

an's lip was quivering from suppressed emotion. Passing over the tragic she began again.

“No, chile, 'xcusin' ob de truf, de United States nebber whipped de Seminoles; she whipped dem Britishers when George Washington wuz de captain, an' de Mexicans, den she tuck a little 'xcursion 'cross ter Cuba an' whipped dem Spaniards; but she nebber whipped the Seminoles. Umph; where wuz de Indians when de sojers wuz all shinin' in dem new uniforms an' der ammunition all packed up? Dem savages wuz all gone, hidin' in dem hammocks an' swamps what wuz so thick wif trees an' bushes dat a black snake could skacely wiggle through.

“ De sojers would go marchin' 'long an' way up in de tops ob some ob dem big trees some ob dem sly ole Indian scouts would be sittin' wifout any clothes on, a watchin' an' a laughin' at de sojers."

"You want ter heah 'bout dat battle o' Micanopy?

"De Seminoles didn't hab no battles like dem Britishers in George Washington times; no chile, but dey hab scrummages an' kill de white people jest like dey wuz black birds," and the old negress, seemingly oblivious to the fact that cruel time has bowed her frame and dimmed the once bright eye, lives over again the story of those days so long ago, when she was the pampared slave of the old aristocracy.

"How come I ter see dat big fight, I b'longed ter Marster Mundane; de Mundane fambly wuz powerful rich and owned the big hotel where the officers wuz stayin'. 
“Der warn't no Indians 'roun' der jest den, an' ebbery thing wuz peaceful an' quiet, an' I heah de sojers a jokin' an' sayin' day wuz jest a spendin' de winter in de Sunny South an' de Governmen' wuz payin' de grub bills.

"I reckelmember jest like I am tellin' you ter day, I wuz standin' on dat big piazza 'side o' Missus; you know I wuz riz up ter be 'roun' white folks, foh I wuz allus so peart dat my ole Missus in Virginia would call me in ter de parlor ter show me off ter de white ladies.

"Well, honey, dis mornin' de sojers wuz a cleanin' der guns an' laughin' an' dey ax Mistis, 'How many deer you want foh dinner?' Den anudder likely young sojer would say, ' How many turkeys you want, Mistress Mundane?' an' den dey went off a whistlin' an' a singin'; but oh, my God, what lamentations der wuz dat same night.

"Twan't long will I heah, bang - bang - bang, an' I says ter myself, Marthy Jane, too many deer, too many wild turkey, sound ter me like Indian shootin'; 'spect dem rapscallions sneak up on de sojers, an' dis black chile gwine ter see foh herself. I jest slipped out o' de house an' kachunk! kachunk! I went down that big lane as fas' as a horse can trot till I come ter de prairie an' den I clumb in ter a big oak tree, den de nex' thing I do I wrap dat gray moss 'roun' me so dem debbils couldn't see me.

"How dem Indians did shoot! If dat sight didn't beat de lan'! Zipp - zipp - bang - bang, an' ebbery time dey shoot dey yell like debbils, yo-ho-e- 
hee-eee bang, den fall on de groun' an' load dat musket, stan' up an' shoot again; de sojers a droppin' ebbery time a Indian shoot.

"De sojers wuz so skeered dey couldn't load der guns when de Indians would gib dat Satan screech.

" An' den de poor sojers jest dropped guns an' run in ter de lake an' de.woods an' dem savages would go an' take de guns an' de ammunition offen de dead bodies an' den go runnin' like a deer.

"Lord a mercy, hit seems ter me I heah de wind blowin' ghosts an' de sperits ob de brave gem'men what wuz killed on dat field ebbery time I talks 'bout dat day.

"Yes, Mistis, dat scrummage wuz called de battle ob Payne's Prairie. When de Colonel found out de Indians killed so many ob de sojers, he tore roun' like a wild bear an' clar 'foh de Almighty dat he wuz gwine ter sen' off an' fetch de whole United States troops ter come down an' kill ebbery Indian in Florida.

"But what good wuz all dat big talk; dey hab two regimen's stayin' der den, and 'foh dey could git outen de garrison de sly ole Indians wuz all gone an' didn't leave a track behin' dem, nuther.

"Dem wuz days ob 'struction, ter be shure! but dey mought ha' knowed dat war wuz a comin', kase Daddy Charles see dem divisions in Virginia an' tell de white people great 'struction ob war wuz a comin', he tell dem dat hit gwine ter wrestle wif a foreign country, an' den 'sides de divisions, de wild pigeons come an' dey wuz so thick you couldn't see de trees 
and de slaves kill 'em wif der hoe handles in de corn field.

"Yes, dat big Seminole war did come," said Martha Jane triumphantly, "jest like dat ole saint o' black man tole de people.

"I ain't nebber seed no lonesomer place like dat Payne's Prairie from dat day ter dis arter dey hab dat skirmishin'.

"I see de folks lyin' on de grass an' de tall grass blowin' backards and forrerds, but dem sojers nebber move. Den de men come an' carry 'em ter de hospital. I shrouded so many dat night dat I got hardened jest like a dog wifout a soul.

"Colonel Whisler, he wuz a Yankee man, he sayd, 'Marthy Jane, you orter hab been a man, you is so nervy.' Dat why I can't eat hominy ter dis day, I make so many poultices endurin' ob de war ter draw out de bullets; dey didn't hab dem pizen balls o' Satan like dey do in dese regenerate days since surrender.

"Arter dem scanlous time, Colonel Worth an' Colonel Whisler 'cided dat dey mus' go ter Fort Myers to see how dem scrummagers wuz goin' on down dat way.

"De headquarter men 'low dey mighty nigh perish'd foh sumptin' good ter eat an' tell ole Mistis dey 'bliged ter hab me go 'long ter do de cookin'. Colonel Whisler wuz one ob dese kind o' captains what want his coffee hot an' all de victuals on de jump.

"Dem wuz high camp-meetin' times all de way. 


\section{THE SEMINOLES OF FLORIDA}

In dem days de game wuz powerful plentiful, an' dem victuals I cooked wuz a plum sight; deer, wild turkey an' ducks wuz a flyin' wherebber der wuz a pond o' water. Um-um-m, didn't I cook 'em de fine victuals.

"Colonel Worth 'cided dey couldn't kill de Indians so he say he would jest campaign along an' destroy all der crops an' burn der houses; he 'lowed dat wuz better dan shootin' dem; an' oh Lordy, didn't we eat de corn an' watermelons dem Indians raise.

“We march an' we stop, an' we march an' we stop, till hit wuz de Lord's blessin' dat we hab so many horses an' wagons.

"Oh, dem long wagon trains, wif sojers betwixt, sojers in front an' sojers behind.

"You see, de officers hab der wives along an' some mighty fine white ladies what wuz a visitin' at de garrison. Dem wuz shure camp-meetin' days.

" Ole Billy Daniels an' old man Strafford, dey wuz along too; dey wuz ole men den. I 'spect dey both dead afoh now."

“I wuzn't anyways skeery, but we sut'n'ty wuz a long way from ole Mistress, mighty nigh two hundred miles.

"Arter all dat camp-meetin' frolickin' Colonel Worth 'cided he would come back ter Fort King an' leave de sojers ter keep on destroyin' at Fort Myers.

"Billy Daniels wuz obliged to 'scort us back, kase he is de man what drawed de map of Florida an' put 


\section{THE SEMINOLES OF FLORIDA 5 I}

all de lakes an' islan's in foh Colonel Worth. $\mathrm{He}$ couldn't read, nuther write, but he could 'cite de Seminole language like he hab book learnin'; he wuz de interpreter foh Colonel Worth too.

" Hit sut'n'ty wuz scrumagen' times arter me an' Diana Pyles cooked dat treaty dinner foh Colonel Worth.

" Mos' generally de troops went a troopin' north, but dey lef' some ob de sassiest white men I ebber see top o' earth ter guard de State; low down white rapscallions.

"You see, hit wuz dis away, terrectly dey fin' out de Indians wuz all gone south dey make up dat dey bes' skeer our people so de United States would keep payin' dem government money.

"No, Mistis, hit wuzn't de Indians dat did de skirmishin,' hit wuz de white rapscallions what wuz hankerin' foh dem government rations.

"Our people wuz rich den wif de big sugar plantations an' cotton fields an' a heap o' slaves an' cattle an' horses; our folks didn't want no war, but hit wuz de poor white people dat rousted 'roun' at night an' kill de cattle an' put moccasins on der ole foots, what look as rough as alligators' hides, den dey go an' make tracks all roun' like a hundred Indians been a spyin'. Hit sholy did skeer our people, but twan't de Seminoles, kase de Indian is a debbil, but he ain't gwine ter stay 'roun' Fort King when he done promise Colonel Worth he gwine go 'way.

"Dem white men keep up dat debbilment till de 


\section{THE SEMINOLES OF FLORIDA}

United States find out 'bout hit, an' she say if dey any moh o' dat meanness foun' out dat dey will hang ebbery rapscallion what prowlin' 'roun' we alls white folks houses." 


\section{PART II}

The Florida Seminoles of To-day 



\section{PART SECOND}

The Present Condition and Attitude of the SEMINOLES

TO-DAY the Seminoles of Florida are a beggared and spectral type of a once powerful race. And in their swamp homes we find these brown-skinned people, living in the primeval customs of their fathers, little changed from the Indians De Soto found in the "Land of Flowers," or Columbus upon the little island upon which he landed the weary and anxious cargo of the frail Pinta, and of whom he wrote to his Queen, "Because they showed much kindliness for us, and because I know they would be more easily made Christians through love than fear, I gave to them some glass beads for their necks, some red caps with which they were so delighted and entirely ours, it was a marvel to see."

Thus we have dispossessed the original owners of as goodly a land as the sun ever shone upon, a land that cost us nothing but the beads of the early adventurers and the bullets of their successors, a race, savages 'tis true, but heroes many of them, and proud and courtly as their conquerors.

The American people expend thousands of dollars annually in scientific research for antiquities and many more thousands are spent by the antiquarian 


\section{THE SEMINOLES OF FLORIDA}

for the preservation of the relics and ancient records. The North American Indian is fast vanishing from the continent. Are not the Seminoles of Florida, the descendants of the old monarchs, this race around which shadowy romance hovers, as worthy of preservation as the inanimate treasures of ancient Egypt? Are there no Rameses in American history? In the old turbaned tribe of Florida, we have a remnant of the most picturesque, deserving and moral of all the Aborigines of America, and they belong to a type that is everywhere else extinct. Are they not worth preserving and protecting to a point worthy the proud and historic name of Seminole?

Secure in the mysterious marshes, these Indians present an eloquent picture of a helpless wandering tribe.

At the close of the war, a few bands of the Indians refused to submit to banishment and, concealing themselves in the fastnesses of the Everglades, made their removal an impossibility. This part of the tribe, according to their traditions, belonged originally to the Aztec race and for this reason they claim a preëminence over all the tribes of Aborigines of America.

Though defeated in war, they never submitted to the Government of the United States, and hence regard themselves as more valiant in defense, more determined in purpose than that part of the tribe which succumbed to emigration to the Indian Territory; in fact, the old chieftains say of the Indians who emigrated, "Arkansas Indians, cowards and traitors." 
So to-day the Seminoles of Florida occupy a unique position with respect to the United States Government, as, being unconquered and unsubdued, having no legal existence nor allegiance to our Nation; in short, so far as the United States is concerned officially, there are no Indians in Florida.

The tribe to-day numbers about 600 souls, living at peace with all mankind, independent, but suspicious of Washington officials, only asking to be let alone, a homeless people in a free land, ever pushing on before the insatiable cupidity of the white man.

An inexorable decree has forced the Florida Indian into the most desolate lands of Florida. Where they once trod as masters they now fear to place foot. We cannot be unmoved by the thought that here are the tattered and poverty stricken handfuls of a tribe of warriors that held at bay a strong government for half a century, a tribe that counted their cattle, their lands and their slaves in magnificent proportions. At the present time, to avoid complications with the South Florida cattle herders none of the race are permitted to own cattle. There is a certain pathos in the Indian's story of his relation to the white race, which arrests our attention and compels sympathy. But, it is destiny! What of the future? Touch any point in the red man's history, where you will, or how you will, and the helpless savage always gets the worst of it.

There is no use in muck-raking about it. We are leisurely taking our time at finishing the extermination of the original American. Whether or not the 


\section{THE SEMINOLES OF FLORIDA}

future historian chronicles this as a century of dishonor, the fact remains that, since he could not withstand the white faces, the Indian will go - pass out of existence.

We judge the Indian too harshly. It is hard to give up old traditions, especially if the adherence to them means a life of ease. We are all in the pursuit of that which will make us happy.

The story is the old one of merciless extinction of the lower race before the higher. It is a story of the "survival of the fittest." The Florida Indian can go no further. An old anecdote is brought to light which illustrates the Indian's own view of the case. The famous Seneca chief, Red Jacket, once met a government agent, and after pleasant greetings they both sat down on a log, when Red Jacket asked the agent to "move along." The agent did so and the chief followed. This was done several times, the agent humoring the whim of the old chief, until he had reached the end of the log, when the same request, "move along" was repeated. "Why, man," angrily replied the agent, "I can't move along further without getting off the log into the mud." "Ugh! Just so white man want Indian to move along - move along; can't go no further, yet he say move along." And so with the Seminole to-day. The clearings they have made in the forests and the only homes they have ever known have been bought from the State by speculators and they are compelled to "move along." The history of the western Indian as he sells or surrenders the heart of his great 
reservation proves that the white man will have his way. The broken treaties of the past the Seminole has not forgotten. The old chiefs are as proud as the most imperious king. They regard these lands as their own, and cannot understand the Government's claim. They say "What right has the big white chief at Washington to give to us what is already ours - the lands of our fathers?" The white man who receives any confidence from the Florida Indian must indeed possess great magnetism, for the Seminole is suspicious of every overture and will mislead his questioner on all occasions. And while the white man is studying "poor Lo," "poor Lo" is similarly engaged in studying him, and continually revolving in his suspicious mind, "what can pale face want from the Indian anyway?"

The chiefs have taught the young braves all about the outrages perpetrated upon their tribe by unscrupulous agents during the wars; and while the Indians themselves in many cases practiced cruelty, it was always in retaliation for some grevious wrong of anterior date. History records case after case of robberies and enormities committed on the Seminoles previous to the war and during its progress. Micanopy requested a lawyer to draw a form of writing for him which soon after proved to be a conveyance of a valuable tract of land! Afterwards the warwhoop and the deadly hand of Micanopy was heard and felt among the swamps and prairies. Micanopy was one of the most powerful, as well as one of the wealthiest Seminole chieftains. His estate, a mile 


\section{THE SEMINOLES OF FLORIDA}

square, he ceded to the United States. Of the disposition of his slaves - he had eighty - nothing is said.

In connection with the portrait of Micanopy as used in this volume, this bit of almost forgotten history is worth mention. When the famous Indian portrait painter, Catlin, was commissioned by the War Department to paint the most prominent chiefs then in captivity at Fort Moultrie, Micanopy, as chief of the Nation, was first approached, but positively refused to be painted. After much persuasion, he at last consented, saying, "If you make a fair likeness of my legs," which he had very tastefully dressed in a handsome pair of red leggins, " you may paint Micanopy for the Great Father," " upon which, I at once began," says Catlin, " as he sat cross legged, by painting them upon the lower part of the canvas, leaving room for the body and head above."

When the chief saw every line and curve brought out on the canvas he smiled his approval, and the work proceeded, to the delight of both artist and subject.

In the mutual relations between the whites and the Indians it requires no skilled advocate to show on which side must lie the wrongs unrepaired and unavenged. Without doubt the Indian has always been the victim. One thing is certain, the Indian chiefs, when fairly dealt with, have always evinced an earnest desire to make just terms. Ever since the Caucasian landed on the shores of America, a white man 
with a gun has been watching the Indian. Four centuries have gone and with them a record of broken treaties and violated pledges. The records of the Indian Bureau support the statement that, before the first half of the present century had passed, we had broken seven solemn treaties with the Creeks, eleven with the Cherokees; the Chickasaws and Choctaws suffered too, saying nothing of smaller tribes. History reveals how well the Delawares fought for us in the Revolutionary War. They were brave "allies," fighting out of loyalty to the "Alliance," and inspired

- by the promised reward, viz.: "The territorial right to a State as large as Pennsylvania and a right to representation in our Congress." But where are the Delawares to-day? One remove after another was made until we find only a remnant existing some with the Cherokees, and a few with the Wichita agency.

A great deal has been written about the Florida Indian which is not in accordance with facts. There are many obstacles in the way of an intimate acquaintance with their customs and home life. Living as they do in the almost inaccessible morasses, their contact with civilization has been regulated by their own volition. Visitors, traders and government agents have been denied their confidence, and it is only on their visits to settlements for the purpose of trading that they meet the white man. At such times the Seminole is on the alert, ever suspicious, and to the numerous interrogations applied to him by the inquisitive stranger, his answer is an indifferent 
"Me don't know." When questions become of a personal character, touching upon subjects sacred to a Seminole, he quietly walks away, leaving his questioner wondering.

The Seminoles live to themselves, shun all intimacy with the Caucasian, and their personal appearance is therefore almost unknown to Americans. The greater part of the tribe seldom, if ever, leave their marshy homes. To reach their camps uninhabitable wilds must be traversed and sometimes miles of mud and water waded, then perhaps only to find the camp deserted. For, while the Seminole has regular settlements, at various times during the year the entire camp will assemble at some point where game is abundant and a "big hunt" will occupy a few weeks. Again syrup boiling will be the festival all will join in; at another time a large quantity of koonti (wild cassava) will be made into flour. At these gatherings the tribe or families occupy temporary dwellings called lodges.

The innate dislike of the Seminole toward strangers is his hardest prejudice to overcome; yet he is hospitable when he convinces himself that the visitor is no Government agent, nor come for any mercenary motive. The person who is fortunate enough to reach their hunting grounds, secure their confidence, observe their weird home life, and their childish untutored ways, meets with an attractive spectacle of romance and may study these aborigines in their primeval customs. For to-day, with the exception of the chiefs and a few of the adventur- 


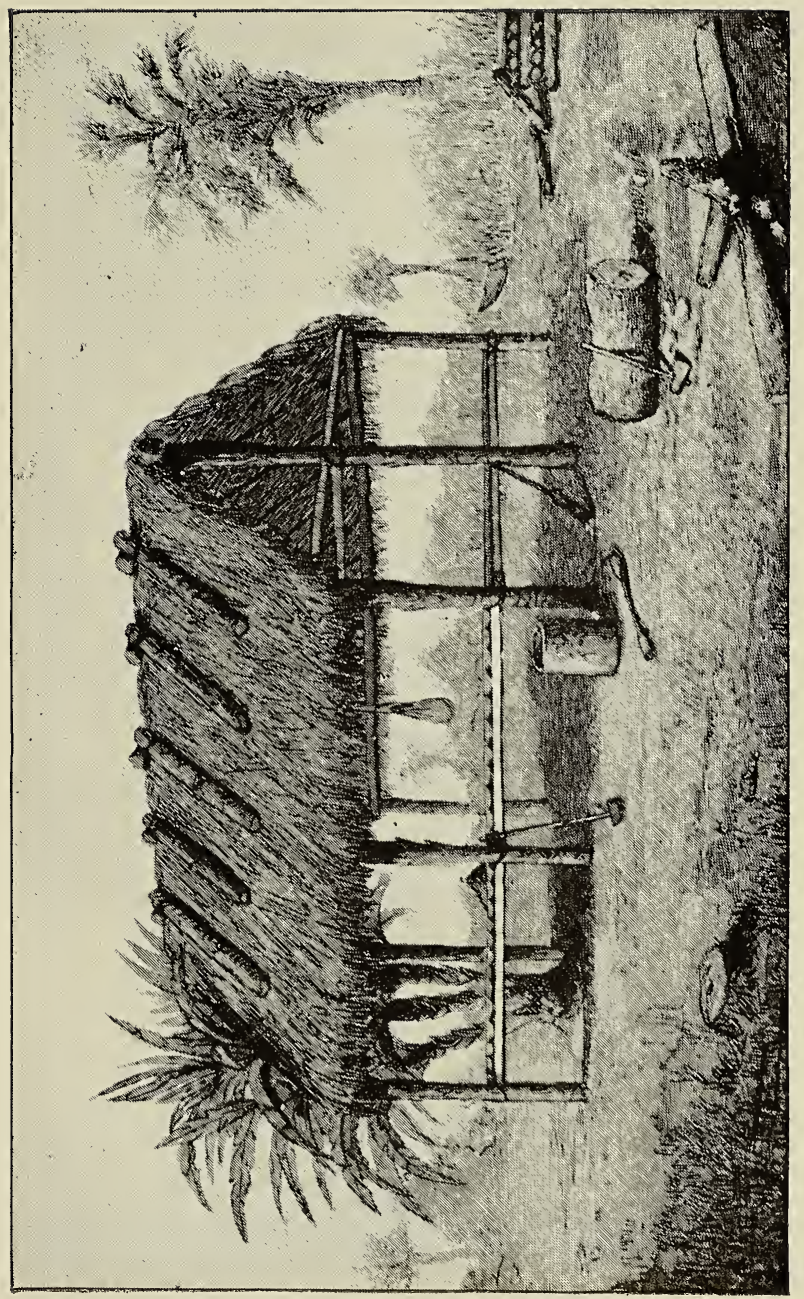

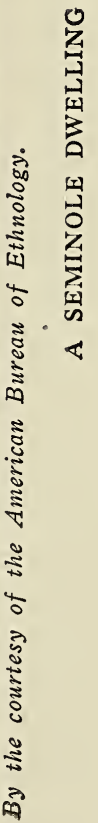



some warriors, they know nothing of the innovations of the last half century. So strong are they in their resolution to hold no intercourse with our nation, that neither bribery nor cajolery will have any effect upon them. A few years ago an effort was made by the authorities of the Sub-Tropical Exposition at Jacksonville, Florida, to secure a few of the Seminole braves for exhibition. After many proffered bribes, the young warriors with the adventurous spirit of youth consented to go to the " big city." A council was held and the chiefs said "halruk (it is bad); if you go you never come back." The council of the chiefs is always respected and the young braves remained with their fathers.

The life of the Seminole has been without any aid or instruction from the white man. He has adopted a few of the implements, weapons and utensils of civilization; but in no other way has he imitated his pale-faced brother. In the natural course of evolution he has made some progress; he has not degenerated.

Government reports show an annual appropriation of almost $\$ 7,000,000$ for the Indian service; yet the Florida Indian has not received any part of it, and without it he has shown a prosperous condition. The Smithsonian report, in comparing this interesting people with the native white settlers, says "that success in agriculture and domestic industries is not to be attributed wholly to the favorable character of the climate and soil; for, surrounded by the same conditions, many white men are lazy and improvi- 
dent, while the Seminoles are industrious and frugal."

President Cleveland in his message for 1895 pertinently says, "In these days, when white agriculturists and stock raisers of experience and intelligence find their lot a hard one, we ought not to expect Indians to support themselves on lands usually allotted to them.

Years later, while the late lamented ex-President was fishing in New River at the edge of the Everglades, he said, "This country was made for the Seminoles and they should be permitted to live here undisturbed forever."

Yet in Florida, we find the red race not only selfsustaining, but refusing any aid from our Government. Twenty years ago the Government appropriated $\$ 6,000$, " to enable the Seminoles of Florida to obtain homesteads upon the public lands, and to establish themselves thereon." A few of the Indians consented to accept; but the agent, on investigation, found that the lands which the Indians desired had passed into State or Improvement Companies. Today the Seminole is embittered; and, having been driven from one reservation to another, he refuses to exchange "Indian's good lands for white man's bad lands," and in the bitterness of his conquered spirit, takes his dusky tribe to the dark shadows of the cypress swamps, where no pale-faced Government officer dare disturb him. Again Congress tacked an item to the appropriation act, giving $\$ 7,000$ " for the support of the Seminoles of Florida, for the erection and furnishing of a school for teachers and the fur- 
nishing of seeds and implements for agricultural purposes." In the winter of 1889 , an agent inspired with confidence in himself, and with the hope of manipulating a $\$ 12,000$ appropriation, came to Florida by appointment from Washington to renew the effort " to find suitable lands upon which to settle the Indians, and to furnish the seat of an educational establishment." Securing an interpreter the agent visited the Indian camp. A council of chiefs listened quietly to his overtures, but with the same proud spirit of Osceola's day, they refused firmly to accept any aid from a Government which they regard as having stolen from them the lands of their fathers. As the agent dwelt on the presents the red men of Florida should receive from the big white chief, Tiger Tail, a worthy descendant of the invulnerable Tustenuggee, replied, "You came from Great Chief? You say that Great Chief give Indian plow, wagon, hoe?" Then pointing in the direction of a small settlement of shiftless whites, he added, "He poor man, give 'em him. Indian no want 'em." Delivering his speech with the spirit of an old Norse King, the chief strode majestically away, leaving the agent no nearer the fulfillment of his trust.

An Indian Agency was established, however, in Florida in I892, located east of Fort Myers, and about thirty-five miles from the nearest Seminole camp. It was supported by a yearly appropriation of $\$ 6,000$, the appropriation act reading, "For the support, civilization and instruction of the Seminole Indians in Florida $\$ 6,000$, one-half of which sum 


\section{THE SEMINOLES OF FLORIDA}

may be expended at the discretion of the Secretary of Interior in procuring permanent homes for said Indians."

The Government built a saw mill, and attempted a school, but the Indians, according to the statement of Col. C. C. Duncan, U. S. Indian Inspector at that time, refused to send their children to the school or to work at the saw mill. Many white traders who purchase hides, plumes and furs from the Indians, tell them that the establishment of an agency is for the purpose of rounding them up and sending them west. These Indians have been cheated and baffled so often by knaves, who go among them for that purpose, that they imagine all whites to be of the same character, and cannot tell whether a "talk" comes from their great white father at Washington, or whether some imposter be imposing upon them for his own gains; hence, the Seminole never removed his cloak of suspicion. Little progress was made and the work of the agency as a government institution was abandoned.

Once or twice it has been tried to locate the Seminoles, but when the chiefs examined the land, they found it "ho-lo-wa-gus" (no good) and they refused the offer. 


\section{NATIONAL INDIAN ASSOCIATION}

\section{ITS WORK AND ITS RESULTS}

WHEN the National Indian Association first organized, like many innovations in humanitarian work, it met with rebuffs and criticisms, and not until after five years of petitioning to Congress, newspaper recognition and the circulation of leaflets, did the splendid body receive legal recognition and protection for the United States Indians. With this much accomplished, the work became easier and plans to evangelize the Indians of the United States were instituted.

It became the duty of the Association to gather money for the work, establish stations, one by one, finance the expense of building mission cottages and chapels, and then when established, give the station, with all its property, to whichever of the denominational boards should ask for it.

The work has been one of the noblest of pioneer mission labor, for its activities are directed to America's original owners, whose God-given inheritance should never be questioned by any patriot, whether he be Christian or moralist.

In $189 \mathrm{I}$, this organization entered Florida and the Seminole Indians received recognition and the first ray of Christian light pierced the dark camps of the Everglade Indians.

While the missionary in charge found the work 
difficult and results were not flattering, still, the seeds were sown that have brought later and better results, and in I893 the Mission was transferred to the Episcopal Church of the South Florida Diocese.

During the period of the National Organization's stay in Florida, Congressional agitation of the subject of Seminole lands was aired by deeply interested friends and pauseless workers, and resulted in the voting of 800,000 acres of land by the Florida Legislature as a home for the Seminoles, a gift needing action on the part of Congress to make it a sure and permanent home for this long-neglected people. But this action alas! was never taken. ${ }^{1}$

In giving the Florida Station over to the Episcopal Church, the National Indian Association made no mistake, for through the untiring efforts of the Rt. Rev. William Crane Gray of the South Florida diocese, the mission has each year been getting better results. The Station has been named Im-mo-ka-lee (home), and is situated about thirty-five miles from Fort Myers. Forty miles farther is a hospital, called Glade Cross; here an immense white cross has been erected at the entrance to the glades.

The present arrangement, under the charge of the estimable Rev. Irenæus Trout, seems to be solving

${ }^{1}$ Since the above writing, the Department of the Interior has investigated the status of the swamp land and the Government has guaranteed against purchase 23,000 acres of land to be held in trust for the Indians. Only a small part of it is arable, but when all else is wrested from these Indians, they may retire in safety to this land. 
the mission question better than any former plan. The mission owns a store where the Indians may buy or sell; the missionary in charge may meet and converse personally with the Indians; he wins their friendship and is able by degrees to instill religious thoughts into them. The Rev. Mr. Trout is working along industrial lines, and says, "We must fit these Seminoles by education and Christianity to meet the coming conditions, and teach them to become selfsupporting by industrial pursuits and now is the time to do it."

The work proposed is to erect suitable houses for the residence of the missionary and his family with sufficient room to entertain visiting Indians when in over night and a barrack or rest room for laborers employed in clearing land and working crops.

Of the work and Mission, Dr. Gray says:

To Bishops, Clergy and Laity of The American Church, Greeting:

I desire to commend most heartily my well-beloved in the Lord, Rev. Irenæus Trout, Missionary to the Seminole Indians in Southern Florida. I believe that God has in a marvelous way designated him as the very man to go forward with the work in which he has already been signally blessed, viz: that of leading the Seminoles into the Kingdom of our Lord Jesus Christ. We are now at the very crisis of opportunity.

Hear him and help him. Here is a cry, not from Europe, Asia or Africa, but from the Everglades, in your own Florida: "Come and help us!" A thousand prayers accompany him from this Missionary District. 


\section{THE SEMINOLES OF FLORIDA}

God gives you the privilege of helping this poor Seminole remnant into the kingdom.

Faithfully,

For Christ and the Church,

(Seal)

Wm. Crane Gray, Bishop of Southern Fla.

The Cathedral Church

Of St. Luke,

Orlando, Fla., Jan. 15, I909.

THE FRIENDS OF THE FLORIDA SEMINOLES.

A few years ago great interest was manifested in these Florida wards, when a Society called "The Friends of the Florida Seminoles" was organized at Kissimmee, Fla., with the Rev. William Crane Gray, Bishop of the South Florida Episcopal Church, President; Rev. D. A. Dodge, Vice-president; Mr. James M. Willson, Jr., Secretary, and State Senator C. A. Carson, Treasurer. Other officers (trustees) were the late George W. Wilson, Editor-in-chief of the Florida Times-Union; Hon. J. R. Parrott, President of the Florida East Coast Railroad Co., and Capt. F. M. Hendry, Fort Myers, Fla.

This body, assisted by the active interest and sympathy of Gov. W. D. Bloxam, Mr. P. A. Van Agnew, and Mr. Kirk Munroe, made it possible for the Society to accomplish its State-wide results, numbering among its members philanthropic people from Maine to California.

The object of this society was to enlist the sympathy of the American people for these homeless 
people and to strenuously oppose the removal of the Seminoles from the State against their consent. No really true American, whether he be an Indian sympathizer or not, can feel any but sympathy for the Florida Seminole if he understand the true status of his condition, and when the Society of the Friends of the Florida Seminoles was established, a great wave of sympathy was felt all over the country and requests for membership came in from all ranks, the highest circles of finance, from social leaders, educational centers and government officials. It was recognized an honor to belong to the organization.

The membership list is still open and the Society earnestly appeals to the people of America to take a friendly interest in the future fate of this forlorn remnant, who are one of Florida's most native possessions, and to aid in securing for them permanent homes in the unsettled portions of the State before it is too late.

The interest and work of the Society was greatly aided through the editorial columns of Harper's Weekly, when Edward S. Martin made an appeal in behalf of that band of Seminoles known as the Cow Creeks. The object was to purchase a tract of land on which was located about seventy-five Indians. They had lived here for thirty years, cultivating part of the land and using the rest as a range for their hogs, but as they had no legal title to the land, they were at the mercy of squatters who coveted them. About four hundred dollars were raised, but when the attempt was made to locate these Indians, cow- 
boys and land-grabbers had alarmed them, by telling them that the Government was getting ready to round them up and take them West, and like frightened deer they left their homes and retired again to the swamp fastnesses.

The Society purchased some fields upon which the Indians were camping with Harper's fund - the remainder of the funds being held in trust for its original purpose. The Society secured great public sentiment in their favor, and hoped to obtain lands through legislation. Centuries of wrong from hands too powerful to be resisted have taught these red Americans the patience of despair.

Amid the blessings of Chrisitanity, the Seminole is an outcast from sympathy and an alien to hope, yet he has never ceased to be manly. While we protect the deer and the alligator, the quail and the fish, shall we leave our brother in bronze a prey to the lawless and a helpless victim of every loafer?

The only way to protect these wards of Florida is to buy a reservation, and hold it in trust for them forever.

Even at this writing, that trackless waste of sawgrass and water with its scattering islands and lagoons, constitutes the great political question among Florida people - the drainage of the Everglades.

We cannot but admire the proud and independent spirit of the Seminole as he rufuses, in firm but Indianlike measures, the proffered liberality of a Government which he believes has wronged him. And, from his high pinnacle of pride, he certainly bears the 


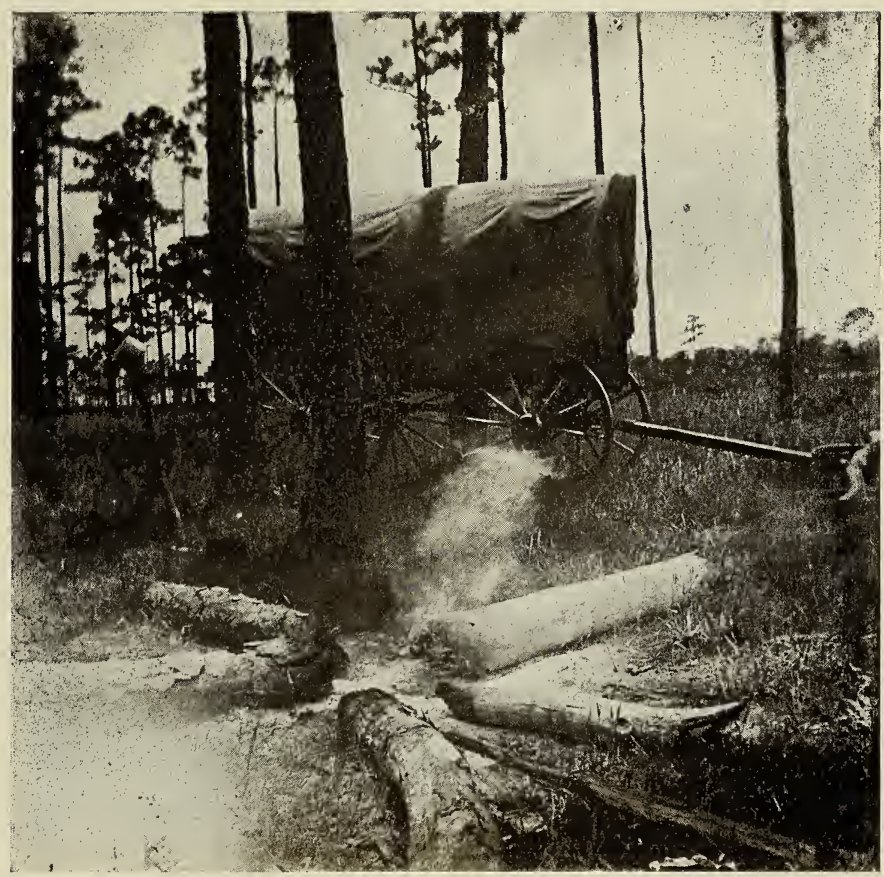

A SEMINOLE CAMP-FIRE

The Indian mode of making a fire. 

distinction of being the only American who has been found unwilling to share the spoils of the nation. So he says, "We have listened to the great father at Washington. The Great Spirit wishes no change in his red children. If you teach our children the knowledge of the white people, they will cease to be Indians. To know how to read and write is very good for white men, but very bad for red men. Long time ago, some of our fathers wrote upon a little piece of paper without the nation knowing anything about it. When the agent called the Indians together he told them the little paper was a treaty which their brethren had made with the great father at Washington, and lo! they found that their brethren by knowing how to write, had sold their lands and the graves of their fathers to the white race. Tell our great father at Washington that we want no schools, neither books, for reading and writing makes very bad Indians. We are satisfied. Let us alone." After this speech delivered in the native tongue, the council breaks up, and the proud Seminole betakes himself to the Everglades. The Seminole is disposed to make a child's bargain with the big white chief : "You let me alone, and I will let you alone."

Photographs of the Carlisle Indian boys have been used to illustrate the improvement which follows education; but the Seminole youth turns away with disdain, as he notes the closely shaven head and the 'American dress, and says, "Indian no want books, make 'em white man, white man mean heap lie too much." With a gesture faithful to the Indian, he 
refers to the "long time ago, Seminoles had lands, cattle, slaves; white man steal 'em." This statement of the Indians is corroborated by the old white settlers of to-day, who fought the Indians. They tell that General Jessup's army, on coming to the great cattle country of South Florida, began a systematic slaughter of all the cattle found. A body of soldiers, too large to fear an attack, would round up a herd of the Indian's cattle and sitting on their horses, shoot them all down. $\mathrm{Up}$ to this time the Indians were regular stock dealers, their customers being the $\mathrm{Cu}$ bans and Minorcans. General Jessup's report of his march into the "Indian country," says, "On the 28 th (January, I837), the army moved forward and occupied a strong position on 'Ta-hop-ka-li-ga' Lake, where several hundred head of cattle were obtained."

The tribe to-day are taught by the chiefs to regard the whites, in general, as lacking in honor and courage, weak and insignificant, or in Seminole dialect, "white man - ho-lo-wa-gus" (no good). This is easily understood when we consider the strong attachment an Indian bears to his native hunting grounds; and when the memory runs back to the time when our Government banished their friends and relatives to the unknown wilds of the West, and they went silent and weeping toward the setting sun. Their bitterness is consistent with their ideas of injustices practiced upon them.

History, romance and poetry have held up the characteristics of the red man to our gaze from childhood. And while treachery may be a distin- 
guishing feature of the Indian nature, yet the lowest one of them has some conception of honor when fairly approached. History shows that all through the Seminole war, misrepresentations and dishonorable schemes were practiced against them by the whites. Almost universal sympathy goes out to this remnant of people who fought so bravely and so persistently for the land of their birth, for their homes, for the burial place of their kindred. As their traditions tell them of the oppression their people suffered as they wandered in the wilderness thrice forty years, who can tell the secret of their hearts? To do this, it would be necessary to become, for the time, an Indian, to put ourselves in his place - and what white man has ever done this? Ask the waters of Tohopeliga, or the winds that waft across Okeechobee. To the elements are whispered the heart throbs of these red fawns of the forest. The present Florida Indians are descendants of that invincible tribe who were never conquered by the force of arms. Refusing in I 842 to accompany their people to the mysterious West, they ceased to exist save for themselves. Finding refuge in the almost inaccessible Everglades, they were for a time almost lost to the historian. They have no legal existence, and hence no rights that a white man is bound, by law, to respect. There are no Indian troubles in Florida at present, but every few months a cry comes from hungry land-grabbers, or from trappers and hunters, that the Seminoles are killing off the deer and plume birds. The changing conditions in the lower peninsular 


\section{4 \\ THE SEMINOLES OF FLORIDA}

country will eventually lead up to difficulties; and "Where shall we locate the Indians?" becomes a serious problem.

The Florida Times-Union editorially says:

All the murderous, cut-throat, unkempt and squalid Indians in the United States whom the Government fears are provided with reservations and such luxuries as they never before had in their lives, but the Seminoles of Florida, the finest specimens of Indian manhood in this country, clean in body, pure in morals, and as brave as the lion that roams the desert, with whom so many treaties have been wantonly broken, are being driven farther and farther into the Everglades and their hunting grounds confiscated to the land grabbers. Is this justice?

Should the whites drive off the Seminoles, and thus approve their greed for land by taking the possessions the Indians now occupy, what good would it do them? Internal improvement companies, by their franchises, would sooner or later take the bloodstained acres from them. Let settlers in Florida, or in any part of the country, turn over their accounts and see how many acres have been credited to them, either from the State or from the general Government, without the equivalent of homesteading or for cash. The "Western" style of disposing of the Indian's inheritance must not be followed in fair Florida. It seems hard that these natives who ask no aid of our nation, should be forced to the wall by the march of civilization. To the Western Indians, under the protection of the Government, and supplied in a large measure by the taxes which civil- 


\section{THE SEMINOLES OF FLORIDA 75}

ization pays, pages are devoted by philanthropists for the betterment of their condition. The rights of the Seminoles of Florida should be defended. The day is not far distant when they must be made to go to the reservation in Arkansas or to lands set apart for them in Florida. To remove them from their tropical homes to the chilling blasts of the Indian Territory would be an act of cruelty and wholly unnecessary. Those of us who have enjoyed life in this land of the palm, this land of the balmy air and life-giving sunshine, reveling in the eternal bloom of the flowers and the ceaseless song of the birds, can well picture the struggle it would cost the patient Seminole to be forced to a cold western land. No, fair Florida, the ancestors of these proud people were forced to the country of the setting sun silent and dejected. But, with the spirit of Osceola, if they must perish, it will be here - here upon the land of their birth, upon the graves of their kindred. The lands they now occupy are of little value to the white race and might be made a safe reserve for them - forever. Cowboys who hunt upon the Okeechobee plains, say the Indians are peaceably disposed and friendly, and have never yet disturbed or threatened. They are certainly not foot-sore for the warpath and are fearful of doing anything to arouse the whites. "Indian no fight," is the answer to the questioner. They have sense enough to know that if war should come again it would mean extermination for them; and their love for the "Flower Land" is so deep that the thought of exile would cost a struggle they dare not attempt. 


\section{THE SEMINOLES OF FLORIDA}

Yet, feeble remnant that they are, with the same heroic blood coursing their veins that inspired their ancestors and made them almost invulnerable, the present Seminole would choose to die rather than submit to removal. And in their swampy fastnesses, they could maintain a contest that would cost us thousands of dollars and many precious lives.

OUR DUTY TO THESE WARDS OF THE NATION.

Under the present status the Seminoles are prosperous, happy and contented. But the vanguard of civilization is marching on, and thinking, friendly minds must solve the question of the protection for this remnant of a tribe we have dispossessed of their natural rights. Dwellers of every land, from Scandinavia to the Congo have a Christian welcome to our shores. The slums of Europe pour in upon us to fill our almshouses and to be supported by our taxes. We have during the past quarter century contributed more than $\$ 50,000,000$ to the education of the freedmen, yet except in individual cases, the improvement is scarcely noticable.

Men and women are sacrificing their lives for the heathen of other lands. Is not the Seminole, this remnant of a long-persecuted people, as worthy of consideration as the oppressed Cuban or the halfnaked Filipino?

Christianity is donating millions of money to this end, while our own "wards," too many of them, are yet living in the dark superstitions of their fathers. 


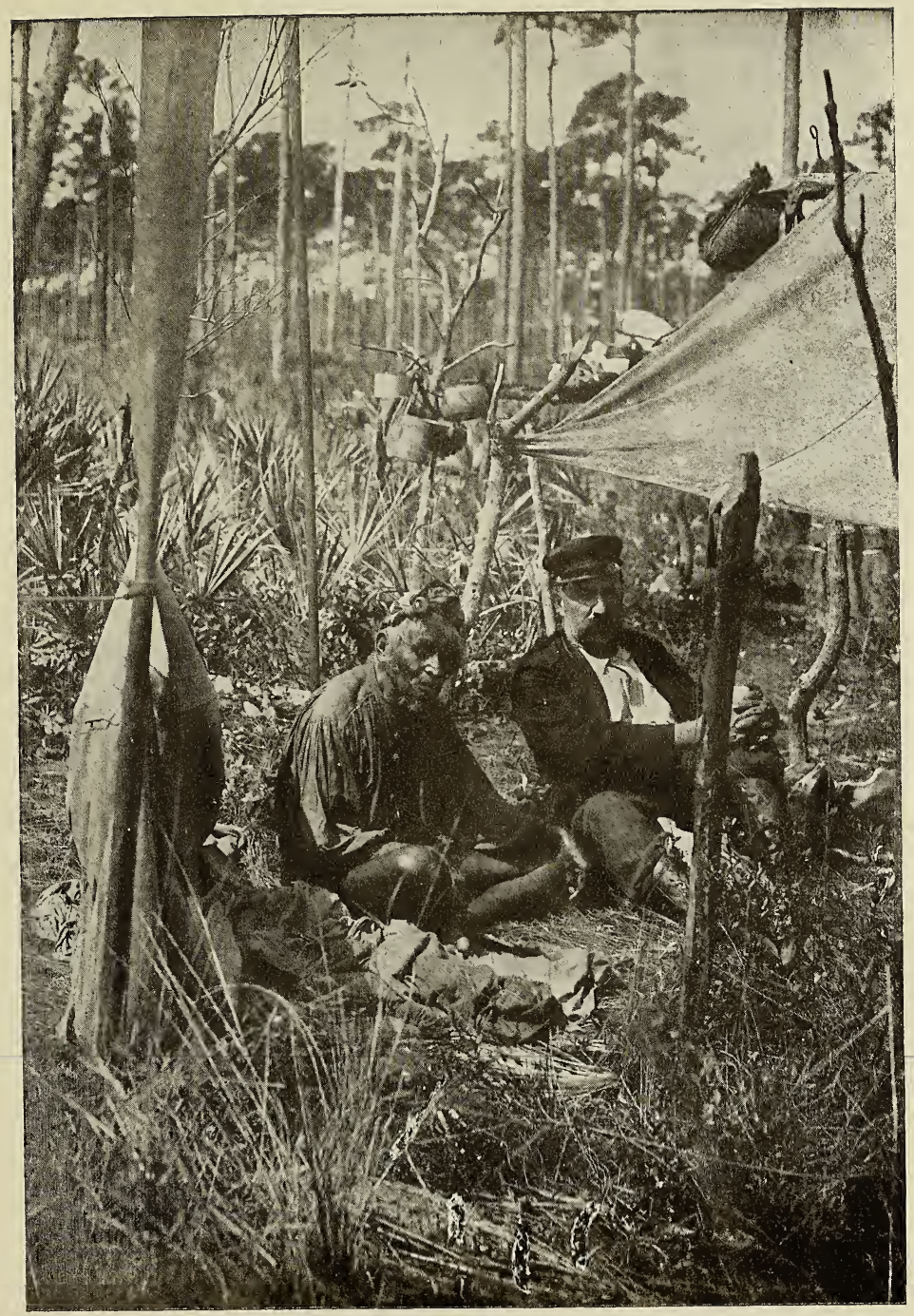

Photograph by E. W. Histed.

CHIEFTAIN TALLAHASSEE, WITH HIS WHITE FRIEND, THE LATE L. A. WILLSON

"The very history of the tribe is carved in poor Tallahassee's face. He is the incarnation of "The Man without a Country." " 

It is possible it will take time and patience before any shining results are apparent. Not until confidence is restored will the embittered Seminole yield to the overtures of our Government. In an educational sense the older Indians will not be benefited, except through the influence of their children. The logic of events demands absorption of this people into our National life, not as Indians, but as American citizens; and the sooner they can be induced to accept lands from the Government, and education for the youth, the sooner will the civilization of the Seminole cease to be a theory. The permanent duty of the hour is to prepare the rising generation for the new order of events that must come. Because these bands of the Seminoles are prouder, more invincible than the old Saxons, because they are savages, yet heroes many of them, all the good of life should not be withheld from them. It has taken years of labor to obtain the shining of even the few rays of light that relieve the gloom of the heathen countries of the Orient. It would be unreasonable to expect the offspring of savages to attain in a short time to anything like the thrift of a Nation like ours. Yet, with a few years of humane treatment, unviolated pledges, with Christian and patriotic examples set before them, this little band of Florida Indians would become worthy representatives of this fair land.

Were any future danger to threaten the United States, the Seminoles would be found to be brave allies. The pledge to General Worth by this 


\section{8}

\section{THE SEMINOLES OF. FLORIDA}

remnant of hostiles, who, in 1842 , refused to emigrate with the rest of their tribe, temporarily agreeing "to confine themselves to certain limits and abstain from all aggressions upon their white neighbors," seems to be held sacred by their descendants. The question was put to Billy Bowlegs, one of the most intelligent of the present Indians, as to what his people would do were the whites to encroach, and take the clearings of his tribe are now occupying, "Would Indian fight?" The young brave replied with downcast face, "Indian no fight, Indian no kill, Indian go." Pursuing the subject further, "but, Billy, by and by, may be one year, five years, may be, white man go, take all your land, take Okeechobee, then where will Indians go?" With the same bowed head, the answer came low and soft, "Me don't know - Indian go." Then to test his idea of an ally, the question was asked, "What would Seminole Indians do, Billy, if the Spaniards from across the big salt water would come to fight the white people of Florida?" Quickly and with spirit came the answer, "Indians help white man to fight." Unless action be taken, there will come a time, when, leaving no trace behind them, the Seminole shall pass out of the world. He shall go, like the mist.

We cannot undo the past, but the future is in the hands of the people. In Canada there are over roo,ooo Indians. They are called the Indian subjects of His Majesty; all held amenable to the law and protected by it. Statistics show that on one side 
of the line the nation has spent millions of money in Indian wars, while on the other, with the same greedy Anglo-Saxon race, not one dollar has been spent, and there has never been a massacre.

The caustic remark that the only good Indian is a dead Indian might apply to the savage Apache; but when one has studied the home life of the Seminoles, observed their domestic felicity, from which many white men might take example, noted their peaceful, contented character, he can only see in them an attractive race, and worthy the proud lineage they claim. Surely if ever the strong were bound to aid the weak, we are bound to help them, to treat them as human beings, possessed of human rights, and deserving the protection of American law. This without doubt, they will be willing to accept, when our nation by kind, courteous and honorable means secures their lost confidence; and when our National Christianity shall take measures to make our land for them a home where they may dwell in peace and safty.

\section{CHIEF TALLAHASSEE.}

Almost four hundred years have passed since that fair April day when Ponce de Leon anchored on the verdant shores of Florida. Since the Spanish cavalier planted the silken flag of Spain upon her soil, Florida has been surrounded by a halo of romance and tragedy. Between the time of her discovery and to-day, what marvelous scenes have been wit- 
nessed upon her fair plains and along the borders of her wild, dark rivers.

The ancient race who greeted the old Castilian has vanished and, save in the little band of Seminoles secreted in the mysterious and weird wilderness of the Everglades, no trace of the red man is visible. A description of a type of this fragment of a people will enable the reader to form a better conception of the tribe as a whole; and no name is more worthy to place in these pages than that of Tallahassee.

The old chieftain in appearance is noble and intellectual, and there is that in his look and bearing which at once pronounces him something more than the mere leader of a savage tribe. While his silvered head marks the cycle of many years, in his attire of scarlet and white, embraced by the traditional brightly beaded sash, he exhibits a dignified and patriarchial bearing. His countenance, while indeed mellowed with the cares of four-score years and ten, is kindly, and shows a conquered spirit. The lineaments of noble features are traceable in the broad forehead, the firm, thin lips, and eyes that might pierce the rays of the sun. Tallahassee shows no resentment to the whites, yet he believes that they have treated the Indian badly.

It may seem strange to talk of gentlemanliness in an untutored savage, but the demeanor of this Seminole chief must dignify any family in the land. But that face! Heaven forbid that any native of free America should wear so sad, almost heartbroken an expression as that which seams poor Tallahassee's 
face. No child could look upon it without being impressed by its mournful pathos. The very history of the tribe is carved there.

When Osceola, with his compatriots, went on the war-path, Tallahassee was a small boy, and remembers well when his father and a few companions were surrounded and killed by the soldiers near Tallahassee, the capital of the State. Chipco, the chief of the tribe, was Tallahassee's uncle; he escaped from the soldiers, and made his way to the Everglades where he lived to be nearly one hundred years old. Rosa, the sister of Tallahassee, became his squaw. They were childless, and at Chipco's death, Tallahassee inherited the title, but as a reward for bravery displayed in saving his life on two occasions, Chipco had made him chief years before he died.

There is no trace of a revengeful spirit in either word or manner when Tallahassee speaks of his father's tragic death, but with the stoicism of a philosopher, he seems to have accepted it as one of the cruel fortunes of war, and has nobly "buried the tomahawk." Tallahassee is no stern warrior with blood-stained hands, but wears worthily the dignities of his ancestral station, and in many ways might be imitated with profit by his more cultured pale-faced brother. He is a true type of the "noble red man," and in any other walk of life would have risen to eminence. Of all the Seminoles, Tallahassee is the most friendly to the whites. With the inborn courtesy that is native to all true greatness, this untutored Indian will welcome you to his wigwam 
and with royal grace dispense the hospitalities at his command. Few enter his presence, and none leave it without this mental tribute to his high character. The old chief is treated with care and consideration, and a homage is paid to him by the younger members of the tribe. Among the Seminoles, when a member of the tribe becomes too old for usefulness or selfhelp, it becomes the duty of the young men to contribute their share to his support. They are taught to do this more as an honor than as a burden.

As the years pass, more pathetic grows the life of the hereditary chieftain.

A few years ago, after numerous invitations, Tallahassee was persuaded to leave his swamp home to make a visit to the home of the writer. The old patriarch was accompanied by Billy Bowlegs, who showed the tenderest care for him. With one horse between them they traveled from the Everglades to Bassinger, the terminus of the steamboat line to Kissimmee. Then they boarded the steamer Roseada, arriving at Kissimmee after two days' river travel. They attracted much attention and were the recipients of many small presents from sympathetic friends. They were both in full costume, the old chief wearing the regalia of his rank, sashes of bead work and red beaded leggins. On reaching the home of their host, they immediately began unpacking the bundle they carried, which indicated they had been preparing for many moons back for this eventful visit. Numerous garments, new and fanciful, were carefully withdrawn. The next morning being the Sabbath, 
they dressed with greatest care for the Sunday School and church services, which they enjoyed to the fullest. Knowing the famous chieftain would attend service, the church was crowded and at the close of the services parents with their children crowded around the old chieftain eager to shake hands with him; and with a pleasant beam of gratitude in his eyes, he received these greetings of the white friends.

It is a pleasing fact that Tallahassee, a savage and the representative of an almost destitute people, received a homage and as kindly a greeting as was ever accorded to any visitor to the little city of Kissimmee. However adverse a man may be to the Florida Indian in general, if he looks into the history of the Seminoles of Florida, he not only becomes friendly, but eager to see justice meted out to them.

As Tallahassee bade "good-bye," he said, "Me no more come to Kissimmee City - old too much." He had come as an ambassador of his tribe to tell his white friends the history of his race, and as memory went back to the olden days of bloodshed and accounts of home after home wrested from his people, he trembled with suppressed emotion. Anguish, interblended with the mournful pathos of his face, made a picture too sad to look upon. It was a period of agonizing struggle for this gallant, but conquered Seminole.

Sad and prophetic were his farewell words, for a short time after he reached his swamp home, he was taken with violent pains in his head, and as Billy Bowlegs reported it, "Pain three days - pain go, 


\section{THE SEMINOLES OF FLORIDA}

- Tallahassee blind ojus" (heap). The old chieftain, though totally blind and physically helpless, rules his band with the same stoic will of days long ago, when he carried them to the wilderness and wrenched them from the white man's bullets and Uncle Sam's bloodhounds. ${ }^{1}$

\section{INCREASING.}

It is generally believed that the Seminoles are dying off, and can last but a few years longer. On the contrary, they have large families of strong, healthy children, and the past ten years has shown a marked increase in their number. The strict law allowing no persons of like gens to marry is a reason why the tribe does not multiply still more rapidly. There are instances where eligible young men find great difficulty in getting wives because of the strictness governing the gens or consanguinity law. One chief has two daughters who find the same trouble in getting married because the men of their choice are too closely connected to them. Thus, a member of the Deer clan may not marry into the same clan, no difference how far removed the relationship may be. Relationship on the father's side is not guarded against so strenuously, as the gens is all counted through the mother. Very often the law of marriage causes strange alliances - young men twenty

1 Since the above writing, word has been received from the Indian camp as follows: "Hungry Land, Fla., Tallahassee, big sleep, one Moon." 
years of age having old women for wives. From the best obtainable resources, there were in the year I 859 , only one hundred and twelve Indians left in Florida. In 1880 , by actual count, as reported by the Smithsonian Institute, the Seminoles of Florida numbered two hundred and eight. According to date gotten from the Indians themselves the tribe to-day numbers nearly six hundred. Of this number a great proportion are young children, or in the language of the chief as he made a numerical calculation of the members of the different families "heap pikcanannies, pikcaninnies ojus" (plenty). The Seminoles are divided into four bands, who live in groups apart; each independent of the other, but. in friendly relation. They are the Miami Indians, the Big Cypress band, the Talla-hassees and the Okeechobees. Since the death of Woxo-mic-co (Great Chief) five years ago, no one has been elected to fill his place, and it is doubtful if his office will ever be filled.

No event in the history of the Seminole tribe since the closing of the war has been more tragic than the slaughter of eight of the band, by the hand of Jim Jumper, a half-breed belonging to the tribe. The killing occurred in February, I89I. According to the Indians, the negro had bought some bad whiskey from a white trader, and it made him "crazy too much in his head"- doubtless delirium tremens. With his Winchester in his hand he started out. The first victim was his faithful squaw who happened to be close by. Rushing forward and through 


\section{THE SEMINOLES OF FLORIDA}

the camp and meeting the venerable Woxo-mic-co, head chief over all the tribe, who was on a visit to the Cow Creek band from his council lodge at Miami, the crazy half-breed sent a ball through the old chief's head, killing him instantly. Old Tom Tiger, one of the landmarks of the Indian wars, hearing the firing, came to the rescue, but was shot down before he had time to interpose. Young Tiger, stepping out of the wigwam in time to see his father fall to the ground, with a blood-curdling war-whoop sprang upon the maniac and a hand-tohand fight ensued; but he was at the wrong end of the rifle, and before he could wrest it from his antagonist, another report was followed by the death-cry of the brave, young Indian. The wildest panic ensued, the women and children huddling in their wigwams or fleeing to the woods. The murderer now rushed into the wigwam of his sister, and with his knife murdered her and her two little children, who were clinging to her dress in terror. Brandishing his knife, he started into the woods, where he was killed by a bullet from Billy Martin's rifle. The wailing and the anguish in that camp can better be imagined than described. After the burial ceremony over the murdered victims, the body of the murderer was dragged far into the swamp, to be fed upon by the vultures. Thus passed away in less than half an hour eight innocent lives, victims to the demoralizing influence of the white man's whiskey. The Indian village was broken up, the 


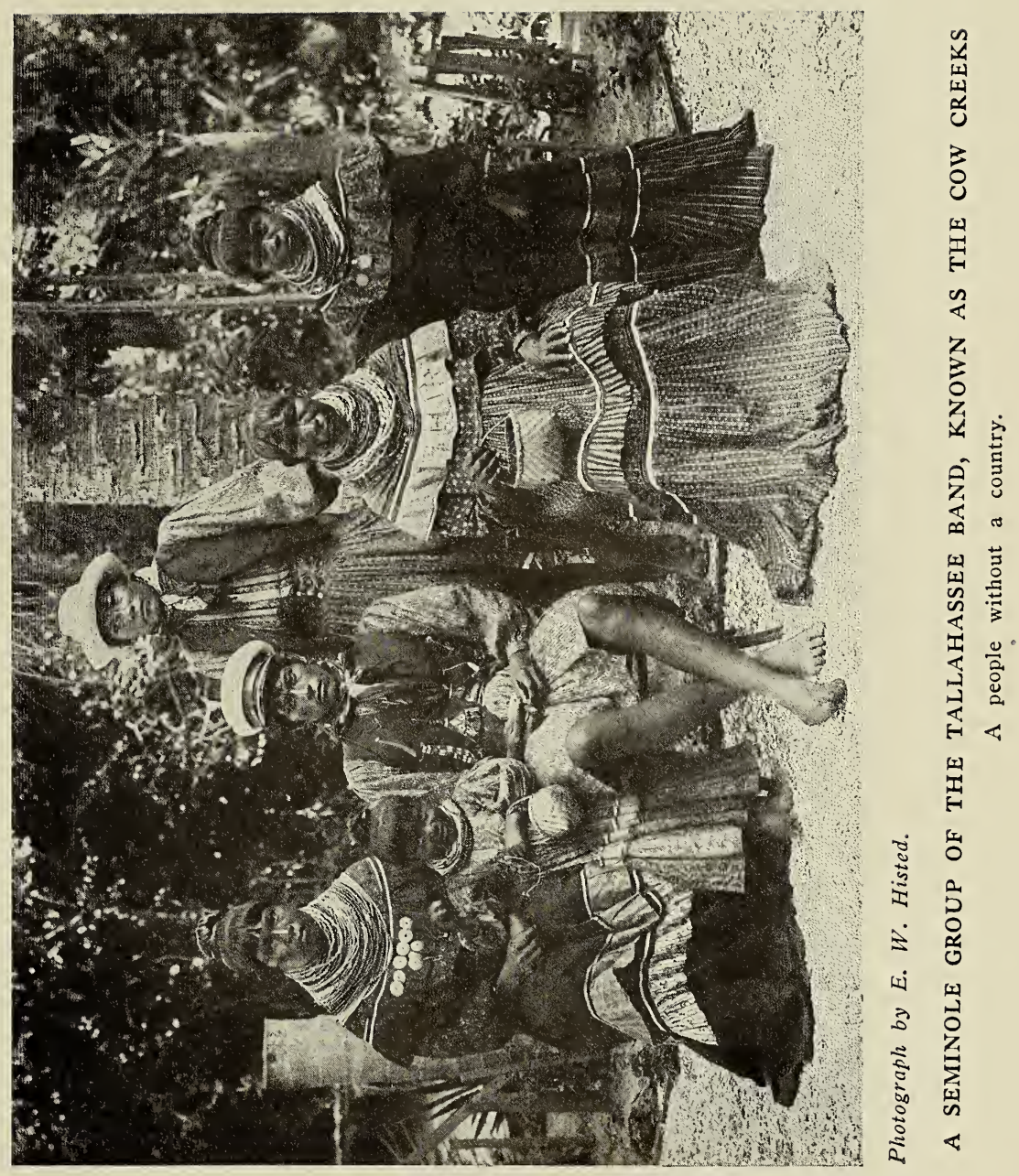



entire band moving away to escape the visitations of the spirits of the murdered ones.

On the death of Woxo-mic-co, four candidates for the position of Big Chief appeared, but five years have passed and yet no chief has been elected. In the old chieftain's death the last vestige of Seminole war spirit is obliterated. Nowhere in their history is their determination to live at peace with their white neighbors more conclusively proven than in the abolition of the office of Great Chief, "Big Chief " and war councils, in their minds, being inseparable.

The authority of the sub-chiefs, who are leaders of the different bands, is purely personal; they cannot decree punishment - a jury or council alone can do this. The government is not harsh, and there is as much freedom as could be possible in these forest homes.

\section{APPEARANCE AND DRESS.}

In personal appearance, many a Seminole brave might be taken as a type of physical excellence. He is bright copper in color, is over six feet in height, his carriage is self-reliant, deliberate and strong. His step has all the lightness and elasticity that nature and practice can combine to produce, as lithe and soft as the tread of a tiger. The Yale, the Harvard or the Oxford student with years of training in the athletic school, would be but a novice in the art of grace, suppleness and mode of walking, 
as compared with this son of the forest. His features are regular, his eyes jet black and vigilant, always on the alert; his nose is straight but slightly broadened, his mouth firm as a stoic's. The hair is cut close to the head, except the traditional scalplock of his fathers, which is plaited and generally concealed under the large turban that adorns his head.

The dress of the Seminole chief consists of a tunic embraced by a bright sash, close fitting leggins of deer-skin, which are embellished with delicately cut thongs of the same material, that hang in graceful lines from the waist to the ankle, where they meet the moccasin. The moccasin is also made of deerskin, and covers a foot shapely and smaller than that of the average white man. A picturesque feature of the dress is the turban. Oriental in its effect, it has become the emblem of the race. It is worn almost constantly; and is made impromptu from shawls or collossal handkerchiefs wrapped round and round the head and then secured in shape by a band, often made of beaten silver which encircles the whole with brilliant effect. With young braves the more important the occasion, the more enormous the turban. Another characteristic of the dress is the number of handkerchiefs worn, knotted loosely about the neck. Regardless of the temperature, the Indian adorns himself with six, eight or perhaps a dozen of bright bandannas, exhibiting great pride in the number he possesses. A belt made of buckskin completes the costume. From this are suspended a hunting knife, 
a revolver, a pouch in which is carried the ammunition and small articles necessary for the chase.

The physique of the women will compare favorably with that of the men. They are healthy and robust, and among the younger members some comely well-featured women are found. The dress of the squaw is very simple, consisting of a straight, full skirt, made long enough to hide the feet. The upper part of the dress is a long sleeve, loose-fitting waist, which fails to meet the waist band of the skirt by about two inches; this oddly fashioned garment is cut large enough in the neck to be put on or taken off over the head. A large collar, fashioned after the collarettes worn by the fashionables of the season of 1896 , completes the toilet. A Seminole woman wears no head-dress of any description. Even when visiting the white settlements they go with their heads uncovered. Neither do they wear moccasins, at home or abroad, in winter or in summer. They are always bare-footed.

Vanity and coquetry are inborn in the female character. The Seminole maiden whose life has been spent among the swamps "far from the madding crowd" and fashion's emporium, still practices the arts of her pale faced sister. She affects the bang and the psyche knot with as much ease as the New York belle, and with such metropolitan airs soon captivates her forest lover. The same passionate desire for gold and jewels, ever uppermost in the heart of the civilized white woman, be she peasant or queen, shows itself in the Seminole 
squaw. Silver breast-plates, made from quarters and half dollars, beaten into various designs, add to their personal adornment on festal occasions. What the turban is to the brave, such is the necklace of of beads to the woman. It is her chief glory and is worn constantly. Her ambition seems to be to gather as many strings of these highly colored beads about the neck as she can carry, often burdening herself with several pounds. Even the wee tots are adorned with small strings of the much prized necklace.

Many years ago, when the Indians were encamped on the Kissimmee River, Chief Tallahassee with two or three of the squaws visited Kissimmee. Being taken into a room to see a newly-born babe, he directed a squaw to take from her neck a string of beads and put it around the neck of the "little white pappoose." This was done as an act of greatest honor, to show the Indian's appreciation of hospitalities received at this house.

\section{INDEPENDENCE AND HONOR.}

To-day as we meet the Seminole "at home," we find the wigwam made of palmetto leaves and the skins of wild animals; the floor of this structure is made of split logs and elevated about two feet above the ground. A few of the Indians have in late years built board houses, but the roof is made of palmetto thatch. Here, surrounded by the gloom and weirdness of the Everglades, miles from white 


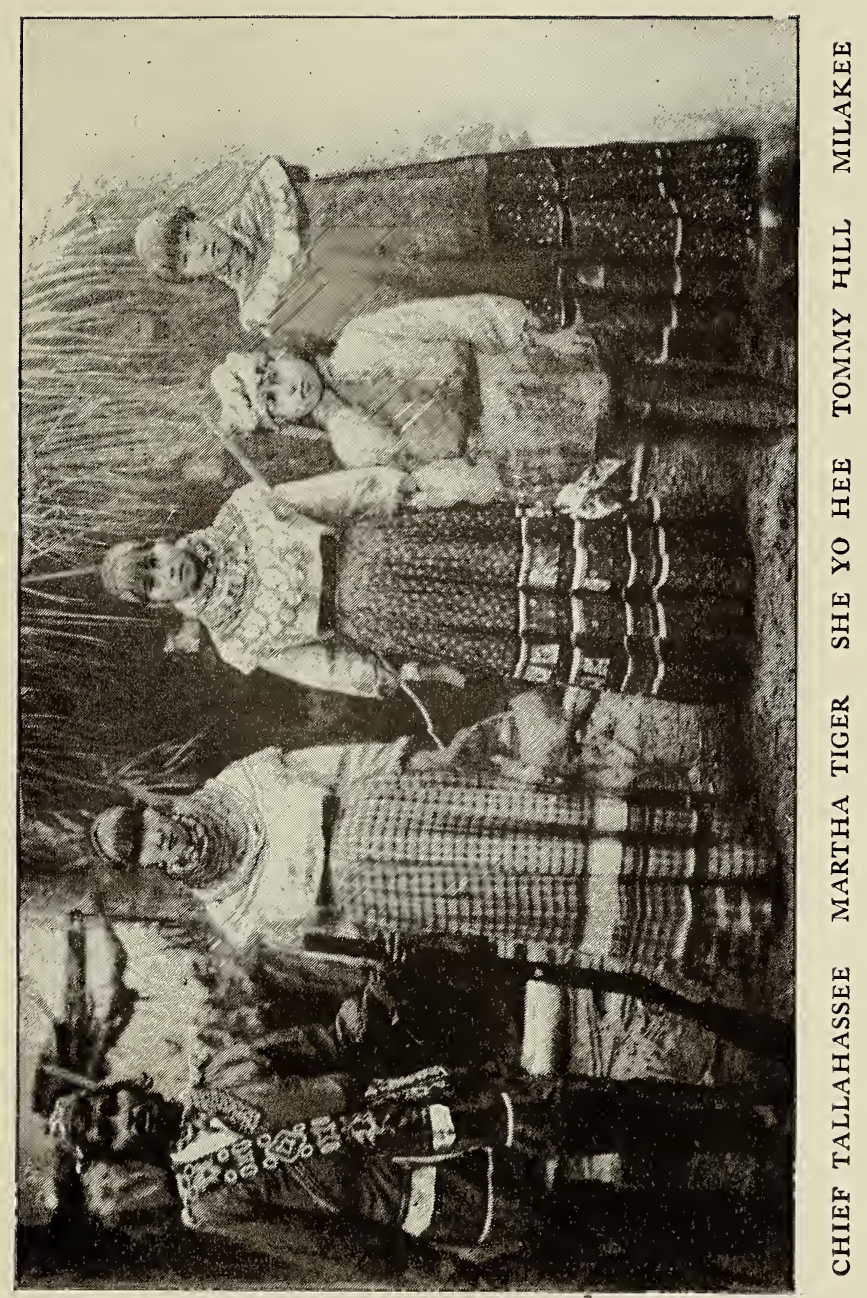



man's habitation, the baying of the alligator, the hooting of the great horn owl, and the croaking of the heron are the only sounds to be heard. Truly the picture is one of melancholy and profound dreariness. But here we find the aborigines contented because they are out of the white man's power. Here they hold their councils, here around the camp fires the traditions of the old turbaned tribe are taught to the youths; here, too, they follow the same customs of the race of one hundred and fifty years ago. Here is instilled into the youth the story - of the perfidies practiced upon their fathers by the white man; and as the children listen to the glories of Osceola, and the tragic ending of their hero, the spirit of conservatism is engendered, and with swelling hearts they go on, on, resolute in their determination to avoid disaster, by keeping aloof from the white man. Although far from the influence of civilization, knowledge has come to these people naturally which we have painfully acquired by books. Driven to these Florida jungles after a seven years' bloody war, here the Seminole, thrown absolutely upon his own resources, has continued to dwell. He has accepted no aid, his people have increased, and in a manner have prospered. No alms-houses are supported for their benefit. This independent Indian does not increase the expense of the jail nor the penitentiary; he is no starving Indian who must be fed at the expense of the Government. In these red sons of the forest we meet the original "real Indian," unchanged by contact with the white man. 


\section{THE SEMINOLES OF FLORIDA}

The visitor to the "Wild West," who complains that "the Indians do not look like the Indians of fifty years ago," would have little ground for his complaint were he to visit the Seminoles in their marshy fastnesses. Florida can boast of one of the few tribes of "real Indians" in the United States. The present Seminole must be credited with a high sense of honor; and he can keep a pledge as well as did Massasoit. A few years ago, during a teriffic coast storm some Indian braves asked shelter of a Florida settler. The Indians were received and entertained until the weather settled. On leaving, the chief sweeping his hand toward the broad Savannah, said, "Captain, hunt deer?" The answer was "Sometimes." "Indian no hunt Captain's deer," was the rejoinder. Very little in itself, but it meant much, for since that time there has not been an Indian hunter within miles of the place.

Famed in song and story is the pledge of the old turbaned tribe of the Seminoles. Not more worthy are they of commemoration than their descendants of to-day. A few months ago, Billy Bowlegs and Tommy Doctor paid an unexpected visit to Kissimmee. They walked from their camp at Okeechobee Marsh, a distance of one hundred and twenty-five miles to tell their white friend that "Indians no lie." This was all. They apparently had no other business in town, and after a few hours' visit left as quietly as they had come. Their mission was completed, their white brother believed them, their honor was clear; 
they could now dance at the Green Corn Dance with merry hearts.

A few months prior to this, these Indians had promised their white friend to act as guide on a bear hunt in the Everglades. All arrangements had been made for the hunt, except to fix the time and place of meeting. This was to be done through a white settler. Later, plans for the hunt were perfected, and word was sent to the Indian village. According to their promise the Indians came to the settler's home on the day specified, but found that the white man had left his house early in the morning with no message as to how or where the Indians should follow. The Indians, not knowing which way to go to find the party, could do nothing but return to their camp - a distance of forty or fifty miles. Subsequent developments proved that the white man wished to act as guide, and thereby earn for himself the remuneration he expected the Indians would receive.

THE SEMINOLE'S UNWRITTEN VERDICT OF THE WHITE RACE.

"Es-ta-had-kee, ho-lo-wa-gus, lox-ee-o-jus"

(White man no good, lie too much.)

In some mysterious way, the Seminole's conception of the Decalogue neither to lie, nor steal, nor cheat, is the foundation stone upon which he builds his character, principle and honor, for it is taught to 


\section{THE SEMINOLES OF FLORIDA}

the race, from the cradle to the grave, to the swinging papoose on its mother's shoulders, all through life, till the Great Spirit calls to the Happy Hunting Grounds. Let the reader stop and consider that here is a community of hundreds, living in open palmetto camps. No locks, no doors, no courts, and no officers to keep the law; a people, who for generations have lived, pure in morals, with no thieving, no trespassing, and no profanity (for the Seminole has no oath in his language). With his conception of the Deity, he reverences the name of the Great Spirit, and "Thou shalt not take the name of the Lord thy God in vain," he venerates, as did the Hebrews in the days of Moses. What would be the result if an equal number of the negro race were left under the same conditions for two generation? Nay, what would be the history of six hundred whites forced to live for even twenty-five years like the Seminoles?

With the Seminole's power to condense into a single phrase, he crystalizes his verdict of the white man into the above forcible expression. In pathetic, but terse language, it tells of generations of wrong treatment at the hands of the white brother; sharp practices and broken treaties, and misrepresentations are all included in the general summing up.

From his oral lexicon, he has chosen these few words, which reveal the throbbing inner soul of these red children of the forests.

No pages, no volumes, no libraries are required to chronicle his experience. 


\section{THE SEMINOLES OF FLORIDA 95}

$\mathrm{Be}$ it remembered that all history of the relation of the two races has been written by the white historian, but were the Indian to write the story, the other side of the picture would be shown. The complaints of the white man are carried, as it were, on the wings of the wind, while that of the poor Indian is drowned in the tempest.

With a stoicism born of generations of training, the Seminole shows no ill-will, no resentment, and the harshest criticism he ever makes against his white conquerors and victorious brothers is this phrase, "Es-ta-had kee, ho-lo-wag-us, etc." And whether in vindication of some offense, or given as a simple opinion, his pent-up feelings find expression in this one forcible epithet, and seems to be the missile he hurls at the white man.

The average American with his standard of morals calloused by dealings in the business and social world, smiles at the Seminole's verdict of his character and with indifferent shrug, jocularly repeats it as being only - the opinion of an Indian.

But, measured by the Indian's conception of honor, how small we must appear to the Seminole patriot, for, from his unwritten code of ethics, to one who knows the well grounded Indian character, his estimate of white manhood means more than is apparent underneath his calm exterior.

\section{ENDURANCE AND FEASTS.}

When one sees the great moral strength of the Seminoles, notes the wonderful physical endurance 


\section{THE SEMINOLES OF FLORIDA}

of which they are capable, observes the fearless, haughty courage they display, he cannot but be surprised that the Florida wars were not more disastrous than they were, or that any of the Seminoles ever yielded to removal. To test their endurance the old chiefs have been known to take a live coal from the camp fire, place it on the wrist and without an emotion let it burn until the heat was exhausted. Tustenuggee would remove the cool ember and quietly reach down and put a fresh one in its place. This old chief, so famous in history, never yielded to removal, and lived till a few years ago with his tribe in the Everglades. The goal of the Seminole is to learn to endure and to achieve. To this end is every Seminole boy educated, and different modes of developing the powers of endurance are employed. Carrying a deer for a long distance without fatigue, walking or running for many miles, jumping, wrestling, poling a canoe, etc., are some of the practical modes. The Spartan spirit is supreme in the minds of the tribe, and the youth are taught that no merit is greater than that of bearing pain without complaint. At the annual feast of the Green Corn Dance the young Indians of a certain age are initiated into the rights of warriors, and are subjected to trying ordeals. They must pass through the "Insha-pit," which means the cutting of the legs till the blood flows, and other cruel arts, after which the Indian boy is pronounced a warrior, ready for the battle of life, whatever the Great Spirit decrees. It is the strict adherence to the teachings of their ancestors 
that makes the present generation the brave and proud people that they are.

Strange as it may seem, the Seminoles celebrate a Christmas - "All same white man's Kismas," is their reply when questioned concerning the celebration. This is the great feast day of the Shot-caytaw," (Green Corn Dance) and occurs each year about the first of July, and is the time for assembling the whole band.

The ceremony is largely under the control of the Medicine Men, who are important personages among all bands, and act as advisers, as priests and as doctors. In the authority of the Medicine Man one recognizes a similarity to the priests of the Ancient East as well as the doctrines laid down by the Aztecs. The festivals observed by the Florida Indians show teachings centuries old - blending the peculiarities of different races - the carnival of the Romans, with the Jewish feasts of Moses's day, and the mystic link of the Aztec jubilee.

The Feast of the Shot-cay-taw has many similarities to the historical records of the National Festival of the Aztecs. The feast is for sorrowing, rejoicing and purifying. This is the beginning of the $\mathrm{New}$ Year when, following the traditions of ancient people, old fires are allowed to go out, not a spark is allowed to remain. New fire is produced artificially; this is the Sacred Fire and must be made with the flint rock of their ancestors. The new fire is presented from one tribe to another, and is received as a token of friendship. Then they as. 


\section{THE SEMINOLES OF FLORIDA}

semble around the fires singing and dancing. Gratitude is expressed to the Great Spirit, if the year has been abundant. If death has overtaken the tribe mournful strains expressive of pity and supplication are invoked. This custom was borrowed from the ancient tribes who worshipped the sun. The Medicine Men arrange the date for the Green Corn Dance, which is governed by a certain phase of the moon, and runners are sent from band to band to announce the time.

The ceremony preceding the dance permits all men who have evaded the laws to be reinstated by indulging in certain trying ordeals. The transgressors appear a short time before the dance. They are placed in a closed skin tent where a large hot stone lies on the fire. The famous "Black Drink" of Osceola's time is administered, water is poured on the stone, and the culprits are shut up in this suffocating heat. If they pass the ordeal, they are forgiven and allowed to join in the feasting and dancing when it occurs. This same "Black Drink" which is a nauseating medicine from herbs, is taken by all the tribe on the first day of the dance. This cleanses the system and enables them to "eat, drink; and be merry" to the fullest extent.

At this great re-union, old friendships are revived, courtships take a prominent part, and plans are formulated for hunting expeditions, syrup boilings and "Koonti" gatherings. Members of one settlement will agree to meet certain members of another family at a certain point on a fixed day of the moon. 


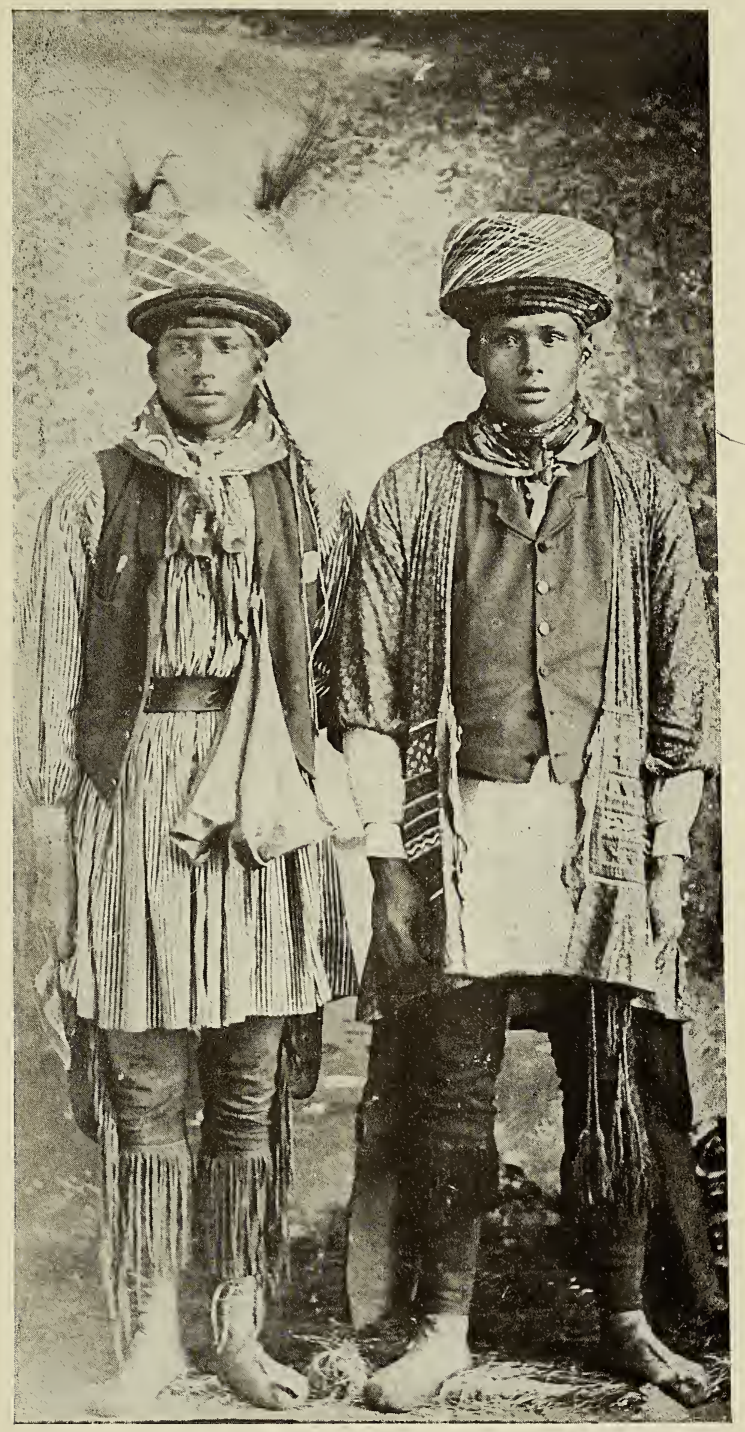

BILLY BOWLEGS AND TOMMY DOCTOR

"They walked one hundred and twenty-five miles to tell their white friend, 'Indian no lie.," 

There will be no broken pledges - no disappointments. The Seminole promises nothing to his people that he will not fulfill.

One of the most picturesque games enjoyed by the Indians during this festival is the dancing around the festal pole. On the night of the full moon, they dance from sunset until sunrise. It is very interesting to see the harmony in running around the circle. As the women throw the ball at the pole in the center, the men catch it in their bags that are made around bent sticks, which have bows each about four inches in diameter, with a cross at the lower side.

When the dancing is over, the circle about the pole is perfectly symmetrical, and about ten inches deep, made by the running and dancing.

An exciting feature of the dance is the racing for a wife. A level course is laid off and the race begins. The dusky lover selects the maiden for whom he would strive, because he must catch her before he may court her. The Indian girl is his equal, and often his superior in fleetness, and need not be caught unless she so wishes. But, like her civilized sister, she generally encourages the pursuit until she is tired, and then gracefully yields on the homeward stretch. However, should she win the race the young lover need have no further aspirations in that direction. He may be saved the embarrassment of future humiliation. 


\section{IOO THE SEMINOLES OF FLORIDA}

\section{THE HUNTING DANCE.}

But the Hunting Dance! What memories of centuries past are kept alive by this brown-skinned race, as they observe the ancient feast of an aboriginal people.

With an invitation from the old chieftain, Tallahassee, who is patriarch of the tribe, to attend the Hunting Dance or Harvest Feast, the temptation was too great to resist. This festival occurs only in cycles - once every four years - and the character of its observance is known to but few, if any, white people. The Indian camps are so inaccessible that it takes nerve and muscle to reach them; but knowing that the entire band of Indians would be on hand in gala spirits and gorgeous attire, and knowing, too, that it was an opportunity that might come but once in a lifetime, the question of "to go or not to go," was soon settled, and preparations for the irksome journey were under way.

By train ride of one hundred and sixty miles we reached a little Florida hamlet, where a teamster with a creaking wagon and a pair of lean, cadaverous-looking horses were secured. Then followed a drive of thirty miles through ponds, swamps, prairie flats, slush and water; with sand-flies whirring and buzzing in our ears as they seemed to offer their orchestral escort through the dismal funeral Allapata flats. The journey was nearing its end. The sun, shining with a July fierceness, glinted the wigwams of the Seminoles. Tired and hungry we ap- 


\section{THE SEMINOLES OF. FLORIDA IOI}

proached the village. Here the signs of the festival were everywhere apparent. With the inborn courtesy, that is ever present with these untutored Seminoles in the presence of a friend, they met us with royal grace. A wigwam was placed at our disposal, out baggage was unloaded, and in a quiet and unobtrusive manner a fine saddle of venison was presented.

The Indians were bubbling over with excitement, for it was a time of rejoicing - a carnival, when men, women and children all joined in the merriment.

'As our visit always means presents for the Indians, expectant faces from the little toddling children, as well as from the older members of the camp, reminded us that it was time to distribute tobacco, pipes, red handkerchiefs, trinkets for the women, candy and nuts for the little ones.

Happiness pervaded the Everglade village. The older Indians, with the exception of the old chief, played like children, keeping the joyous revelry up from hour to hour.

The afternoon of our arrival was devoted to a ball game. An aboriginal ball game! Certainly played by a code of rules more than one hundred and fifty years old, where no curved balls nor Yale coaching had entered, but where swelled and echoed the glad free trump of joy as the game went on with scientific strokes and measured tread, with now and then a "rush" as the ball missed its target and bounded out of its circle. Both men and women participated in the game, the women being as adept 


\section{IO2 THE SEMINOLES OF FLORIDA}

as the men. The game is unique, and might be practised with much pleasure by our American boys.

Within a circle whose circumference is about thirty feet is erected a pole, which serves as a goal. The players take sides, or in country school parlance, "choose up." The object of the game is to strike the pole with the ball, which is knocked with a racket or stick, which is made of hickory, with a netted pocket made of deer thongs.

The ball is tossed up and caught in the netted pocket, and then hurled at the pole. The opposing side endeavor to prevent the ball from touching the post. Sometimes the ball strikes the ground away beyond the line of play, and then a scamper for it is a moment of great excitement. Men, women and children make a rush for the ball, the victor having the next play. A scorekeeper stands by the pole, keeping a record of the play.

As the twilight falls the players end the game and the feast begins. The edibles are distributed into three parts, the men taking their portion and going to a selected spot, the women likewise to a point designated for them, and the children to a third location. This peculiar arrangement is not indulged in at any other time, but has some ancient significance and is followed at this festival.

When the feast is over, which consisted of the fruits of the chase and the best products of the little palmetto-fenced gardens, the band assembled for the grand hunting dance. Campfires burned all around the dancing square, and as the dusky forms emerged 


\section{THE SEMINOLES OF FLORIDA IO3}

from the shadows of the great live oaks, clad as they were in most fantastic attire, the scene was most picturesque.

Women, men and children gathered at the council lodge. Yards and yards of brightly-colored ribbons floated from the head, neck and shoulders of the women, with beads of various hues and many pounds in quantity around their necks, while beaten silver ornaments fastened on their waists added to the decoration. The men, likewise, were in brilliant coats and enormous turbans, with leggins gracefully adorned with the fringe of the doe skin, with moccasins fresh and new. Nor had the children been neglected, for, with swirling ribbons and bright red dresses that reached to their slim ankles, they came bubbling with joy and laughter, ready to take their places in the dance circle.

Now the dancers are ready. In the centre of the square the fire, the Sacred Fire, flashes and flickers. At each corner of the square stands a pole. The leader, who on this occasion is Chief Bill Stewart, waits at the door of the lodge. He starts a weird melody, and the band locks hands, marking time as they make up the chant. The chief leads off the entire band in the procession, making as picturesque a figure as was ever witnessed in a New York cotillion.

With the reader's permission to digress - pertinent at this point is the ironical comment of an editorial writer in one of the great dailies, when he says, "Fancy Lo in a stove pipe hat." We have 


\section{THE SEMINOLES OF FLORIDA}

seen him and he makes a good-looking native American. As he approached, the splendid form of Billy Doctor was recognized in stove pipe hat, full evening broadcloth suit, with white cravat, low cut waistcoat, and satin lined "spike tail" coat. The entire outfit was possibly the gift of some Palm Beach tourist. To Billy's credit, he only wore the costume for fantastic effect.

If the reader will follow the lines of the accompanying diagram, tracing from left, he will see that the long line of dancers, as they pass around the poles, appears to be coming and going, sometimes three and four abreast, but all in such symmetrical motion that the dance is very beautiful, coupled with

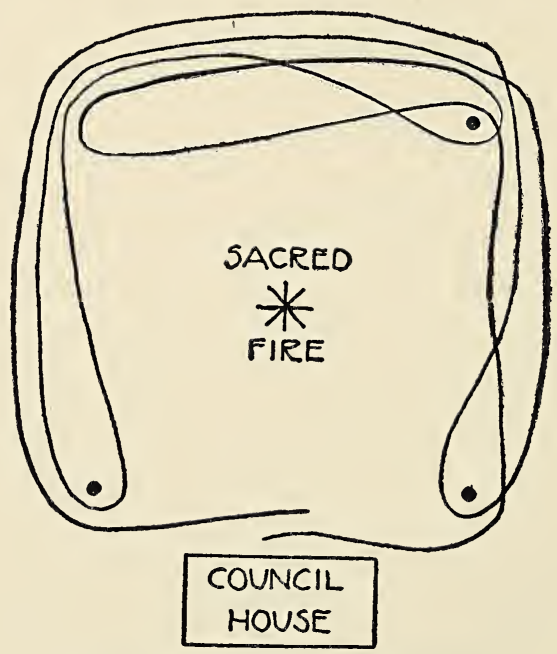

THE HUNTING DANCE. 


\section{THE SEMINOLES OF FLORIDA 105}

the grace and modesty of innocence, with an accompaniment of singing strangely sweet.

The various dances of these people show how close they live to nature. As they move to the rhythmical cadence of the owl song, we hear "Waugh-ho-ooowhoo whoo," of the great horned owl; then the penewa, or wild turkey dance, with its notes of the gobbling bird; and so on with many others.

A feature of the dance, and one that might be commended, is that those who dance must work or hunt. Each morning of the festival every member of the camp, down to the wee child, must hunt, leaving the camp by daybreak and hunting till twelve o'clock noon. The men hunt large game; the boys go for rabbits, birds and squirrels; while the women hunt the hogs and dig potatoes, and the very small children "hunt" water, and bring in sticks of wood. To their white friends, they said, "Dance to-night?" This was intended for an invitation, and was an honor rarely accorded; but with the stern, unwritten law before them, they explained, "White friends must hunt, hunt, hunt. All same Indian. No hunt, no dance."

Another picturesque game is the dancing around the festal pole. In this dance, the women enter from one side, and the men from another. Around the ankles of the women are strapped clusters of shells of the highland terrapin, partly filled with pebbles; these shells are concealed by the long dress skirt, and as they dance, singing the long-cadenced song of their fathers, they make melodious music. A remarkable 


\section{I06 THE SEMINOLES OF FLORIDA}

feature in the perfection of the dance is that as the women move off not a sound is heard, that bunch of shells is as silent as the tomb; and yet it would be practically impossible for one to move the shells by hand without causing them to rattle.

There is so much that is elevating and purifying in the conduct of these people that it would be hard to describe the scenes, the love and good humor that flash between the moments of the times spent in the council at the feasts and the dances.

\section{SLAVERY.}

That slavery existed among the present Seminoles has been a disputed question. That it did is known to a few; but any interference would have been received as an act of impertinence by the Indians, as well as by the slaves themselves; as was evidenced a few years ago when a tourist meeting Tustenuggee's slave (who was watching his master's canoe while his master sold some skins) attempted to enlighten the negro on his true condition. As the chief came back to the canoe, the philanthropist stranger began to explain his mission. The chief, with the ferocity which at once stamped him as a true Tustenuggee, ordered the negro to "go,", which command was instantly obeyed. Then, turning to the stranger, he said, "White man's slave free. Injun este lusta (negro) belong to Injun - now you go." The philanthropist also quickly obeyed.

Tallahassee's squaw died about thirty-six years ago, 


\section{THE SEMINOLES OF FLORIDA IO7}

leaving a family of six boys, the youngest one being but a small pickaninny. These boys were cared for by the two negro slaves who spoke only the Seminole language and were perfectly content to do the drudgery for the family. The number of slaves among the remnant left in Florida was small, but they were allied to the Indians and, while treated kindly, they were expected to obey. In the last few years they have all died off with the exception of one old slave, Hannah, in the Tallahassee band.

HANNAH, THE LAST LIVING SLAVE OF THE SEMINOLE INDIANS.

A character holding a position unparalleled in Uncle Sam's domain, is Hannah, the negro slave, belonging to Tallahassee's family. She is a fullblooded negress, with thick lips, broad flat nose and kinky hair, which is tied in little plaits with the proverbial string of the Southern negro.

Hannah is the last vestige of Seminole slavery the one great subject of warfare seventy-five years ago between the Seminoles and the Southern planters, and upon which, truly speaking, was based the "Seven Years' War." Hannah does the work of the family, and, though she is kindly treated, yet a certain contempt is felt for her, for Hannah is an este lusta (a negro) and to the haughty Seminole a negro is the lowest of human creatures.

The occasion when Hannah's picture was kodaked is fresh in memory. All preparations were being 


\section{I08 THE SEMINOLES OF FLORIDA}

made for the feast, but Billy Ham, Tallahassee's son, had not been able to get a deer, and so had purchased beef from a market thirty miles away. With pots and kettles in evidence, Hannah was preparing the beef, when the little box-like instrument was gently rested on a rail near by. Hannah's eye detected the object and she turned away, and began busying herself around the boiling kettle on the ground. The camera was adjusted, finger on button ready to snap, and a masked indifference affected, and an animated conversation begun with one of the Indians near by. When Hannah returned to her work about the table, snap! went the button, and Hannah's ebony face and twisted, string-tied locks was photographed on the plate, and proud was the owner to possess so good a likeness of Uncle Sam's one and only unfreed slave.

\section{UNWRITTEN LAWS.}

The government among the Seminoles is peculiar, it is remarkable, it is magnificent. There is no lying, no stealing, no murder and yet apparently there is no restraining law. The Seminole has many noble traits; he is proverbially truthful. Pertinent was the reply to the hunter when he asked if it was safe to leave his gun in the wigwam. "Yes," replied the chief, "there is not a white man within fifty miles of the place."

Reverence, too, is one of his distinguishing features. His language contains no oath, nor any word 


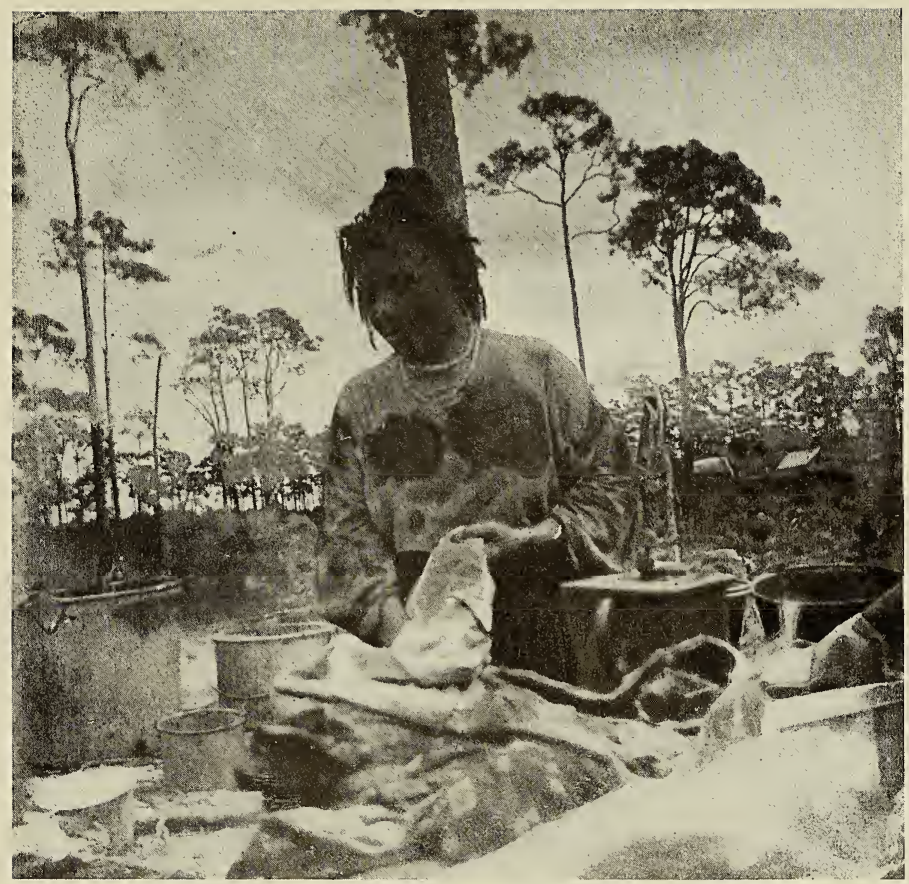

HANNAI, THE ONLY REMAINING SLAVE OF THE SEMINOLES

In Tallahassee's camp making sofka for dinner. 



\section{THE SEMINOLES OF FLORIDA IO9}

to express disrespect to the Supreme Being. A missionary will receive most respectful attention, for their reverence to God will not permit them to laugh at His messenger.

If the annals of this heroic band were chronicled, they would say, "They are prouder than the proudest Inca, braver than the boldest Saxon knight, fearless and unrelenting as foes, devoted and unflinching in friendship, and the purity of their morals without a parallel in the history of any other race or tribe on the globe."

Anxiously and carefully have we studied their form of Government, knowing that they leave their money, their trinkets and their garments in the open wigwam. With carefully-framed questions we asked of Billy Bowlegs, while on his recent visit to our home, "Billy, your money, you leave it in your wigwam, you go back, money hi-e-pus (gone), Indians steal it, then what you do?" $\mathrm{He}$ answered, "Me don't know." "Yes, but, Billy, white man come in my house, my money steal 'em - by-and-by, in jail me put him. Indian, all the same, bad Indian steal. What does Indian do?" Again the answer came, "Me don't know." Making the points plainer, illustrating by the theft of his gun, his provisions, showing him that a bad Indian from one of the other settlements might come in his absence and steal his Winchester, with perfect understanding of our meaning, the reply came as before, "Me don't know, Indian no take 'em - Indian no steal." In such a socialistic State, where there is no crime, there 


\section{IO THE SEMINOLES OF FLORIDA}

can be no punishment. Were a crime to be committed, a council of chiefs would meet and decree a punishment, and it would have enough severity to serve as a lesson for all future miscreants.

The only "fall from grace" we have ever known among any of the bands, extending over a period of twenty years' acquaintance, was in the case of Buster Flint. Old Buster was a large, powerful Indian, but as the braves express it, he was "ho-lo-wa-gus" (no good), "lazy too much," and laid around the settlement as a regular loafer, too indolent to work or hunt; and in consequence was ragged and unkempt. On one occasion, while our tent was pitched near the palmetto wigwams and the hunters had been absent for the day, on the return a small red napkin was found to be missing. Upon calling Captain Tom Tiger's attention to the fact, he replied, "Me know," and very soon the napkin was quietly returned to its place. Old Buster could not resist the bright red cloth and the others knew his weakness. What punishment was meted out to the old Indian was not learned, but certainly enough to terrify him during the remainder of our visit.

The Seminoles mean to be honest in their dealings with the whites. Occasionally the white man may be deceived when the Indian intends no wrong. As the National Editorial Excursion once made a tour of Florida, the train made a stop at a little trading post on the east coast. Quite a joke was innocently played upon the party by Captain Tom Tiger. A few Indians had come into the village 


\section{THE SEMINOLES OF FLORIDA III}

to trade at the stores. Captain Tom had brought with him a load of sour oranges which grow wild in the region of his camp. The oranges are beautiful to the eye, but oh, how bitter! The merry. editors saw the golden fruit and immediately offered to purchase. The chief was glad to sell, and only asked one cent apiece for the fruit; but the editors would not take advantage of the Indian's ignorance of the price of oranges, so they paid him twenty-five cents per dozen for them. At this the load of oranges was soon disposed of and the chief, with perfect honesty of intention in the transaction, was the proud possessor of about twenty-five dollars. Those of the party who first tasted the fruit said nothing until all the oranges had been bought; then they were told to taste their oranges, and a laugh, long and loud, went up from one end of the car to the other, and as the train rolled away the goodnatured but victimized passengers treated Captain Tom Tiger, chief of the Seminoles, to a shower of sour oranges. The Indian was dumbfounded. The wild orange is an article of barter in Florida, but not until the idea dawned upon Tom that the excursionists had mistaken his fruit for the sweet orange did he awaken from his bewilderment, and with earnest nods of the head and impressive gestures he soliloquized, "White man no like Indian's orange - sour too much. Me tell white man, one orange, one cent. White man tell me one orange, two cents. Indian no cheat white man."

The Seminoles look upon the dim past as a lost 


\section{2 THE SEMINOLES OF FLORIDA'}

paradise in which there was happiness and innocence. "Before the white man came we were men," says the Indian. Their faith in their forefathers is reverential. They believe they always did what was right. They were kind and true to their friends, but terrible to their enemies.

The Florida Indians are an industrious people. While the fruits of the chase are their main support, they cultivate the fields, raising vegetables, corn and sugar cane. The men make canoes, which they sell to hunters and trappers. Moccasins, baskets and koonti starch, plumes, smoked skins and venison are among their exports. Complaints are sometimes heard that the Indians are killing off the deer and the alligator, which is very true; but alike are the white men and the negro engaged in the same occupation. Before the white race taught the Indian the monetary value of the game of the country, he slew them only for food and clothing. Long centuries had he lived on this continent, but the herds of buffalo were not lessened; nor the vast quantities of game driven to the fastnesses of the forest. Till the white trader came to hunt the game as a source of revenue or for ruthless sport, the Indian knew no such motive.

Like his forefathers, the Seminole is no prohibitionist, but enjoys the fire water, as much as did the savage tribe that greeted the good ship, The Half Moon, in the land-locked waters of Manhattan, three hundred years ago, and drank the first American toast to the intrepid Henry Hudson. 
Since that first great tipple in New York which ended in such a scene of intoxication, causing the Mohicans to name the island "the place of the big drunk," the Indian practices more precaution; and one of their number always remains sober and watches his boozy brother like a hawk. This is the practice of the Seminoles. Before going on a spree, a selection is made of one of the band whose duty it is to stand guard over all weapons and see that no injury is done to any member of the tribe. The "sprees" in which they indulge are too infrequent to warrant them being classed as intemperate. It is opportune at this point to say that only under the degrading influence of whiskey, which the white civilization brings to him, does the Seminole ever show any demoralized condition, and the proper official should see to the enforcement of the laws against selling liquor to these child-like people.

Only a few of the tribe talk broken English. The chiefs disapprove of it on general principles for fear they will talk too much. To keep aloof from the white man, and the white man's ways, is the training of the Seminole youth. Occasionally a few of the tribe leave their marshy homes. These talk sufficiently to do their trading when visiting towns to dispose of their plumes, deer skins, basket work, etc. These products always find ready sale, and when the great day of shopping begins, a "corner" in red calico and fancy colored beads is the result. The squaws have control of their own 


\section{4 THE SEMINOLES OF FLORIDA}

money, when on a purchasing expedition, a fact which makes them very American.

The squaws are about as sociable as the half-wild deer that are petted by the guests of the St. Augustine hotels. As seen in their camps, clustered together, half-alarmed, half-curious, the side glances from their dark-brown eyes seem to utter a protest against the Government's eternal "move on." A more severely pure-minded people are not to be found on the globe. The women are above reproach. Were a white man to insult a Seminole woman by word or look it would be well for that man never to appear in the presence of the tribe again. The Seminole girl who would unwisely bestow her affections would be killed outright by the squaws. In the history of the Everglade Indians only one such case is known and at the birth of the half-breed child the mother was taken to the woods and there hung to a tree by the indignant squaws. The infant was also destroyed. In questioning, as to which of the squaws did the killing, the answer was "All, every squaw." On the principle of American lynch law each hand helped pull the rope.

\section{GENS AND MARRIAGE.}

The Seminoles, like other Indian tribes, are classified by gens. This lineage in the Florida tribe is traced through the mother. The child belongs to the clan which the mother represents. The mother exercises absolute ownership, and should a squaw and 


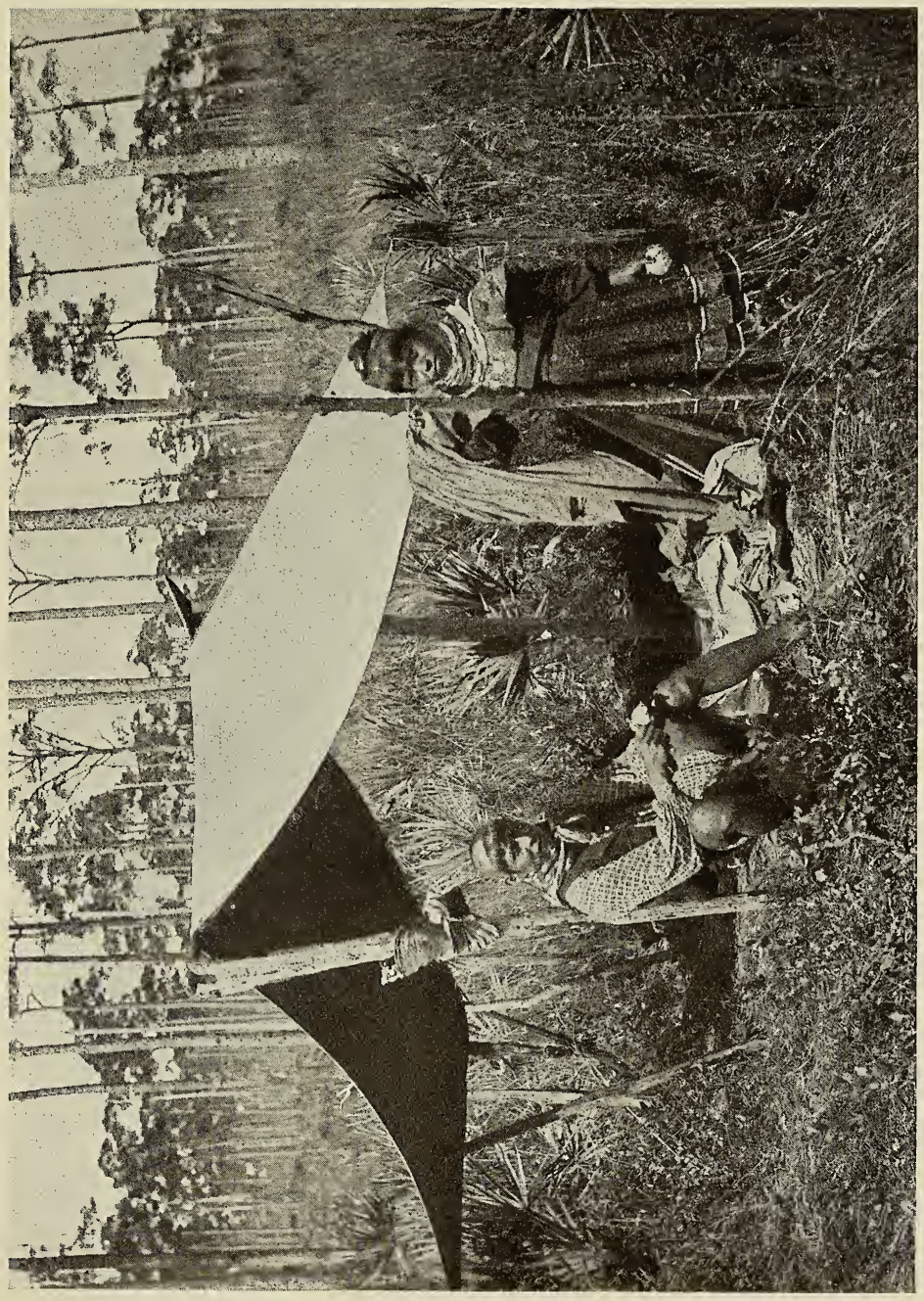

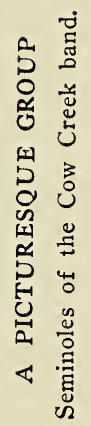

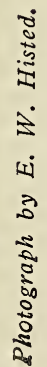





\section{THE SEMINOLES OF FLORIDA II 5}

her husband separate for any cause, the children belong unconditionally to the wife.

Modesty, as the great ornament of women, is taught to the girls, and as she is about to enter into life there is a moral sublimity in the counsel that teaches her to hold an implicit reverence for her husband, but at the same time she becomes a teacher and custodian of her children. One young Indian of our acquaintance is divorced from his squaw. They have one pickaninny now, three years old. Asking the father to give the boy up, and holding out alluring inducements, he replied, "Munks-chay (no), squaw's pickaninny." The gens represented in the Seminole tribe to-day are the Otter, the Tiger, the Deer, the Wind, the Bird, the Snake, the Bear, and the Wolf. Other gens are now extinct in Florida. Thus, in asking about the Alligator tribe, the chief replied, "All gone - long time ago - to Indian Territory." A young brave dare not marry a girl from his own gens, he must select her from another clan. When asking a chief what he would do were he to want a girl from his own gens for a wife, and the girl should want to marry him, he replied, "Me no marry her." The young Indian is shy and bashful in his courtships, and having resolved to marry, conceals his first overtures with all the Indian cunning. His intention is secretly conveyed to the girl's parents, and should there be no objection the young woman is at liberty to accept or reject. No Seminole girl is forced into a marriage. The lover, with permission to woo, shows some token of affection; a 


\section{II6 THE SEMINOLES OF FLORIDA}

deer is killed, and laid at the door of the wigwam. If the present is received the lover is happy. If it remains untouched, he may do as his white brother does, go hang himself, or, as is usual, go seek a more willing fair one. The prospective bride, to show her appreciation of her lover, makes a shirt and presents it to him. No pomp or ceremony is connected with the marriage. The day is set by the parents, the groom goes to the birde's house, at the setting of the sun. He is now her husband, and at her home, he lives for a period. When the young couple build their own wigwam, they may build it at the camp of the wife's mother, but not among the husband's relatives.

\section{BEAUTY AND MUSIC.}

The Indian has a high sense of beauty in woman, and has been demonstrated on several occasions during their visits to the different towns. A Seminole chief was taken to the parlor of a hotel, where a new piano was the exciting theme, to see what effect the music would have upon his savage mind. But the fair-haired performer absorbed his attention, and with a shrug which showed his appreciation for beauty more than for music, he said, "Ugh! white man's squaw heap purty!"

Music is not a genius with the Seminoles. True, they have some songs which are monotone and rhythmical. They are the hunter's songs, the camp songs and the lullabys. The war songs which sent 
such terror to the hearts of the white settlers in Seminole war days they seem to have forgotten. Some of the Indians have natural musical ears, and they are recognized by their people as musical leaders. They have no standard pitch, but start their songs where the natural quality of the voice renders it easiest to sing. The pitch of the song depends upon the individual.

An incident, full of pathos, yet illustrating one of life's parodies, is recalled. It was occasioned by hearing the music of some old familiar tunes played in a gruesome Everglade home. As the picture recurs, one sees a savage tribe - a weird camp scene, with its storm-beaten wigwams in the background and dusky warriors and squaws moving hither and thither in the dim shadows of the camp fire. In the center of the group sat the musician, who was the happy possessor of a "box of music," an organette, which he had recently purchased. The melodies of "Home, Sweet Home," "Hail Columbia," and "Nearer My God To Thee," floated out upon the stillness of the night, telling the story of the white man's inheritance - happy homes, a free Government and an ennobling religion. To the Seminole the tuneful strains contained no more sentiment than the murmur of the brook: for they are a people without a home, without a country, and without a God in the sense of these songs. 


\section{RELATIONSHIP TO THE AZTECS AND EASTERN TRIBES \\ "YAH-VEY, YAH-veY"}

To-DAY, the antiquarian may lay aside his musty parchments of antiquity and in the heart of the Big Everglades study the history of an ancient people through living authors.

"Jah-vey - Jah-vey - Yehovah - Yehovah!" Monotone, yet rhythmical, the brown-faced singers chanted the hymn. Over and over again were the words repeated by the Seminole choir, till the word "Jah-vey," mystical with the centuries past, dwelt with the listener. None but a Hebrew scholar would have caught the word with an understanding of its meaning. The occasion was a Fourth of July celebration when the Rt. Rev. Wm. Crane Gray was visiting the Seminole Mission at Im-mo-ka-lee, situated near the western border of the Florida Everglades.

The Indians, full of confidence and kindly feeling, had consented to sign and here appeared the wonderful, yes, startling, observation made by Bishop Gray. "Jah-vey" is the Hebrew word meaning Jehovah, a word held in such awe by the children of Israel, and as claimed by scholars, too sacred to pass the lips of man, that even its correct pronunciation is unknown. 
To-day in the weird fastnesses of the Everglades, a band of wild Indians chant the name of the Great Jehovah in the Hebrew tongue, a name that is meaningless in its original form to thousands of educated Americans.

When questioned by Bishop Gray as to the meaning of the sacred word, the Indian answered, "God, white man's God." The question now appeals to the scientist, to the antiquarian, and to the theologian. From whence came the Seminole's knowledge of the word?

From its use in the depth of the Everglades, one may work back to the prehistoric ruined temples of Mexico and Yucatan, so similar to those of Egypt; and thus may find in Seminole speech a language link to connect the new world with the old.

Is this single word as verified by Bishop Gray the keynote to the history and origin of the North American Indian?

With a close study of the Seminoles of Florida, one finds a subject mystical with the history of centuries past. We meet in this old-turbaned tribe a history vague, 'tis true, but as interesting as the data gleaned from the hieroglyphics of Mexico, or Egypt, and why not?

While the archæologist delves among the ruins of ancient Egypt, and as he disturbs the inanimate forms of the old Pharoahs, let him pause and like Diogenes of old, shine his lantern in scientific research for the American Rameses. Tracing the proud and invincible Florida Seminole through all 
his wanderings, from the plains of Mexico, we meet him to-day in the confines of the mysterious and weird Everglades.

Reaching Florida in 1750 , under the name Seminole or Wanderers, his history verges into a singularly distressing drama and forms a tragical chapter in American history.

Tracing their lineage, as we may, to the Aztecs of Mexico, the student must find in their usages and customs links that connect their present history with that of the ancient tribes.

In this remnant, proud as the old Montezumas, may the scientist and antiquarian find a history teeming with interest, while the novelist may revel in story, both real and legendary - the most romantic of Indian life that has ever been written.

If we accept the Le Plongeon theory of prehistoric Mexico, as well as Professors Holmes and Seville's research of Mexican antiquities, we must note the relationship between the early Central American civilization and the Ancient Egyptians; and that the builders of the pyramids and temples of Mexico and Yucatan were closely allied with the architects of the Cheops.

After the conquest of Mexico by Cortez in I 5 1920, the Muskogee Indians left Mexico and gradually traversed the country till in $I 620$ we find them in Alabama, where they added other bands to their ranks. The British name them Creeks, from the many small streams that traversed the country.

Thus the great Muskogee tribe of the Mexican 
Empire vanquished by Cortez became one hundred years later the Creek Confederacy, from which branched the Seminoles.

It will take no great stretch of fancy to suppose that before the mysterious chain of migration the Aztecs and the early Egyptians were allied. As we study, to-day, the frail remnants of the vanishing Aborigines in the heart of the Everglades, may we not find a coincidence of usages that at least give abundant food for speculation, and the resemblance of the present Seminole to the ancient Egyptian suggests strong points of similitude to that of the old Israelites, and a common origin for the North American Indian and the older tribes, whose magnificent wrecks strew the borders of the Nile?

Prescott in his history of Mexico refers to some traditions of the Aztecs, as bearing a singular resemblance to those found in the Scriptures. More or less does one start with surprise and awe as he notes in the Indians of Florida a strict observance of those customs as well as religious beliefs as laid down in the book Leviticus.

The similarity existing between the ancient Egyptian principles and that of the Aztecs is conceded by scholars, and when the Florida Indian follows so closely these old religious rites, with the theory that the Florida Seminoles are traceable to the mighty Aztecs, may we not feel a pride in these red children of the forest homes and while it is yet possible preserve this almost forgotten remnant?

To-day the student may study, in the swamp fast- 


\section{I22 THE SEMINOLES OF FLORIDA}

nesses, the history of an ancient race, through the present-day Seminole.

Around the hereditary chief Tallahassee is the authority for the government of the Cow Creek band. He is the honored chieftain, whose duty it has been to teach to the younger generations the traditions of his ancestors. "My grandfather, old, old man, tell me, me tell my boys." The stories never diverge - the same to-day that were told one hundred and fifty years ago, and different slightly from the teachings of the vanquished Muskogeeans of the Mexican Empire.

In their weird camps, by a glimmering light from the camp fire, is instilled into the youth the laws of the old turbaned tribe, laws startling in the rites they contain. A brief reference to a few of these observances must convince that there is at least a keynote for a chapter that must prove both interesting and valuable to science.

In the head dress of the Florida Indians, oriental in its effect, one quickly recognizes a perfect imitation of that as worn in I80o B. C., as shown in the statue from Tel Loh (showing early Akkadian type).

Passing through the realms of history, covering a period of 3,000 years, in I 563 we find Le Moyne's delineations of the turban, now worn by the Seminole chieftains. Likewise might the dress of old Tallahassee in his chieftain regalia be mistaken for the costume of the patriarchs in the days of the Pharaohs, when the long tunic embraced by the 


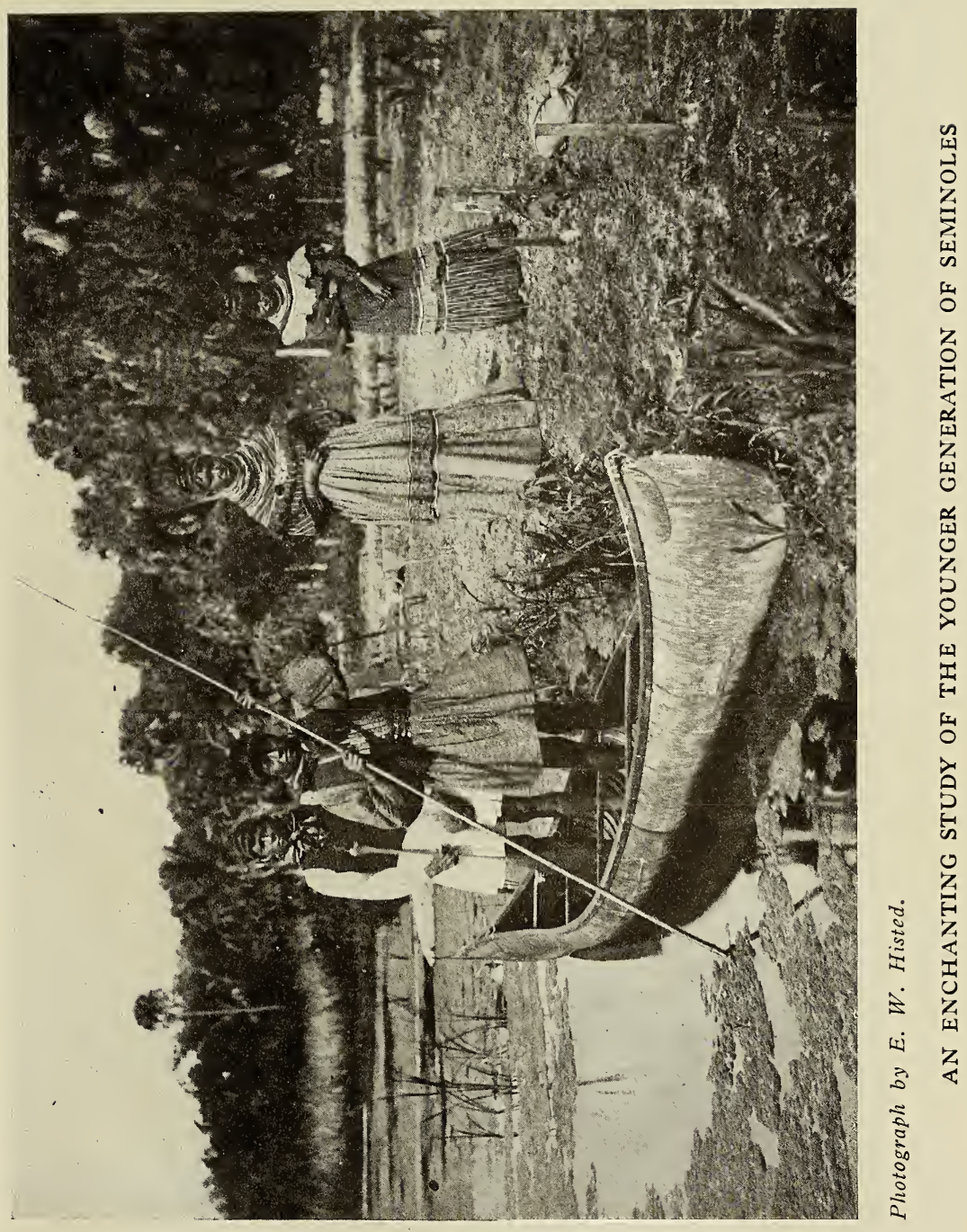



brightly embroidered sash, with its heavily-tasseled belt, made a picturesque attire.

Not the least startling, after thirty-four centuries, do we find the Seminole observing the rigid laws of health as laid down to the Children of Israel after the Exodus. With reference to the preservation of health, we find in the Scriptures, that those affected by disease were separated from the tribe and as health returned, we read, Leviticus I5: I3, "Then shall he number himself seven days for his cleansing and wash his clothes and bathe his flesh in running

- water and be clean." Verse 7, "And whosoever toucheth the flesh of him shall wash his clothes and be unclean until the evening." Note the following: On a recent visit to the Seminole camps, and after receiving a warm welcome from the squaws and pickaninnies of former acquaintances, a solitary figure was observed sitting in a small detached wigwam. Approaching for the purpose of shaking hands, from all sides came gesticulations and dissenting tones from the squaws, and feeling that the woman was a prisoner or taking some kind of punishment, we passed on. During a visit of three days at the camps, the squaw was kept aloof from the band, receiving all necessary attention with the kindliest spirit, but fulfilling the law of Moses, as recorded in Leviticus, "And she shall be apart seven days and whosoever toucheth her shall be unclean."

The Aztecs made crimes against society capital; among their registered laws, adultery was punish- 


\section{I24 THE SEMINOLES OF FLORIDA'}

able, as with the Jews, by death. The same laws hold good among the Seminoles to-day.

Marriage laws are held sacred, but divorces are permitted where some incompatibility of temper is found. This is done after the manner of the old Jews - " out of mercy to the woman." Either party may marry again, but the marriage must meet with the approval of the leaders of the band.

Taking up the question of land tenure, one sees the similarity between the Everglade Indians and that of the ancient tribes.

There tribal organization being a socialistic and communistic order, it is not their policy to encourage individual land holdings.

Socialism finds its greatest example among the Seminoles and they realize freedom in a greater degree than can possibly be found in any community governed by man-made laws. They do not violate any teachings of the tribe and are honorable and upright in their dealings with one another and equally so with the white people with whom they come in contact. Their law allows of individual occupancy of land and the individual rights are respected, but the Indian is not allowed to acquire title.

The Seminole, like his Aztec ancestors, shows an honorable contrast to the other tribes of North America, in the treatment of the women. No severe agricultural labor is imposed upon them and the consideration shown them by the men would do credit to a high civilization. Those who know some of the habits of the Florida Indians 
'(Seminoles) are cognizant of the fact that they will not eat the green corn until the second day of the annual feast.

On a visit to the camps, old chief Tallahassee was invited to join his white friends at dinner, and as he was offered a roasting ear, he said, "Me not eat green corn, Shot-kay-taw (Green Corn Dance), eat plenty." Pointing to a small patch of corn from which the ears had been stripped, he said, "Squaws eat corn plenty, men no eat," and as we read Leviticus, $23: 14$, the thought comes: Is the law, though divested of part of its meaning, being fulfilled to-day by a band of wild Indians?

"And ye shall eat neither bread, nor parched corn, nor green ears, until the self-same day ye brought an offering to the Lord."

Another link is a feast day which seems to correspond in its rites to the Day of Atonement on old Jewish days. It is of peculiarly solemn character and takes place in cycles. The sacredness attached to the assembling of the band prevents little insight from the outside world.

With only an oral tradition, with their unwritten but priceless history of an ancient race, with the white man daily encroaching on their last domain, the time for studying this primitive people in their purity will soon be over, and of their customs and usages, where is the Edipus at this day who shall solve the riddle of their origin? 

The Seminoles at Home 


\section{SEMINOLES AT. HOME}

\section{The Everglades}

The characteristic of the Seminole is to make his camp in some secluded spot where the white man would least expect to find his habitation.

The peculiar physical formation of Florida makes this very possible. The Everglade region, which is the immediate environment of the Seminoles, is a watery prairie, with here and there high points of ground, and because land-grabbers, corporations and state officials are already clamoring for these watery wastes, and selling thousands of acres from paper plats, with the land still under water, a more detailed description of the Everglade region would be better appreciated. This vast region contains about 4,000 square miles of marsh lands and tropical forests, interlaced with thick clustering vines and is the greatest area of unexplored country in the United States.

The accounts of the interior of the mysterious swamp is to be found only in dim tradition or Indian legends.

However fast the door of the swamp may be locked, it opens quickly enough to whomsoever carries the key. The Seminole is the true key-bearer and with moccasined foot he enters when and where he will. 
A writer, in a Miami paper, gives the following interesting account of his approach to the Indian camps :

"Traveling through this aquatic jungle in a light canoe, the motive power of which is plenty of muscle, a broad-blade paddle and a push pole about eighteen feet long, we enter a trackless waste of saw grass and water, with scattering islands and lagoons, channels running in all directions. These channels often terminate in what is called a pocket and then trouble begins, as these pockets are so shallow that a canoe or skiff has to be pulled by rope or pushed by hand through the mud and grass, until deep water is found. All signs fail in the Everglades, as often to go north you will take the other three points of the compass.

"There is nothing quite so aggravating," continues the writer, "as to get sewed up in one of these pockets, in the open saw grass with deep water in plain view and fine shady trees to welcome you, but tired and disgusted you stand as high as possible in the canoe and see only one chance in a hundred to find the right channel to go through.

"There is no use for a compass, and it is a waste of time to think about it. There is a sure thing of going overboard in the mud or going back and starting over again.

"When the water is high the trouble is not so great, but when it is low, the traveler can lay aside his Bible, quote a chapter from Dante's Inferno, and plough through the mud until his energy is exhausted 


\section{I28 THE SEMINOLES OF FLORIDA}

and wonder if Dante ever heard tell of the Everglades."

The channels running through these Glades are alive with fish, while the saw grass ponds provide homes for thousands of alligators. The myrtle and cypress clumps are the winter homes of the heron and migratory birds.

From this vast morass, with an elevated position, and a rare atmosphere, the view that would meet the eye would differ from any other on the globe. Ballou says: "A thousand square miles of saw grass would be seen spreading out in the shape of an artist's palette. Towards the end would be seen a series of little inland lakes, fed by minute rivers. Interblending with the lakes, thousands of islands would be visible, far beyond the saw-grass sea. The flutter of bird life would be like the milky way, and the swarm of insects like a distant sand storm on the Sahara."

Bordering the sedgy lagoons, are dense cypress forests, with here and there cabbage palms, Indian rubber and mangroves, while tangled vegetation weaves itself in chaotic style over underbrush and tree. These are the primeval woods of the United States. To be lost in these great marshes means more than death. They are the paradise of the serpent and the alligator. It is said in old slavery days, slaves who ran away to the swamps, were entered on the books as dead.

Except the few points touched upon by adven- 


\section{THE SEMINOLES OF FLORIDA' 129}

turous botanists and hunters, this entire region has remained terra incognita until within the past two or three years, when the subject of drainage has caused deeper and more scientific investigation. These explorers have brought interesting accounts of the great swamp.

The subject of drainage of this vast aquatic jungle is causing many disputes and many opinions, but under the Legislature of 1897 , with the imperturbable Governor Broward in power, the work of drainage was begun.

Those engaged in the reclamation of this rich soil look upon the enterprise as being one of the most colossal of American ingenuity and one that will made the Okeechobee region the Egypt of America. While it is not the object of the writer to enter into the question of reclamation - still, the thought comes, "Is it worth while to make this region fit for habitation?"

The Florida Everglades Land Company who are carrying on the work of drainage on scientific rules, in the employment of government experts and following natural laws, show in their practicable demonstrations, the great benefit the redemption of submerged Florida will be, not only to the South, but to the whole country.

Prof. H. W. Wiley, Chief of the Bureau of Chemistry, U. S. Department of Agriculture, says of this great State question of drainage: "There is possibly no other body of land in the world, which pre- 


\section{I30 THE SEMINOLES OF FLORIDA}

sents such remarkable possibilities of development, and with a depth of soil averaging perhaps eight feet, it reaches beyond the limits of prophecy."

Then, when enterprise and capital enter the last home of the Seminole, converting the tropical swamp into golden Everglades, may we not pause to ask, "Is there not room enough for this remnant of a helpless people in the country to which they have been driven."

Here in the heart of the Okeechobee country, we find the only remnant of our native American Indian, in his original simplicity, meeting in the huntinggrounds of his ancestors the mighty power of Capital, Industry and the Twentieth Century methods of progress. Shall we wrest from him every vestige of this last foothold in Florida, his last resting-place in his direst necessity?

The ultimate end of the Seminole should be, to be civilized and Christianized and assimilated into the present status of the American citizen. While today reclamation looks a calamity to the interests of the Florida Seminole, it is possible under the direction of an overruling Providence to be made an almoner of benefit. There is at this time plenty of land for both interests. It becomes the duty of the United States Government through its Indian Department and the friends of the dependent Seminole, to see to it that land sufficient for their use be left in the Okeechobee country, with Uncle Sam's signboard reading, "Penalty to Tresspassers." 


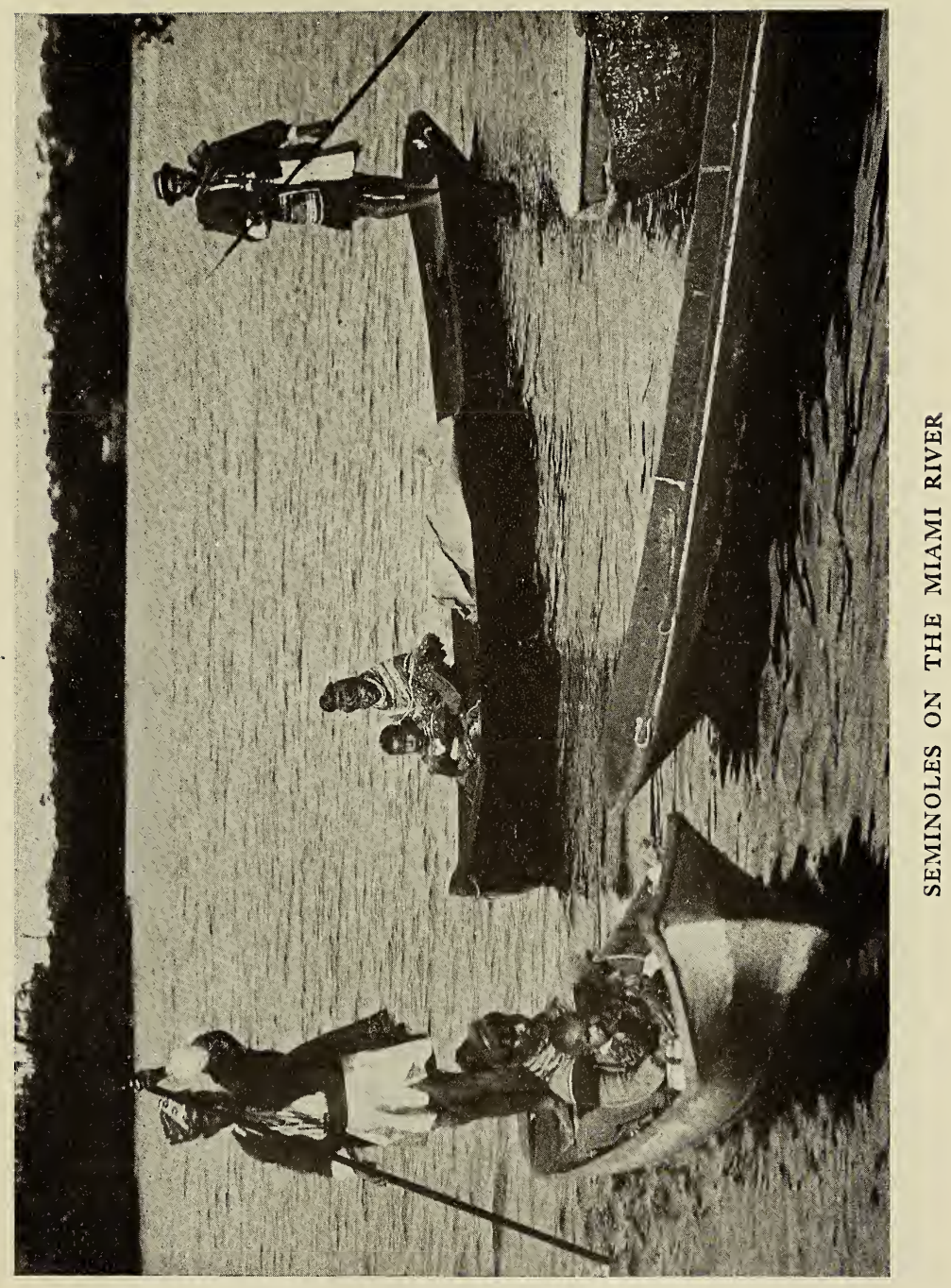



Let us, as a great American jury, pause in our mad scramble for dollars, and consider our brother in red. As we plead for these relics of the warriors of old, we ask, "Why molest them? They are brave, selfsupporting and piteously plead to be let alone."

Over seventy-five years ago an officer of the Fourth Artillery wrote in a Charleston paper, "Can any Christian in the Republic pray for the continuance of blessings, when he is about to wrest from the unhappy Seminole all that the Great Spirit ever conferred upon him?"

On the larger islands of this tropical swamp are found the fertile hommocks, the home of the Seminole Indians. Approaching such a home one sees marks of labor; a clearing is made, the wigwams built, sugar cane, sweet potates and squash are growing. Chickens and pigs run about and an air of contentment pervades all.

A visit to these Indians is still fresh to memory. After an arduous journey, the village is reached. It was the occasion of the Green Corn Dance and preparations were going on. The hunters were out for game, the corn was ripening and an air of festivity was all around.

Dogs barked as the white guests approached, but a commanding Seminole reprimand soon drove them away; pickaninnies came around with timid advances, squaws greeted with handshaking. A wigwam was built for us by the hospitable hands, and the visitors were assigned to this part of the camp. 


\section{I32 THE SEMINOLES OF FLORIDA}

What a world of interest, both romantic and tragic, hangs around the wigwams of a Seminole family!

To Tallahassee was assigned the greatest part of the entertaining, and he it was who directed the movements that would add to the pleasure of the guests.

Without giving thought to it, the team was hitched to a pole that stood in the open. It proved to be the festal pole for the dance, and the spot was sacred for that occasion, but the innate courtesy of the old chief prevented his showing any offense, and in the morning he waved his hand in the direction of the horses and asked, "Horses, you want 'em there?" Learning what the pole was for, we were the ones to beg pardon and feel chagrin. Then came the attention to the guests, in showing around the little fields, telling the names and kinship of the various members as they came into camp. This devolved on Tallahassee, and the honor was two-fold.

As the shadows fell and the camp fire flickered, the old chief regaled the company with history dating back one hundred and fifty years. The old patriarch and warrior rambled on in low monotone, living over in dreamy reminiscence his hunting days, and with the record of seventy bear, to say nothing of panther, deer 'coon, possum and turkey. How the enthusiasm of the twentieth century hunter was put on fire.

As the old chief drew closer his tunic, we asked, "Tallahassee, last winter, cold much; Kissimmee 
City, ice come; what you do?" A young brave spoke up, "Tallahassee old, get cold heap, blankets put on him and big log fire make." Then came the jokes as told by one member on another and how these children of the forest would laugh as the tales were recounted. They are children only in mind, but full of discernment and strong in character.

A present of a picture containing Tallahassee's picture had been sent to the old chief a year before, and this must now be brought out to show the visitors. Spelling and copybooks were the occasion of much comment and much praise from the white friends. The older Indians say, "Me no writeold too much. Little Tiger make letters by-and-by; write good - keep store."

The utensils that hang around the wigwam would do credit to many a white family; they have buckets and pans of agate ware, and well made wagons purchased in Jacksonville.

The hum of the sewing machine was heard in the wigwams, being used equally well by both men and women.

While the patient Seminole is at the mercy of the white man, and each day becoming more helpless, he is still proud as the old race.

A purse of ten dollars had been made up for one family where the husband had died, but with the suspicion that the money was from the Government, the older members held a talk with the result: "Money no take 'em. Squaw no want 'em." With mouth-watering glances the little ones on the same 


\section{I34 THE SEMINOLES OF FLORIDA}

occasion refused candy and cakes; they had been forbidden to accept what the old Indians believed was from Washington - the home of the Big White Chief. (This was at the time the Indians had been alarmed by cowboys telling them the Government wanted them for Arkansas.)

To-day in the forest home of the Seminoles, where yet gleams the council fires, and within a mile of the palmetto thatched camp of the Osceolas, the big dredges groan an accompaniment, as it were, to the echo of the throbbing hearts, the death song, the Recessional, of the Seminole.

Dynamite blasts shake the very pans and kettles hanging around the wigwams and, while this monster of a machine destroys the only home of the tribe, is the time not ripe for decisive action in the protection of these wards of Florida?

A visit to the Seminoles' camp reveals many interesting little things which touch the heart and evoke the sympathy of the observer. The affection displayed by the stern-faced father, when coddling his pappoose, convinces the most skeptical that in the fastnesses of the forest "The heart of man answers to heart as face to face in water," whatever the skin it is under. Old Tom Tiger, without question one of the most ferocious-looking of the Seminoles, would take the baby-boy from its tired mother's arms and softly croon a lullaby, swaying the pappoose backwards and forwards in his great strong arms till the little fellow would fall asleep.

Another instance of parental affection, as given by 
the Rev. Clay McCauley in his report on the Seminoles of Florida to the Bureau of Ethnology, is full of touching interest. While the incident occurred many years ago, and the little boy is now grown to manhood, still it cannot fail to reach the heart of the reader. We give it in the writer's own words:

"Tallahassee's wife had recently died, leaving him with the care of six boys; but the strong Indian had apparently become mother and father to his children. Especially did he throw a tender care about the little one of his household. I have seen the little fellow clambering, just like many a little pale face, over his father's knees persistently demanding attention, but in no way disturbing the father's amiability or serenity. One night, as I sat by the camp fire of Tallahassee's lodge, I heard muffled moans from the little palmetto shelter on my right, under which the three smaller boys were bundled up in cotton cloth in deer skins for the night's sleep. Upon the moans followed immediately the frightened cry of the little boy, waking out of bad dreams, and crying for the mother who could not answer; ' Its-Ki, Its-Ki,' (mother, mother) begged the little fellow, struggling from under his covering. At once the big Indian grasped his child, hugged him to his breast, pressed the little head to his cheek, consoling him all the while with caressing words, whose meaning I felt, though I could not translate them into English, until the boy, wide awake, laughed with his father and was ready to be again rolled up beside his sleeping brothers."

Where the Seminole is hospitable is around the camp fire and the "Sof-ka" kettle. "Hum-buxchay" (come eat) is his salutation. The kettle is 


\section{I36 THE SEMINOLES OF FLORIDA}

placed in some covenient part of the camp and at the meal hour the members of the household sit around it. A large Sof-ka spoon rests in the pot, and is handed from one to another, each taking a single mouthful. A fastidious taste might shrink from using the large spoon, but to affect such taste would be to offend mine host. Sof-ka is the Seminole standard dish, and is simply a stew made by cooking the meat in a large iron pot, and thickening with meal, grits or vegetable. Sof-ka corresponds in its importance with the Seminole to "frijoles" among Mexicans. The Indians observe a regularity in meal hours, yet at most any hour the Sof-ka kettle is ready for those who may come in from the chase enhungered. So plentiful is game that it is a common sight to see a saddle of venison or a wild turkey and perhaps a duck roasting before the fire, and, as appetite prompts, any member of the camp may help help himself to the savory roast.

The Seminole pickaninnies are healthy, goodnatured little toddlers, and show no more savage spirit than do their little pale-faced brothers. They play with bows and arrows, make dolls and playhouses, revel in mud pies, roast the small birds they kill before a "spit fire," and play they are roasting wild turkey. They rarely cry, as they are taught from infancy to show no such weakness; they must obey the slightest command of their elders. The little four-year-old is taught to assist in the duties of the camp. He can carry water, gather wood, watch 
the little pappoose, and learns thus early that he is an important feature in the tribe.

The boys are allowed to handle no weapons until old enough to use them successfully. When an Indian boy is taught to use a Winchester and returns from the chase with his first deer, favors are shown him by the elders, tokens are presented and he becomes for the time the young Nimrod of the tribe.

Seminole children are on the whole very much like other children, some bright, some good, some perverse, all exceedingly human. With the discipline already instilled into their natures, and education, first for the heart, and then for the mind, added, success would be assured. A Seminole luxury which serves as a target as well as food, is the fruit of the climbing pumpkin vine, which is often seen among the branches of the trees. When wanted a welldirected rifle ball cuts the stem and the pumpkin drops to the ground. This was the sport enjoyed by the troops during the Seminole war.

The absence of all earthenware is noticeable in a Seminole camp. The Seminoles say, "Long time ago," their race made earthen pots, but white man's kettle "heap good," and they have long since ceased to work in clay. All through Florida pieces of pottery are found in the sand mounds. In the pine forests where the land is good for cultivation, broken pottery is frequently dug up out of the ground. These forests have grown over this land evidently since it was cultivated by former races. The pottery 


\section{${ }^{3} 8$ THE SEMINOLES OF FLORIDA}

found in parts of Florida, is said by those having made a study of the subject to resemble the Aztec pottery to some extent.

One of the peculiarities of the Seminole man is the number of shirts and handkerchiefs he wears at one time. An instance is related where a white man in company with Billy Ham went out deer hunting. Emerging suddenly from the thick forest, some deer were observed feeding on the Savannah in front of them. The Indian was dressed in the bright colors of his race, and stealthily slipping back into the shadows of the tree, he began to remove shirt after shirt and untie handkerchiefs from around his neck. As each article was removed, the Indian became less conspicuous. After divesting himself of six or eight shirts and eight or ten handkerchiefs, the Indian and his costume now blended with the surrounding objects. His dusky form was in perfect symphony with the dead leaves and grasses, through which he silently crept toward his prey. The Indian prefers to make sure of his game by creeping upon it. He can advance to within a few feet of a deer. The deer, while feeding, is always on the alert for an enemy. If it sees nothing moving it will not be alarmed. This is where the strategy of the Indian comes in. He stops just before the animal raises its head. The lifting of the head is always preceded by a movement of the tail, hence the cunning Seminole watches the tail and knows when to be still. 


\section{ALLIGATOR HUNTING.}

At this point, a detailed account of an alligator hunt with the Seminoles may prove interesting to the huntsman who may scan these pages.

Some tourists hire the Indians who frequent civilization to guide them in hunts, but it is poor Lo's idea to show the white man his hunting; and he will take him around and around, always keeping out of sight of game, with a cunning that would do credit to a Connecticut Yankee.

Possessing that talisman, friendship and confidence of the Seminole chiefs, our hunter arranged for his first alligator hunt. To simplify the account of the tenderfoot's experience, we give it as related to the writer.

"Taking the little steamer Roseada at Kissimmee City, a two days' ride landed us at Bessenger, where I was met by an ox-cart, driven and owned by the Seminoles. A ride of forty miles, slow but sure, took us to the Indian village. Here I was met by dogs, pickaninnies, squaws and braves. With time limited and eager for the hunt for big game, I rested but a few hours and then announced myself read to hi-e-pus (go).

"In a cypress canoe, poled by Chief Tom Tiger Tail, we turned our boat toward the interior of the Everglades, and for three days traveled over as wild and weird a land as Stanley ever explored in Darkest Africa.

"Poling through water lilies, tall grass and 


\section{I40 THE SEMINOLES OF FLORIDA}

overhanging branches, frequently getting stuck in the shallow water and marsh, all gave more zest to the square mile than a hundred hunts in the North could.

"Reaching the objective point of our trip, the chief tied up the canoe, and after a hearty repast, we were ready for the alligator hunt. No game laws obstructed our progress, no sign boards read, 'No Trespassing,' and soon we were equipped for the night's hunt.

"With a bullseye lantern attached to my cap, I took my seat in the bow, while Tiger Tail, standing in the stern, propelled the canoe with long, dextrous strokes. Reaching a deep bayou, where the Seminoles kill hundreds of alligators each year, I was directed to throw the light quietly over the water, and the presence of the saurian would be revealed by the reflection. Silently, slowly, our canoe cleaved the dark waters. Truly, the scene was worthy the pencil of a Doré. A moonless sky, a wild expanse of bleak water, a canoe propelled by a savage, splendid and careless in his unconscious grace, and as silent as the oarsman of the River Styx. Soon the dismal solitude was broken by our entrance into the alligator haunt. With stealthy glide through the still, dark water, we were soon aware of being near a very large 'gator - the two balls of fire shining in the darkness told the tale. Without a ripple the Indian glided his canoe within ten feet of the monster, and a shot between the eyes from a .38 Winchester blew the top of his head into small pieces. Before the 


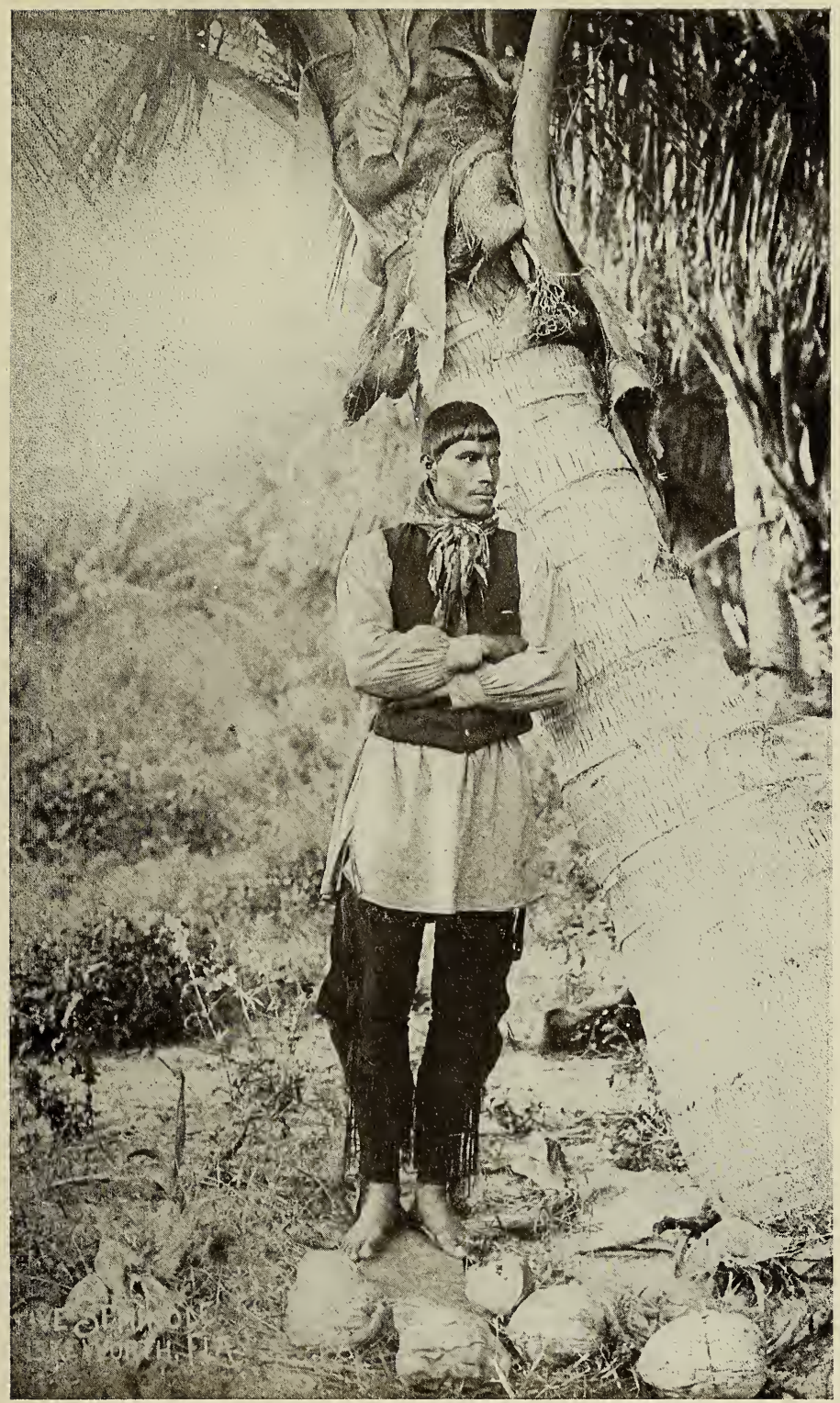

TIGER TAIL, A REPRESENTATIVE SEMINOLE

In picturesque harmony with the land of the cocoanut. 

reptile could flounder out of reach, the carcass was grabbed and pulled into the canoe by Tom Tiger, and the spinal cord was severed with an axe to prevent any future trouble.

"At the first approach of our light the alligators gazed at it in the most fatuous manner, allowing the boat to approach within a very close position; but after one of their number had been slain they commenced a vibrating roaring, playing see-saw with their heads and tails and slowly rolling forth their feelings in deep, thundering tones. To me, there seemed to be 500 alligators in that body of black water that night, and each and every one seemed to turn his burning eyes on my little searchlight and they shone like stars. I could easily tell a big fellow by noticing if his glaring balls were close together or far apart. After killing four or five I called out 'Enough!' The picture was growing too gruesome. The quivering mass of reptiles in our canoe made me think longingly of home. 'Ungah' (all right) from the Indian reassured me, and the canoe was turned toward camp. During the evening the Indian chief had killed an eleven foot 'gator, and so lifeless did it seem when dragged into the canoe that it was not considered necessary to cut the neck and back. The extraordinary vitality of an alligator keeps it from dying for some time, the nerves often living for several hours after the head has been severed. Our canoe was loaded to the water's edge, with the large saurian in the bottom. Presently a low breathing greeted 


\section{THE SEMINOLES OF FLORIDA}

my ears; soon it grew louder, and a faint motion could be felt in the boat. Still I remained passive, the Indian poling through the deep, tortuous stream. I had instinctively drawn my feet up, when the great mouth, which was toward me, opened and began snapping angrily. His body began to writhe and twist and wriggle, which set all the other alligators in motion. The situation was growing critical and dangerous, when Captain Tom, perceiving the trouble, came to the rescue with his axe and none too soon, for the huge saurian began lashing his tail from side to side, and had the Indian been less skillful in handling the canoe we certainly would have been turned overboard. With the hideous cargo silenced, the Indian always cool and nerveless, looked up and with a humorous twinkle in his eye said, 'White man 'fraid ojus' (heap)."

BEAR HUNTING WITH THE SEMINOLES.

Under the head of American Sport, the following story of a "Bear Hunt with the Seminole Indians," appeared in the columns of the Asian Sporting Nerospaper of Calcutta, India.

The story had been accepted from the pen of the writer by Forest and Stream Publishing Company of New York, and because our British hunters of lion and elephant fame had appreciated an American hunt sufficient to scissor it (neither giving credit to the author nor to the American journal), the story is here appended: 
"Hunting the black bear in Florida is a sport to which few are introduced. This bear is not fierce nor dangerous, but still he is big game, and a bear hunt is always full of incident and excitement. About ten miles from Kissimmee, is a cypress swamp - it is an aquatic jungle full of fallen trees, brush, vines and tangled undergrowth, all darkened by the dense shadows of the tall cypress trees, and full of moccasins and alligators. Running through the swamp is a chain of islands. Here is a field for sportsmen, and here live unmolested a whole colony of the bruin family. Hunters hear their growls, and numerous fresh tracks show where the night marauders have entered the hommock, where they feast on wild honey, huckleberries, the cabbage of the palmetto and the wild orange. They seldom come out to expose themselves during the day, hence they are rarely captured, and in consequence are on the increase. Settlers frequently report depredations on their hogs; but bruin is safe in his swamp home, for without dogs trained to hunting bear, even if he were surprised, he would quickly make his escape into the jungle.

"Of all game of the forest bear meat is the favorite dish of the Florida Indians; squaws, pickaninnies and dogs revel in it. With this knowledge, it was an easy matter to secure a party of Seminole chiefs and their trained dogs for a bear hunt. The auspicious day arrived. This picturesque hunting party came striding into Kissimmee as unconscious and statuesque as bronze figures of Mercury. The 


\section{I44 THE SEMINOLES OF FLORIDA}

party was led by Chief Tom Tiger, following after in Indian file was old Chief Tallahassee, Doctor Tommy and Little Tiger, while trailing along by their sides were the formidable looking dogs. Dressed in their holiday attire, with new leggins and moccasins, bright calico shirts, a half-dozen red handkerchiefs around their necks, crowned with the immense red turban, the emblem of their race, with knives and cartridges in their belts and Winchesters at their sides, the Indians attracted as much attention as a Presidential party.

"If ever men deserved the name of Nimrods, it is these sons of the Everglades. Even Little Tiger, a boy of twelve, with his fine rifle, could put to shame many a skilled marksman. But on to the chase. The souls of the red men seemed to leap into them at the thought of the sport after bear, while the hounds barked gleefully, so with hasty preparations our hunting party started for the Reedy Creek jungle. At this point we will turn the story over to the tenderfoot, that the reader may better follow the chase.

"As we reached the hommock, which has been for years a veritable elysium for the bears, the dogs seemed to become possessed of a very spirit of unrest; soon they struck a trail. "Lo-co-see ojus" (bear plenty), exclaimed Captain Tom Tiger, as he observed the numerous cabbage palms with their buds freshly torn out, as well as the conduct of his dogs, and with a word of command to the hounds, he started. The rest of us followed, till we struck 


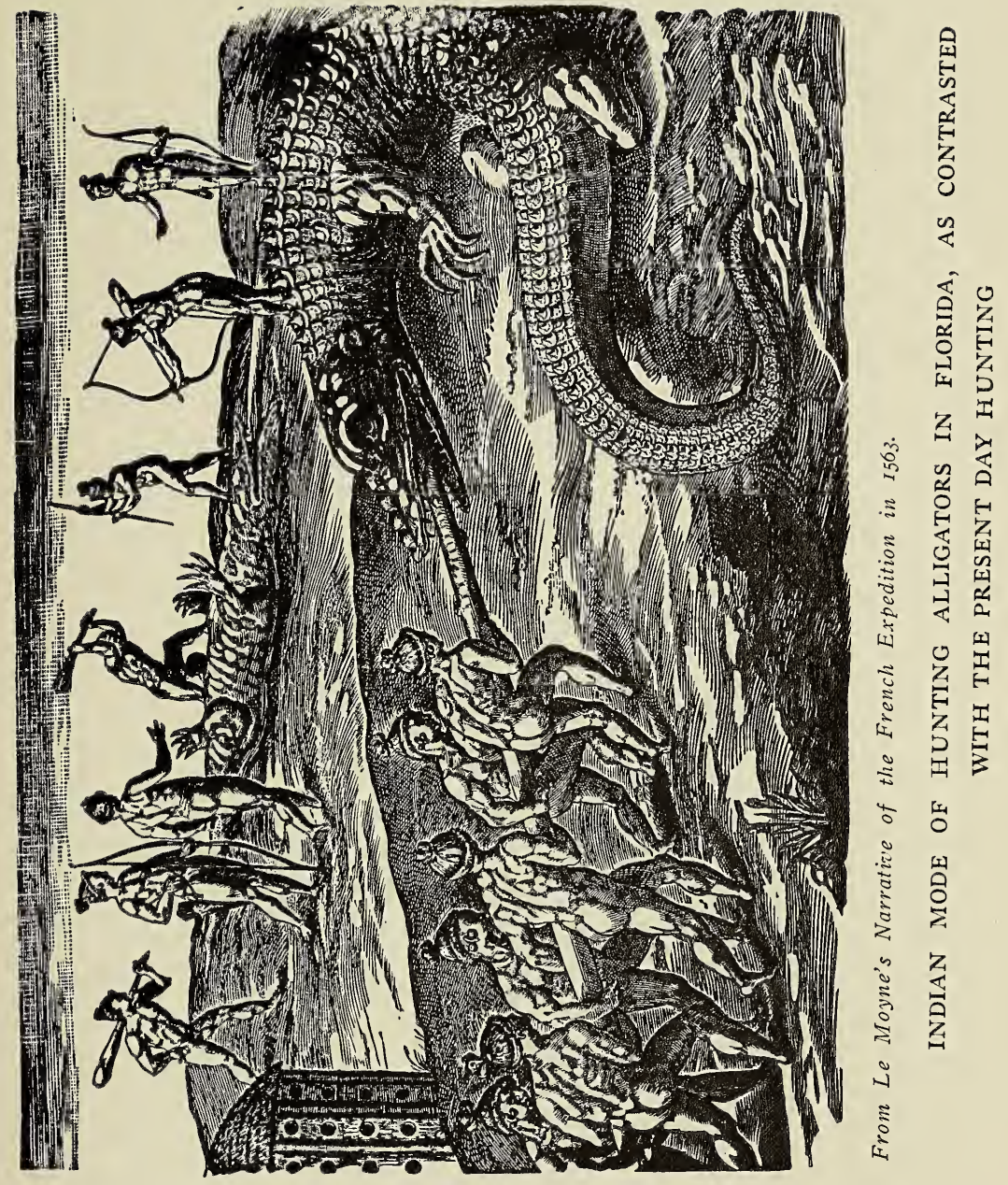



a marsh heavily timbered with cypress, which grew so close that sun's rays could not reach the earth. It made a dark, damp and dangerous ground to enter. The dogs were now running with broad scent, heads well up and throats wide open. If ever there was a sound sweet to the hunter's ears, it was the baying of five hounds close on bruins trail. With nerves on a tension we rushed along, with gun carried at ready. On swept the riot. The Indians yelled as only Indians can, and the tenderfoot brought up the rear. A hunt in a Florida jungle, pulling through soft mud, climbing over logs, pushing through vines, sprawling on hands and knees through the tangled, matted undergrowth, expecting or fearing each step we would strike a moccasin, are the penalties paid for the romantic, adventurous hunt with a Seminole Indian. At last the supreme moment arrived; the leading dog had reached the bear, and soon the five dogs and the bear were having a vigorous rough and tumble fight. We were in good hearing distance, but traveling was very difficult, and our progress was slow. The Indians' cry, 'Yo-ho-ee-hee, Yo-ho-eehee!' to the hounds, made them fight furiously, so much so that bruin broke from cover and started on the chase just before we reached shooting distance. Further into the woods the chase led. Soon the sound of the pursuing dogs ceased, much to our surprise. We appealed to the nearest Indian for an explanation. 'Lo-co-see (bear) climb tree,' was the brief reply, and later, when we reached the dogs, 


\section{I46. THE SEMINOLES OF. FLORIDA}

they were running wildly around on the bank of a dark creek. We were again at a loss to comprehend the situation, until we were shown by the Indians a leaning tree, the top of which reached to the further side of the creek, over which bruin had safely passed. 'Lo-co-see-hiepus' (bear gone).

"Three hours' tramping through the swamp and hot sun had taken all the enthusiasm out of us, and we were ready to play quits, but the stalwart red men had defiance in their faces as they said, 'Big lo-co-see; fight heap; Indian kill lo-co-see to-day.' Away to the left the brown legs of little Tiger Tom could be seen twinkling through the foliage; he had found some fresh tracks of a cub, and in his eagerness to capture a baby bear he proved a similar nature to his little pale-faced brother. But the stern hunters had no time for a cub, and soon started for old bruin, who by this time had crossed the marsh and gotten into a tree on the opposite bank, and by this trickery put the creek behind him. This did not daunt a Seminole Indian. Wading the shallow part of the creek, with water to the armpits, again cooled our ardor, but safety depended on not losing sight of the Indians, as we were miles in the swamp, and with no hope of finding our way out without the guidance of our red pilots. At last the bear was driven to a small island and surrounded, the island covered with tall grass and weeds hiding both dogs and bear. The dogs grew furious, and several times forced the bear to stand and fight, and such a battle as it was; the dogs didn't hesitate to 
take hold of old bruin, and as a result were badly lacerated from the blows of her powerful paw. We closed in and our game was in a trap. The Indians were in their future heaven; but the tenderfoot was getting very shy of being hugged. Bruin, now finding herself cornered, made a break for the open, and as she emerged from the tall grass, with the dogs at her heels, she met the stalwart figure of Tom Tiger. Rising on her hind legs, with open arms, she made one dash for him, when stepping back, in a cool and deliberate manner, he pulled the trigger of his 'scatter' gun and emptied both barrels into the bear's side. This ended the chase, and a happier set of Indians the world never saw. Immediately they drew their knives and commenced skinning the bear. As the skin adheres very tenaciously it should be taken off at once, as it comes off much easier; besides, it is difficult to scrape away all the fatty tissue after it cools, and wherever any remains it rots the pelt. "The Indians' method of educating their dogs for hunting bear is well worth knowing. They take the gall of the bear and thoroughly saturate the nostrils of the young dog. This is excruciating pain to the dogs, and they howl and whine for hours; but it makes 'bear dogs' out of them, perfect on the trail, and this is the point with the Indian.

"The huge carcass of bruin was divided and each Indian carried a load to camp. A fire was soon built, and a huge chunk of bear meat was thrown on the coals. All night long they cooked and ate; the tenderfoot getting into his hammock beneath the 


\section{I48 THE SEMINOLES OF FLORIDA}

bough of the oaks. We rested and dreamed - the flicker from the camp-fire, the Indians moving to and fro, the silence occasionally broken by their low, soft voices, and ever and anon in this wakeful slumber came the half-dreaming thought, 'Betty and me killed the bear!'"

\section{CHIEF TOM TIGER (MIC-CO TUSTENUGGEE).}

It is a number of years now, that Tom Tiger, chieftain, reached Kissimmee after a ride of 160 miles. Tall, straight and muscular, he proved himself a worthy descendant of the royal Tustenuggee. Dressed in the regalia of a chief, and mounted on a raw boned horse, he might have been mistaken for a sheik of the Arabian desert. He had come on a friendly visit incidentally, but to tell his white friend his trouble over a horse which had been procured under a fraudulent pretense, by a white trader. The story is a long one, but suffice to say proceedings were instituted and with the result that Captain Tom Tiger, Seminole chieftain, was the first Florida Indian that ever stood up in a white man's court, making, as the spectators remarked, the most imposing picture they had ever witnessed.

The tall, magnificent looking savage, with uplifted hand, took the oath on the holy Book, with a perfect understanding of its meaning.

The case was prosecuted by the Society, "Friends of the Florida Seminoles," and achieved notority for being the first case in Florida in which a Seminole 


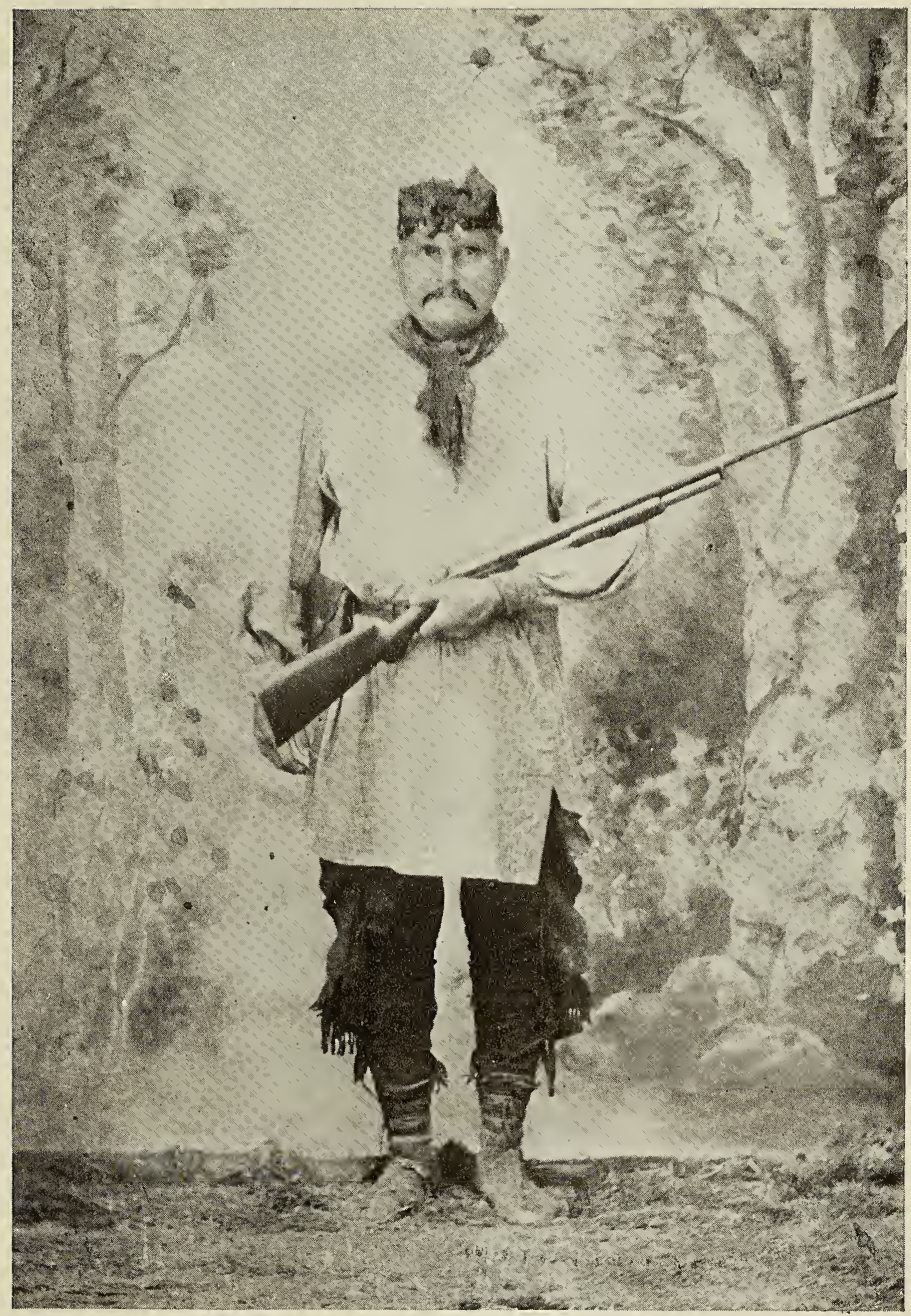

CAPT TOM TIGER

(Micco Tustenug-gee.) 

sought the protection of the court. It was told that the State's Attorney made the most thrilling speech of his life as he pleaded for the barbarian of the swamp. The Indian never swerved under the strongest cross-examination, but told the story simply and direct. The status of the case was this: The white man was to return the horse at the end of two moons, binding the promise by writing. The argument was written on a cartridge box; a terrific rain storm came; the box was soaked in water, and the writing made illegible. Because Tom could not read, he could not make oath as to what was written on the box, the white man testifying he had bought the horse. On this simple technicality the case was lost and the white man escaped the penitentiary.

Like many of his race, Tom had a love for Wyo-mee (whiskey), and was not averse to taking it. In speaking of a saloonkeeper he would say, "Captain, good man, five Indians go in saloon, five drinks give 'im. No money take," but when Tom was asked to drink no whiskey in Kissimmee, he promised, "un-gah" (all right). A day or two after, the white friend stepped out of his office, and looking back saw the tall form of Tom just passing into the saloon - headed by three cowboys. Tom returned to the office, and his friend chided him for going to the saloon. "Whiskey, me no take 'em, lemonade, me take, cowboys wy-o-mee take." The white friend's trust had not been betrayed.

In this Indian's visit of a week, many chapters were revealed of the character and home life of this 


\section{I50 THE SEMINOLES OF FLORIDA}

tribe. Savages, it is true, but honor, justice and religion shine forth in their tribal life.

During his absence, the squaws and pickaninnies watched the potato and corn patch, and cared for the hogs, surely worthy tribute to a domestic life.

In relating a tragedy of the forest, Capt. Tom seemed much affected. The chief, attracted by the cries of young birds, found that a rookery of the beautiful white heron had been completely destroyed by plume hunters, and the grounds strewn with the mutilated bodies of the parent birds. From the tall trees overhead the starving nestlings were spending their waning strength in calling for food. The pitiful scene touched the heart of the strong red man, and he paused in his journey to find food for the helpless birdlings. In relating the circumstance, the Indian said, "Little birds, cry, cry, all day. No water, no fish," till the Indian boys caught minnows and daily climbed the lofty trees and fed and watered the young egrets, a tribute to the savage mind over the cruelty of the civilized and Christianized white man.

A few years ago, Florida was an ornithological Eden, the winter home of countless thousands of the migratory birds of the North American Continent; but alas, the blood thirsty greed of the Caucasian for gold is shown in the brutal extermination of the plumed egret, and "the passing of the snowy heron" is the price of human callousness. The Indian chief probably did not see in the fate of the innocent plume bird, a prophecy of the destiny of the Seminole.

The same forces are at work to-day to take from 


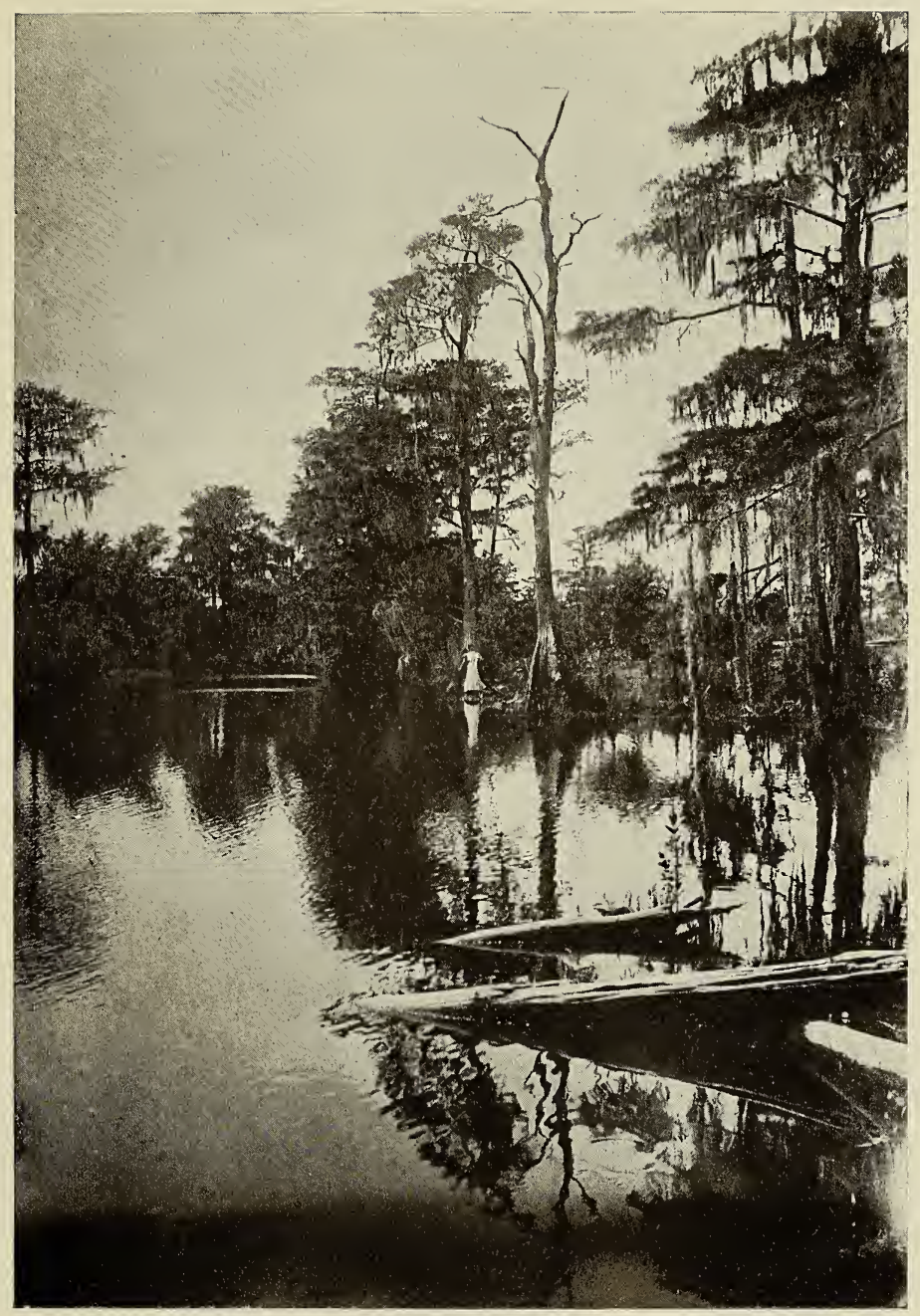

THE INDIAN'S IIUNTING GROUND

"Within a mile of the wigwams, the big dredges clank and groan, an accompaniment as it were, to the dirge of the recessional Seminoles." 



\section{THE SEMINOLES OF FLORIDA I5I}

the helpless Seminole his home and happy hunting ground.

Tom Tiger made his last visit to Kissimmee during the Spanish-American war, and a touching and pleasing feature of the visit was the meeting between General Fitzhugh Lee and this Chieftain of the Seminoles.

The train bearing General Lee and staff stopped at Kissimmee, where crowds of citizens went to welcome the hero of the Southland. General Lee, dressed in his rank as U. S. general, Chief Tom Tiger in the regalia of a Seminole chieftain. The scene is indelibly impressed upon all who witnessed the meeting. The Indian chief with the Stars and Stripes in his hand, was introduced and shook hands with the great American soldier. In hearty tones General Lee responded, "I am glad to see you, Chief."

Tom was told he must "yell" when the train came in. He understood and answered, "Me holler (ojus)," and he did, a genuine Seminole war cry, "Yo-he-ee-hee - Yo-ho-ee-hee!"

Driven and hunted, homeless and helpless, this Indian was a strong ally of the United States. "No fight white man," meaning the people of the United States, "shoot Spaniards, ojus" (heap), was Tom's reply when the attitude of the two countries was explained to him.

One by one the older Indians are passing away, and when word was received that Captain Tom Tiger had been killed by a stroke of lightning, the news 


\section{I52 THE SEMINOLES OF FLORIDA}

was received with genuine sorrow. In his death, a fair, generous and faithful friend was gone. Captain Tom was building himself a dugout canoe on the edge of the cypress swamp, his family being with him at the time. Seeing an approaching storm, he sent them back to their wigwam. When he did not return, the Indians went to seek him and found his dead body. Other Indians turned the unfinished canoe into a mausoleum, and there rested his remains until an avaricious curio seeker sought it out and robbed it of the body of the chief. Considering the tender respect the Florida Indians have for their dead, and also the superstition that any desecrations of the bones bring dire calamities to the tribe, it is not surprising that this act of vandalism aroused the Seminoles to the highest pitch, and they were stirred as they have not been since the days of the Indian wars. The whites realized that unless they were pacified they were liable to give trouble.

Two of the leaders of the band visited the authorities at Fort Pierce, Florida, and the newspapers of that date give the following account, "Big Yankee steal bones of Tiger Tom, Indians Big Chief and best friend. Indians all fight. Kill white man ojus, bones no bring back by big white chiefs next moon."

The matter was immediately taken up, and information filed by the State Attorney in the Circuit Court against the party, charging him with disturbing the grave of another and having in his possession a dead body. All over the United States the account 
was taken up by the press and looked upon as a matter of serious importance, as the Smithsonian Institution was credited with being behind the rapacious curio hunter.

The matter was brought to Mr. J. M. Willson, Jr., recognized as the Seminoles' best friend among the whites.

The letter following explains the situation and is herein given:

\section{SECRETARY RATHBUN'S STATEMENT.}

- "Mr. J. M. Willson, Jr., Secretary Society of Friends of Seminole Indians, Kissimmee, Fla.

"Dear Sir:-Replying to your letter of the 24th inst., I beg to say that about six weeks ago a Mr. — about whom nothing is known here, wrote to the National Museum and - offered to present certain Indian relics which he had obtained in Florida, including a skeleton of an Okeechobee (not Seminole) chief. Assuming that these objects were properly acquired by him, he was notified that they would be accepted. No further word or the objects arriving, it has, therefore, been supposed that he disposed of the relics elsewhere. The heading of his letter paper indicates that he is the secretary and general manager of an amusement resort, called Island Park, at - Pa., and it is not impossible that the relics were taken there.

"Although I find that the name of the chief was mentioned in Mr. —'s letter, the fact that he spoke of him as belonging to the extinct Okeechobee tribe entirely misled the Museum authorities who did not associate him with the Seminole Captain Tom Tiger, about whom so much 


\section{I54 THE SEMINOLES OF FLORIDA'}

has lately been printed in the papers until the receipt of your letter to-day.

"I cannot express too strongly my abhorrence of the act of Mr. - , whose desecration of this grave I consider outrageous and sacrilegious. The man had no connection with this museum or any branch of the Smithsonian Institute, as he seems to have claimed several weeks before he sent in his letter.

"You can readily understand, therefore, that the museum will be only too glad to coöperate with your society in securing the return of the remains and of any objects that may have been taken with them from the grave. If they should be received at the museum they will be promptly forwarded to Florida.

"I have forwarded your letter to $\mathrm{Mr}$. —, at the address given in his letter, viz: $\operatorname{Box} 53 \mathrm{I}, \longrightarrow, \mathrm{Pa}$, , and $\mathrm{I}$ have also written him.

"Trusting that this unfortunate matter may soon be satisfactorily adjusted, I am, dear, sir, very respectfully yours,

"RATHBUN,

"Assistant Secretary in charge of National Museum."

The bones of the noted Indian were quietly restored, and all trouble averted, but of the throbbing hearts of these interesting countrymen of Osceola what shall we say?

\section{NANCY OSCEOLA.}

A short time ago, the press chronicled the news that the old Seminole squaw, Nancy, living at the Big Cypress camp, was dead. The account stated 


\section{THE SEMINOLES OF FLORIDA $\quad$ I55}

that Nancy was the widow of the famous chieftain (Osceola), and that she was survived by seven children. The associated press took up the story and many accepted it as true.

It is the desire of the writer to say that Osceola's wives (for he had two) went into captivity and were with him when he died, a captive of the United States Government, and is is safe to suppose they, with his children, were taken with the other Seminole captives to the West.

Oid Nancy was the squaw of a half-brother of Osceola - hence a sister-in-law. A few years ago she consented to have her picture taken amidst a group of her great-great granchildren. Chief Tallahassee quickly recognized the picture and said, "Old too much - eyes no see, blind ojus." When questioned as to her identity, with the suggestion that she might be Osceola's widow, Tallahassee showed marked disdain, "No, no, Osceola, big chief. Squaw no got one in Florida. Old Nancy Osceola's brother's squaw."

\section{BILLY BOWLEGS '(CHO-FEE-HAT-CHO).}

Several months ago, Cho-fee-hat-cho (Billy Bowlegs), a warrior of more than usual intelligence, made his long-promised visit to Kissimmee.

Here, away from his natural surroundings, one could study his Indian characteristics from an unprejudicial standpoint.

As a speciman of manhood, he is far above the 


\section{I56 THE SEMINOLES OF FLORIDA}

average. Although six feet, two inches tall, he is so symmetrically proportioned that one loses sight of his height. His features are good, his hands and feet remarkably small, his voice soft and low - a characteristic of every Seminole.

His dress was the holiday attire of the tribe, his tunic or shirt he had made himself, was highly decorated with bands of narrow red,-- leggins and moccasins elaborately thonged, and around his neck about a dozen gaily colored handkerchiefs, not worn for warmth, but because it is a Seminole fashion.

His large turban was embraced by a silver band, made from four silver dollars beaten with the implements which can be found at an Indian village. He wore a gold watch and chain and regulated his timepiece by the railroad clock. Billy is a fantastic dresser, but he is a loyal Seminole and a progressive one, too. He keeps posted on the markets in his own particular line of business. His pockets bulge with letters received from New York and Jacksonville buyers of skins and otter pelts. He expects no favors, pays for what he receives and keeps a promise, although a year may elapse before he is able to do so. He is often a purchasing agent for members of the band, and in his small way has a mercantile mind, buying four shawls for $\$ 1.75$ that would retail at fifty cents each, he will sell out, with the satisfactory remark, " 25 cents me make 'em."

Billy ventures beyond the confines of his Everglade home, much oftener than any other of the tribe. To the stranger he is all indifference, answer- 


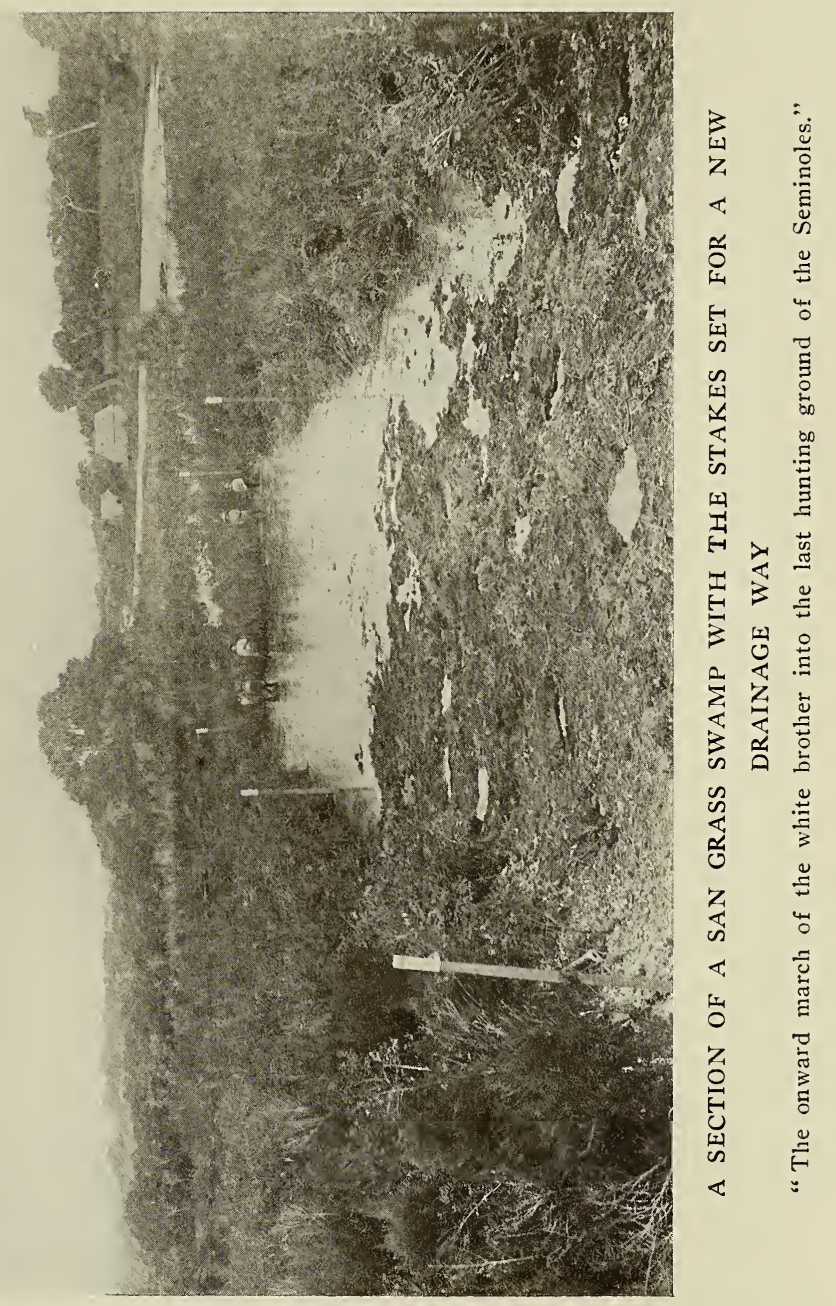





\section{THE SEMINOLES OF FLORIDA 157.}

ing: "Yes," "No," "Me don't know," as it suits him.

Billy has visited St. Augustine, and has seen the Ponce De Leon Hotel, but explained that "no get inside." The season was not "on," otherwise the Seminole brave would have been one of the celebrities that enter its great portals. New York and Washington do honor to dukes and counts, and this Aboriginal American Knight is no less a Prince of the Everglades.

He has made several visits to Kissimmee, hence is well known to the white people. At the ringing of the church bells on Sunday morning it was explained to the Indian that they were to call the people to the church, so that the preacher might tell them of the white man's God. With the inquiry, "You go?" to his host, and receiving an answer in the affirmative, Billy said, "Me go too."

He was escorted to the chapel and through the long sermon was a model of propriety and conformed perfectly with the customs of the church. He expressed himself later as liking the music, but remarked that the "preacher talked too fast."

From time to time colored pictures from Sunday School charts have been given or mailed to the Indians and Billy reports, "Indians got 'em," keeping them with their treasures in boxes or trunks.

Blue backed spelling books had been sent to these Indians, for the spelling book is the Seminole's ideal in literature, and Billy reported that the books were in good order - and Indian boys, spell "littly bit." 


\section{58 THE SEMINOLES OF FLORIDA}

Who shall say there is no hope for the civilization of this picturesque tribe?

Not a hair's breadth will this Indian diverge from the truth. Even to the simple question as to when he would visit his white friends again, he replied, "Six moons; me don't know, maybe ten moons; six moons, me say - no come, white man say, 'Billy Bowlegs lock-a-dox ojus!' (lie too much)."

Billy is grateful for favors shown him and on his return from a visit always sends some remem-! brance. A letter usually accompanies the present, and the following is a unique specimen of his literary ability:

"Indian Town, Fla., J. M. Willson, Jr., Kissimmee.

I write you Letter. I send you Big Alligator Feet skin. Big Alligator I $2 \mathrm{ft}$. long $4 \frac{1}{2}$ inches. This time Indian no sick All Good Well Ojus. You write to me Letter. Your Friend

$$
\text { Mr. Billy Bowlegs." }
$$

In his signature, Billy always uses the prefix, "Mr."

At another time on Billy's return to his Okeechobee home, a letter was received which read:

"MY Good FrIEND:

"Littly white birds me send. Indians all well." 
The egrets, snowy white and beautiful as a poem, came in a crate made of green palm stems, with a door fastened by buck skin hinges and buck skin catch, the whole a marvel of neatness and ingenuity.

The birds were at once given the freedom of the lawn, where they have been a constant surprise, in showing how full of confidence, how charming the wild heron can be made under habits of domestication. They love companionship and at meal time they station themselves like two sentinels, at the dining room piazza. Here they stand, with their long necks craning into the door-way, alert and tense, waiting for their beef to be thrown to them.

These white plumed egrets, with their dark, piercing eyes, their spotless white figures adorned in their bridal veil of long silken plumes, make a picture that an artist may envy.

It is a pleasing and encouraging fact that on all occasions when the Seminoles visit white settlements they are warmly welcomed by the whites and treated with the utmost respect and many times entertained as one would celebrities.

The Florida-Times-Union always breaks a lance in favor of the Seminole. During a carnival season in Jacksonville, Billy Bowlegs visited the city, and of his visit an editorial read:

"Jacksonville has among her guests this week one of the most representative Indians in America to-day - the highest type of what is known as the savage tribe. . . Billy was a conspicuous figure in last night's parade; he rode in 


\section{I60 THE SEMINOLES OF FLORIDA}

one of the most striking and effective floats of the parade, that of the Florida East Coast R. R. Company. . . . This float bore the distinction of conveying the noble figure of this Seminole chief and thus the only one with a member of the real and single strictly American race. Billy Bowlegs is no savage, but a magnificent specimen of physical manhood, with a dignity, a reserve, a keen intelligence and an honest heart - a representative of that forlorn remnant who regard honor with commendable sacredness."

Billy visited the Times-Union office, and took the keenest interest in the mechanical equipments for making a newspaper.

A fac-simile of Billy's writing appeared in the paper at this time and, a year later, it made an amusing picture to witness Billy's expression when he was shown the fac-simile; the clipping having been taken from the paper at the time. Very quickly memory came to him and he said, "Me know; my name write big paper, Jacksonville."

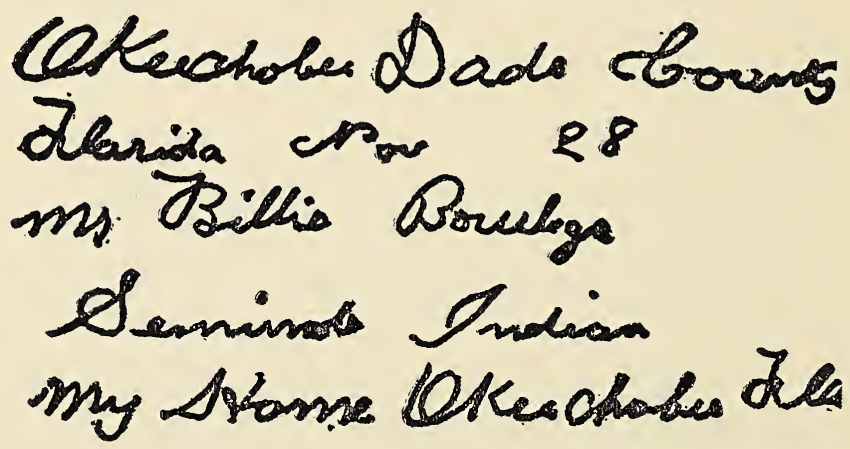

Such names as Tom Tiger, Doctor Tommy, Wild Cat and Billy, Bowlegs, are white man's names for 


\section{THE SEMINOLES OF FLORIDA I6I}

the Indians. Each Indian has his Indian name, which is significant of some family or personal characteristic, and which contains the root word of the gens to which the Indian belongs. During the Indian's visit he expressed a wish to have the Seminole names of a number of his people written down so that he might make a copy and carry home with him. Certainly this young brave could not be called stupid or sluggish. Knowing that the information was sought for the purpose of putting it into a book, so that "the people could read about the good Indians of Florida," he showed the greatest interest in the questions, making his answers direct and truthful.

With the patience of a sphinx this Indian answered questions till dark. When asked if he were tired, he answered, "Tired ojus," although his native politeness had not permitted him to show any special restlessness at the tedious afternoon's questioning. An air of deepest solemnity would rest upon his face until he was assured his meaning was thoroughly understood. During his visit he expressed an eagerness to learn, and followed a copy with remarkable exactness. With the desire to read and write, however, ended all ambition to be like the white man.

Every effort was made to please so rare a visitor, favors were shown him, in fact he was treated as a most honored guest, yet this son of the forest received it all with a silent dignity that would have graced a monarch. When he was ready to leave he 


\section{I62 THE SEMINOLES OF FLORIDA}

quietly arose, remarking, "Me hi-e-pus" (go), and noisclessly passed out of the house.

It is a disputed question whether a wild Indian of pure blood has ever been permanently civilized. One of the missionaries of the Osage band once said that "it took fifteen years to get a blanket off Joseph Pawnee-o-passhee, Chief of the Osage tribe, and it took Joseph just fifteen minutes to get it on him again."

\section{RELIGION.}

A pretty tradition among the Seminoles is that a beautiful race of Indians, whose women they call the daughters of the sun, reside among the swamps and lakes of the O-kee-fee-ne-kee wilderness and live in uninterrupted felicity upon islands of eternal verdure, feasting upon the luxuries of the islands, but inaccessible to the approach of human footsteps.

Unlike the child of Africa, who lives in a world of ghosts and goblins, the Seminole is not superstitious. He has his traditions, his mythologies, and on these are based his history. He obeys the Great Spirit, but it is not from any spirit of fear; it is the teaching of his fathers, and becomes the duty of the Indian. The religion of the Seminole has been without question the most difficult of all their history to reach.

The Florida Indians believe in a Supreme Being; in the immortality of the soul; in the future existence 
and the resurrection of the dead. Reverence, too, is one of his distinguishing features. His language contains no oath, nor any word to express disrespect to the Great Spirit. A missionary will receive most respectful attention for their reverence to God will not permit them to laugh at $\mathrm{His}$ messenger. The Seminole qualifies the Supreme Being as the "Giver and Taker away of Life." The Aztec designated, as the "God by Whom We Live."

Their conception of the creation of man is very unique. "Long time ago, E-shock-e-tom-isee (God) took seeds and scattered them all around in a rich valley bordering a river. By and by, God saw fingers coming out of the ground and great people - heap too many came up from out of the sand. Some went to the river and washed, washed, washed too much; it made them weak and pale; this was the es-ta-chat-tee (white race). Others went to the river and washed not too much, they returned full of courage, strong, heap; this was the es-ta-hadkee (red race). The remainder no wash, lazy too much, es-ta-lus-tee (black man)."

In an extract taken from an old history printed in London in 1776 , descriptive of the native inhabitants of Florida, these people are described as idolaters, worshipping the sun and moon - the worship consisting of saluting the rising sun, chanting his praise and offering sacrifices to the planet four times a year. They believe that the sun was the parent of life. 


\section{I64 THE SEMINOLES OF FLORIDA}

Whatever may have been the ancient rites of this race, the present people seem to have outlived all remembrance of them as well as of their early ancestors themselves. A glimmering of the Christian religion, no doubt instilled into the race more than two hundred years ago by the Franciscan priests, still seems to linger among the descendants of to-day and constitutes their religion largely. These rites they observe as faithfully as they did a century ago; and yet in all that time they have received no further teaching, and have no personal knowledge of the civilizing effects of the gospel of Christ. In the same length of time where would have been the religion of the Caucasian race, without the divine word, and without the influence of men who have devoted their lives to the cause of Christianity? The Seminoles believe in God (E-shock-e-tom-issee); that God had a son (E-shock-e-tom-issee-e-po-chee) who came on earth and lived with the Indians "long time ago to make them good Indians."

One is tempted upon an intimate knowledge of this race to wonder whether the Son of Man appeared to the Indain also; could not the Light of the World in some mysterious way have touched the soul of this innocent people? The more one studies the Seminole, the more one wonders. Christ, according to their traditions, was killed by the "wicked Spaniards" when they first came to this continent. Since that time it has been the duty of the medicine men to teach the Indians "to think with God," and to impart the Great Spirit's wishes to his red children. Each tribe 


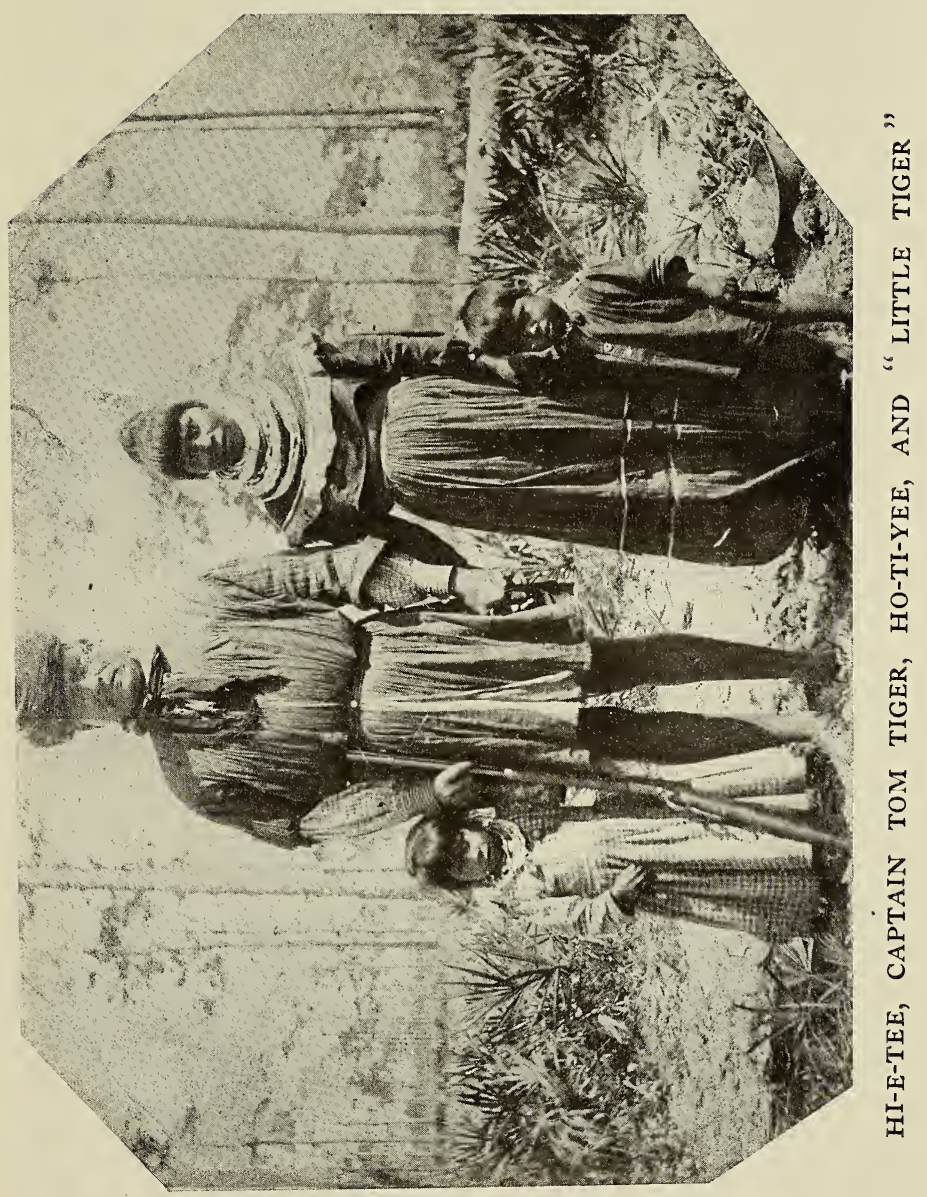



has two or more medicine men who act as priests as well as doctors. These men are highly honored by the tribe, because they believe them to be directed by the Supreme Being. Just before the festival of the Green Corn Dance the medicine men leave the tribe, and going to a secret spot, there build a lodge. Here they fast for twenty-four hours, after which they take a potion, made of herbs, which causes a deep sleep to come over them. It is now that God appears to them in a dream and tells them how to make the Indians "think good," and how they shall prepare the herbs for medicine. Returning in time to prepare for the great feast they occupy a most prominent position in the dance circle. The Seminole tradition of Christ's coming to live with the Indians, is that the Son of God stopped at the most southern point of Florida, at which place he was met by three Indians who carried him around the Southern Peninsula on their shoulders, while he sowed the seeds of the "koonti" root, which was God's gift to the red men. (This koonti is a wild cassava and found only in the extreme southern portion of Florida.) According to the legend, the Indians were in a starving condition. The ground was parched, no corn grew and the game had all left. During the long time in which the Indians waited for the koonti to grow, God rained down bread "heap, plenty," which the Indians gathered and ate. In describing this bread, which came down in the rain each morning, the Indian illustrated in this wise: "Littly bread, white man's biscuit all the same, good, every Indian eat 


\section{I66 THE SEMINOLES OF FLORIDA}

plenty." The Mosaic account of the manna from heaven is evident in this legend.

The Seminole believes in a future state, In-liKe-ta (heaven or home). To this place do the good Indians go after death. Here they may " hunt, hunt, hunt, plenty deer, plenty turkey, plenty bear find, and cool water ojus (plenty) all the time. Bad Indians after big sleep hunt, hunt, hunt, hunt deer, turkey, bear - no find 'em, hot water drink all the time."

The Indians' religion, for we may justly call it so, is sacred to him, and it is difficult to get him to reveal his inmost thoughts. His idea of the Bible is vague, because he understands it as the work of man. "White man got book, him good one day, he steal, cheat next day; book no good. Injun no make book, he no see hunting ground, him no go and come back. Big sleep, no come back, him no lie about it. Me think good Injun find hunting ground all right; me think me find it. White man, big sleep comes, me think no find In-li-Ke-ta (heaven) easy."

After death the body of a Seminole is immediately prepared for burial, the corpse being clad in new clothes. When a chief dies one cheek is painted red, the other one is painted black. The rest of the tribe do not have the face painted for burial. It will be recalled that Osceola, with the death struggle already upon him, rose in his bed, and "with his own hand painted one-half of his face, his neck and his throat, his wrists, the back of his hands and the handle of his 
knife red, with vermillion," the marks of a war chief.

At sunrise, on the day following a death, the body is carried by two Indian men to the place of interment. The corpse is placed on a base made of logs with the face to the rising sun. If the deceased be a warrior, his rifle and accoutrements are placed by his side, "that he may be fully armed on his arrival at the happy hunting grounds." A bottle of Sof-ka is buried with him that he may eat on his long journey. Around the body is built a pen of logs sloping till they close at the top and thickly covered with palmetto leaves. The protection is to prevent the wild beasts from despoiling. With faces now turned reverently to the rising sun, they commend into the keeping of the Great Spirit the bivouac of the dead. The bearers of the dead then make a fire at each end of the grave, and the mourners return to camp, the women loudly wailing and tearing their hair. At the death of a husband the widow must live with disheveled hair for one year. Her long black tresses are worn over her face and shoulders, and she presents a forsaken, pitable appearance. At the end of twelve moons her period of mourning is over, and she may again arrange her hair, don her beads, which have been removed during her period of mourning, and may marry again. The husband, on the death of his squaw, may not hunt for four days, and for a period of four moons must appear in mourning, which consists in the removal of his neck handker- 


\section{I68 THE SEMINOLES OF FLORIDA}

chiefs, and the laying aside of his turban. When a death occurs in one band or settlement, the news is not communicated to the other bands until such time as it is convenient for a messenger to be sent.

\section{BROUGHT BACK.}

About fifteen years ago, one young Indian brave, Ko-nip-hat-cho by name, stepped beyond the Seminole law and asked permission to live with a white man at Fort Myers, Florida. He was eagerly received by the gentleman, and was taught much of the English language and civilized mode of living. But for a Seminole to so far forget the teachings of his fathers, as to wish to affliate with the white race, caused the greatest dissatisfaction in the Indian camps. "Talk after talk" was "made" by the chiefs as they met in council concerning the actions of this bold young Indian. He was repeatedly warned to return to the tribe. They even threatened to kill him if he refused to do so. At length, however, artifice succeeded, where all else had failed. The daughter of Charles Osceola was promised to him for a wife if he would but return to his people and once more don the costume of his race. No Indian girl in all the nation could boast of the beauty of Nan-ces-o-wee; damask and dark, with features as refined as the Caucasian, a form superb in its symmetry, a step as graceful as the doe's, a spirit as fearless as the falcon, such is the woman who moved Ko-nip-hatcho from his foreign alliance. Ko-nip-hat-cho has 


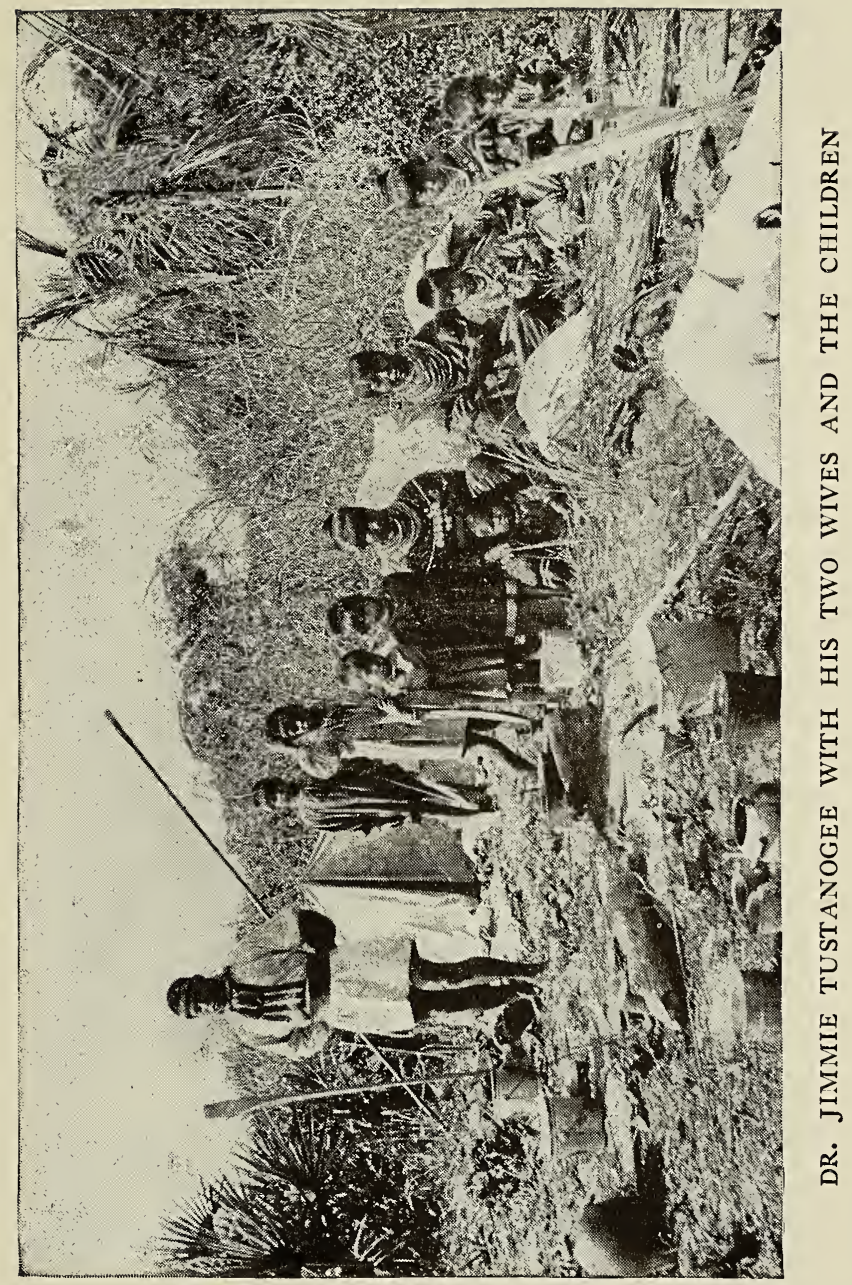





\section{THE SEMINOLES OF FLORIDA 169}

four children, is contented and happy in his forest home, and with his knowledge is an important personage among his tribe. His wife is the belle of the Seminole nation. All the Indian braves say, "Konip-hat-cho's squaw heap purty," and in their native tongue declare, "Nan-ces-o-wee most beautiful of all the Seminole squaws."

\section{MOUNDS.}

The great number of mounds found in Florida afford attractive study to the lover of scientific research. These mounds are of many shapes, heights and areas. They are found in all parts of the State, but are more abundant on or near the coast and along the water courses. Every few months some explorer, armed with shovels, picks and other instruments used in excavating mounds; comes before the public and announces new discoveries, based on new theories. The best possible explanation of the source of these mounds is founded on the theory that they are of Indian origin. One scientist has aimed a happy stroke at writers of our antiquities when he says, "Whoever has time and patience and will use his spade and his eyes together, and restrain his imagination from running riot among mounds, fortifications, etc., etc., will find very little more than the indications of rude savages, the ancestors of the present race." No better theories can be advanced than those of Major Powell, who says, "Remove the Indian element from the problem and we are left 
without a hypothesis." One of the latest mound excavations in Florida was made by Dr. Moore. A thousand skeletons were unearthed as well as many articles of pottery, and other things considered of great value by the explorer. The height and character of the Florida mounds indicate the different uses for which they were built. These mounds vary from three feet to thirty feet in height, and their areas range from a few square feet to four hundred feet square. The shell mounds which are numerous throughout the peninsula seem to have grown without any idea of purpose by the builders, and are merely accumulations of shells and soil. Year after year it was the custom of the tribes to congregate at certain localities for their festivals, and, living on shell fish, the shells in course of time formed vast mounds or elevations. There are a number of small mounds on the outskirts of Kissimmee City. Excavations have been made, and pieces of skeletons, beads, pottery and gold trinkets were exhumed. Other mounds in Florida indicate that they were built for tombs, while others, being composed of strata of sand and other soils, from their height might have been built for outlooks or signal towers. Chroniclers of De Soto's day describe the manner in which the natives brought the earth to these spots and formed these elevations. The Indians say in Seminole war days these mounds were used to build their signal fires upon. By smoke telegraphy, they communicated war news from one band to another. By this means, with their fleet Indian runners, who 
acted also as spies, the entire tribe was kept informed of the innermost workings of the white army. In asking a chief about the burial mounds, he answered, "Long time ago heap many people here," and that their " ancestors buried their dead in mounds so that other bands coming along might not disturb their bones." Many times the body would be carried a great distance in order to bury in a sepulchre where rested the bones of their ancestors. "Now," said the chief, "Seminoles no fight, not too many people;" and he buries his dead near his camp.

\section{PICTURE WRITING.}

The Seminoles have no picture writing, nor do their minds in any way run to art. They prefer the rough athletics of forest life, which educates them for the chase and makes them the vigorous and hardy people that they are. They would sooner "hook" an alligator than paint the finest picture the brush is capable of producing, and yet there is nothing in the white man's home they enjoy more than studying the pictures of a book. In this way they may be taught much. Through the teaching by pictures they have learned the story of Pocahontas, and of William Penn, "the red man's brother." On an occasion the picture of a heathen Zuni god was shown to an Indian and its meaning explained. The effect produced would have done credit to a Christian believer. 


\section{I72 THE SEMINOLES OF FLORIDA}

\section{MEDICINE.}

The Seminoles have a superstitious faith in the efficacy of certain roots and herbs known to their tribe, the knowledge of which has been handed down from their remote ancestors. The curative property of these plants they never question. 'A few of the band to-day have carefully concealed about them small pieces of a root, which they call " hil-lis-waw." This root was gotten by some of their tribe sixty years ago when their people were encamped at Tampa, and has been carefully treasured ever since, having been handed down from father to son. Their faith in the healing powers of this root is marvelous, their idea being that the smallest possible piece being made into a tea would restore life from death almost. Those fortunate enough to own a small piece the size of a pea are considered to have a great treasure. On testing this root it was found to be a simple plant, the great medicinal qualities of which exist largely in the minds of the Indians. They are ignorant as to what the root is and believe it to be very valuable, saying, "So much (what one could hold in the palm of his hand) cost \$25." "Long time ago," says the Seminole, "chief sick heap too much; byand-by, big sleep come. Medicine man bring hil-liswaw, fix 'um quick. Chief get well."

A late incident occurred, showing the childlike faith of this people. The little son of Ko-nip-patcho was taken very ill and when Seminole medicinal efforts failed, the father learned from other Indians 


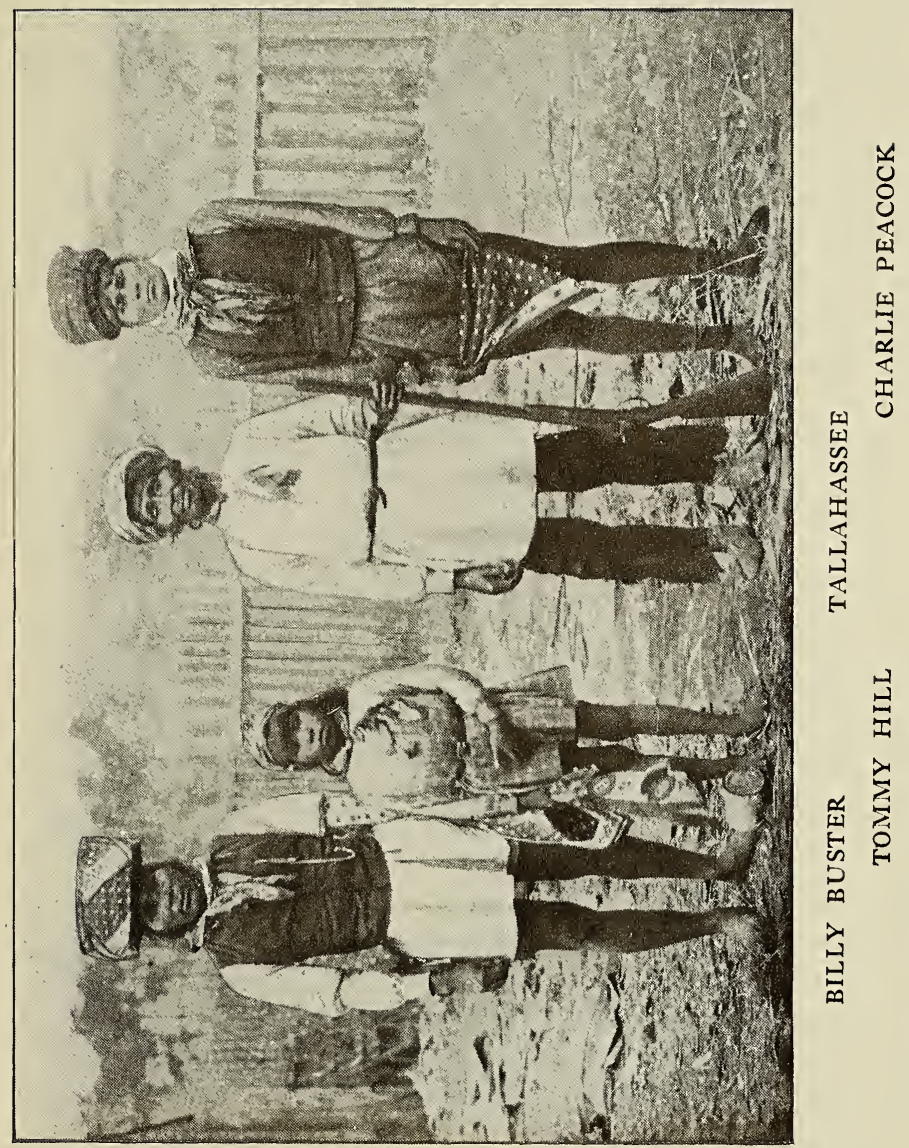





\section{THE SEMINOLES OF FLORIDA 173}

that their white friend at Kissimmee City could procure for them the "hil-lis-waw." A runner was dispatched from the Everglades to the nearest boat landing (a distance of 160 miles from Kissimmee) where a note could be sent in person. This note was given to the Captain - the Indian waiting for the return of the steamer. The Indians reported afterwards, "Boy sick ojus, arms cold - feet cold - big sleep come soon - Indian bring medicine from white friend, boy no die."

Did not the Great Spirit, Who watches over His children, reward the childlike faith of these Indians?

Pais-haw is the name applied to a plant which the Indians regard as an antidote to the rattlesnake bite. Old settlers tell that they have known of Indians allowing themselves to be bitten by a rattler on a wager of a silver dollar. The Indians after being bitten would go to the woods, a short distance away, and procure their antidote. Returning they would apparently be no worse for the bite. Requesting an Indian to procure some of the roots, he replied, "No find 'em here - by-and-by me go to Okeechobee swamps, find 'em plenty."

A few weeks later there came through the mail a small box full of roots, neatly done up and addressed by the Indian's own hand, a perfect copy of name and address as he had learned to write it during his visit.

On sending the roots to the Smithsonian Institute for analysis, the secretary reports that they belong to a species of plant known as Cyperus, and adds, "This 


\section{I74 THE SEMINOLES OF FLORIDA}

is one of the large number of reputed cures for snakebites, which have become so regarded from the fact that a person who has been bitten has been known to recover after taking the drug." The use of water enters largely into the materia medica of the Seminoles, bathing in cold water being one of their principal treatments for fevers. During the war with the whites a soldiers' camp was found deserted; the Indians immediately appropriated the clothing, blankets and other things. Very soon the loathsome disease of small-pox broke out among them. Ignorant as to the nature of the malady, they immediately applied their bathing remedy. The result was a frightful mortality, few of that band were left to tell the story. In this instance, the Government army gained a victory over their foe without the firing of a gun.

FLORIDA'S ABIDING WORDS OF BEAUTY THE HERITAGE OF THE ABORIGINAL PATHFINDERS.

All through Florida the musical softness, peculiar to the Seminole dialect, is sustained in the names of the lakes and rivers. Each having a history descriptive of its character, or some incident connected therewith.

The old names of the chiefs were very euphonious, such as Osceola, Micanopy, Tusteenuggee, Coacoochee and Tallahassee. These are being displaced by names adopted by the whites, such as Billy Ham, Tommy John and Billy Buster. Accident, too, seems to have credited the aborigines with words not really 
their own if it be true that "Yankee" is only an attempt made by the Indian to speak the word English, and that pappoose is the effort of the natives to say "baby." The symphonious cadence of such words as Alabama, Tuscaloosa, Caloosahatchee and Minnehaha has often been noticed.

Tohope Ke-liga is the name of one of the most beautiful lakes in Florida, its Indian significance meaning "fort site." All around the lake are the old hunting grounds of the Indians and memorable points in Seminole war fame. To-day the Okeechobee drainage canal connects it with the lakes south, plantations surrounding its shores; the thriving city of Kissimmee is situated on its north side and all trace of the Seminole has vanished. The only memorials he has left are his words firmly embedded in the history of his conquerors. Kissimmee river is said to have taken its name from a romantic episode. A young Spanish grandee in a moment of impulse snatched a kiss from a Seminole girl, and the frightened maiden's childlike plaint to her mother established the name of the river on whose banks the kiss was stolen - Kiss-him-mee.

The romance attached to our beautiful Kissimmee river gives it especial interest and we give it only as a traditional meaning. The present Indians cannot give the English rendition, saying, "Indian long, long time ago named the river," which is corroborated by the Bureau of Ethnology, Smithsonian Institution, as follows: 


\section{I76 THE SEMINOLES OF. FLORIDA}

In reply to your letter I regret to say that it is impossible to give you the meaning of "Kissimmee." Several of our ethnologists think the word dates back to the Ais Caloosa, or some other tribe antedating the Seminoles, in which case the meaning will never be known.

Very respectfully yours,

W. H. Holmes,

Chief.

So many of the euphonious words abounding in Florida belong to the ancient tribes and were picked up by the Seminoles.

An interesting bit of information was gotten after much care and questioning from Chief Tallahassee as to the meaning of his name - Tallahassee being only a nickname, or white man's name for him his Indian name being Fo-so-wa-los-te-nock-ee, meaning chief of the Bird gens or tribe.

The origin of the name of Florida's State capital dates back to the days that are but traditions to the Seminole.

As the Seminole interprets, "Long, long time ago," many Indians and houses were on the site where the city of Tallahassee now stands.

One day, as the tradition goes, all the Indians left. Some time after, some Indians came along, Seminoles presumably, and seeing many houses - but Indians "hiepus" (gone), exclaimed, "Tallahassee "__ all gone or deserted."

We-la-ka is the Indian name for the St. John river and describes it so graphically that the old Spaniards retrograded when they named the "river of lakes" 


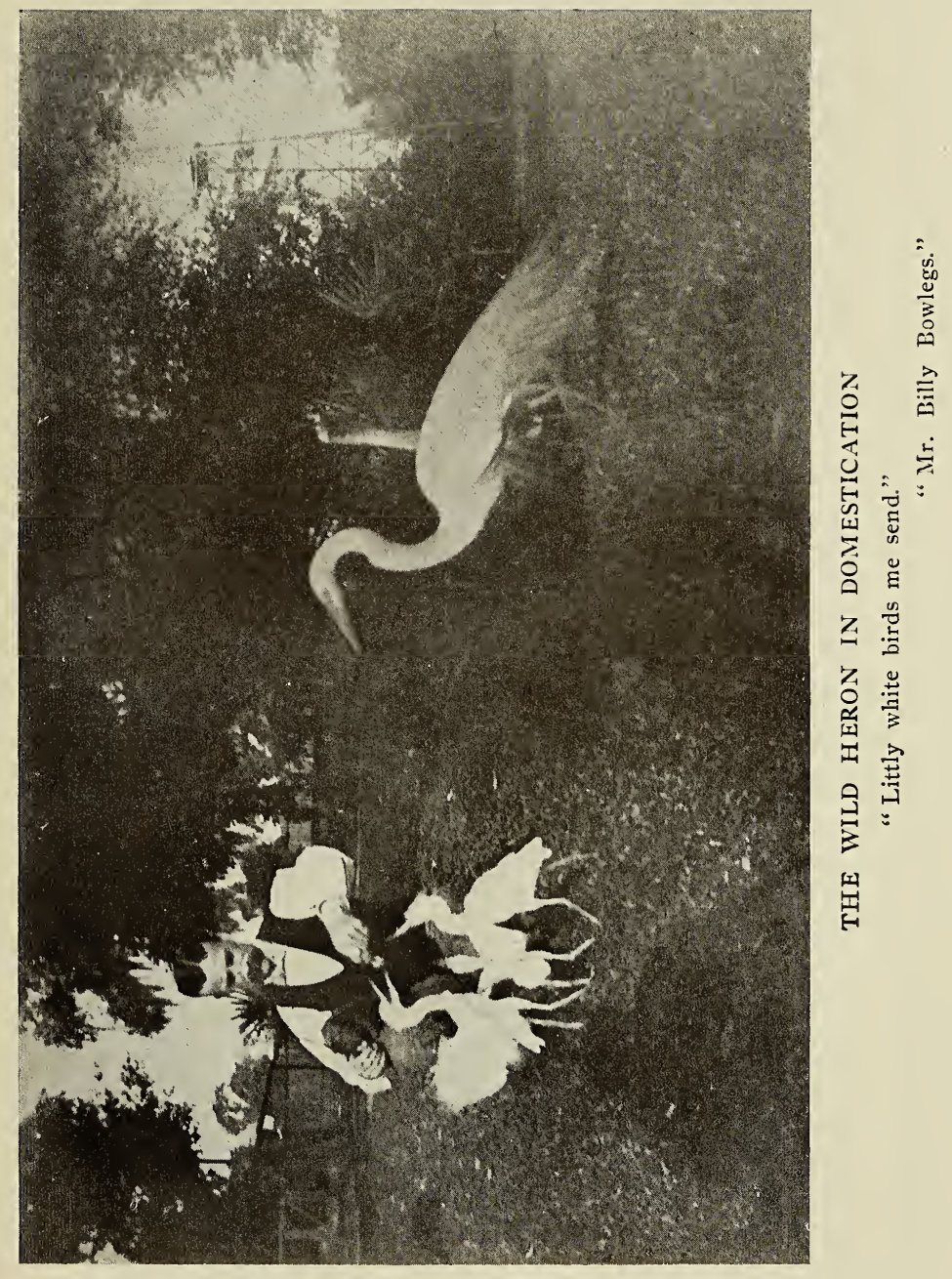



for their patron saint. Ock-la-wa-ha, " crooked water," appropriately describes the most crooked stream in America. Okeechobee, with her vast expanse of water and over-hanging mists, in Seminole significance means "the place of big water." Withla-coo-chee, so memorable in Seminole war days as the place of Osceola's strategic movements, is a long but very narrow stream, meaning, in the Seminole tongue, "Little Big river." Alachua, " the big jug without a bottom," We-Kiva, "mystery," and so on all over the Peninsula do we find names preserved which mark the wanderings of the picturesque Aborigines.

The unwritten, but highly poetical, language of the Florida Indians, should be incorporated into schoolcraft form and preserved with the archives of history for future generations. One who has heard the war shouts, their mythological tales, the words accompanying their dancing tunes, or listened in the darkness of the night, with breathless wonder to the heart-moving dirges sung by wailing women as they move around the corpse of some dead member, the whole scene lit up by the flickering flames of the lurid camp fire, cannot doubt but that the Florida Indian has a literature, and the white race is to blame for its imperfect knowledge of the unwritten but priceless productions of a savage race.

The linguistic perfection of the Seminole language, with its fluent, oratorical powers, shows itself in every speech or talk ever made to the white man.

With linguistic research, the scientist readily finds 


\section{I'j8 THE SEMINOLES OF FLORIDA}

that man does not invent language any more than a birds does its twittering or a tree its leaves. It requires a whole nation to produce a language.

Of the world's famous orators we have our Demosthenes of the Greek, Cicero of the Roman, England's great Gladstone, America with her Calhoun, Clay and Webster; but as yet has the world ever found greater eloquence than in the "talks" of the famous Indian chiefs?

Red Jacket, on the religion of the white man and the red race, is a marvel of eloquence. Then what shall we say of Tecumseh, the great Shawnee, as he delivered his famous talk to General Harrison, or Black Hawk, the captive, in his plea before General Street?

In dealing with the Seminole language we meet with long words and mammoth expressions. The Seminole greeting, "Ha-tee-eten-chee-hick-cha-hit-ischay," sounds formidable, yet it only means "Glad to see you." These, with well-understood Indian phrases, such as "burying the tomahawk," "going on the warpath," we employ familiarly without a thought of the tribe we have dispossessed. The time for studying the aborigines of America will soon be over. Only remnants of the tribes remain among us. Old myths and customs are being displaced by new ones, and we can truly see that the red man's inheritance is nearing the horizon of its destiny. 


\section{THE SEMINOLE'S RECESSIONAL.}

When the last Seminole goes, he will in every sense be the last. He will leave no history; neither monument. His narrow path through the Savannah lasts no longer than the doe's road to the ford of the stream. His race have had their joys, their triumphs and their defeats, and then been swept into oblivion.

Like the white plumed egret of the vast forests of the Everglades, he will pass, like the mist. As memories come up, we hear the faint rustle of the leaves and see the dusky forms of those ancient people as they glided through the leaf-carpeted aisles of the forests. We see the happy wigwam homes, gleaming in the red flames of the camp fire and hear the soft lullabies of the crooning mothers; the dusky hero of the chase returns game-laden from the hunt, and, in the picture, framed, as it were, by the boundaries of nature, we see long lines of moving life, the graceful forms of thousands of flying creatures, while the song of the forest minstrel hallows the wooded silence. It is the land of the Seminole.

Thou, Florida, with thy laughing waters and sunny skies, art the Seminole's elysium. Thy spreading palms form the only canopy he desires. To part from thy loved scenes would be like separating from his kindred. No, under the shadows of the live oak and the magnolia has he lived, under their shadows let him die.

As the patient Seminole, with swelling heart "moves a little farther, and yet a little farther," he 
goes not willingly, but with a sad heart and a slow step. Micanopy, when told by the officers that he might choose between emigration and death', answered, "Kill me here then, kill me quickly." The same spirit is manifested by the Seminole to-day when he says, "We have never done anything to disgrace the land of our birth, nor the honor of an Indian. For fifty years the pledge to our great father has been kept inviolate. Our tongues are not forked and our feet tread not in the white man's path. We threw away the rifle and grasped hands with the white skin. We know the white man's power, and though we love peace, we fear not death. We will not leave the land of our birth. The Great Spirit loves his red children, and says to them, "Your bones must rest with the dust of your fathers." Brothers, when the pale face came to the shores of our land, our fathers made him a fire from their flint rock to warm by, and gave him hominy to stay his hunger. Brothers, the Seminole wishes no harm to the white race, but his heart heaves and surges as it says, "Let us alone; let us alone. Though you slay us, you shall not move us."

"A kingdom as full of people as hives are of bees," wrote the first discoverer to King Ferdinand. Where are they now?

There is something intensely sad in the picture of these sons of the monarchs of that race, who, for centuries held sway on the slopes of the Atlantic. As the Stars and Stripes proudly herald liberty and independence to the comers of all nations, how can 


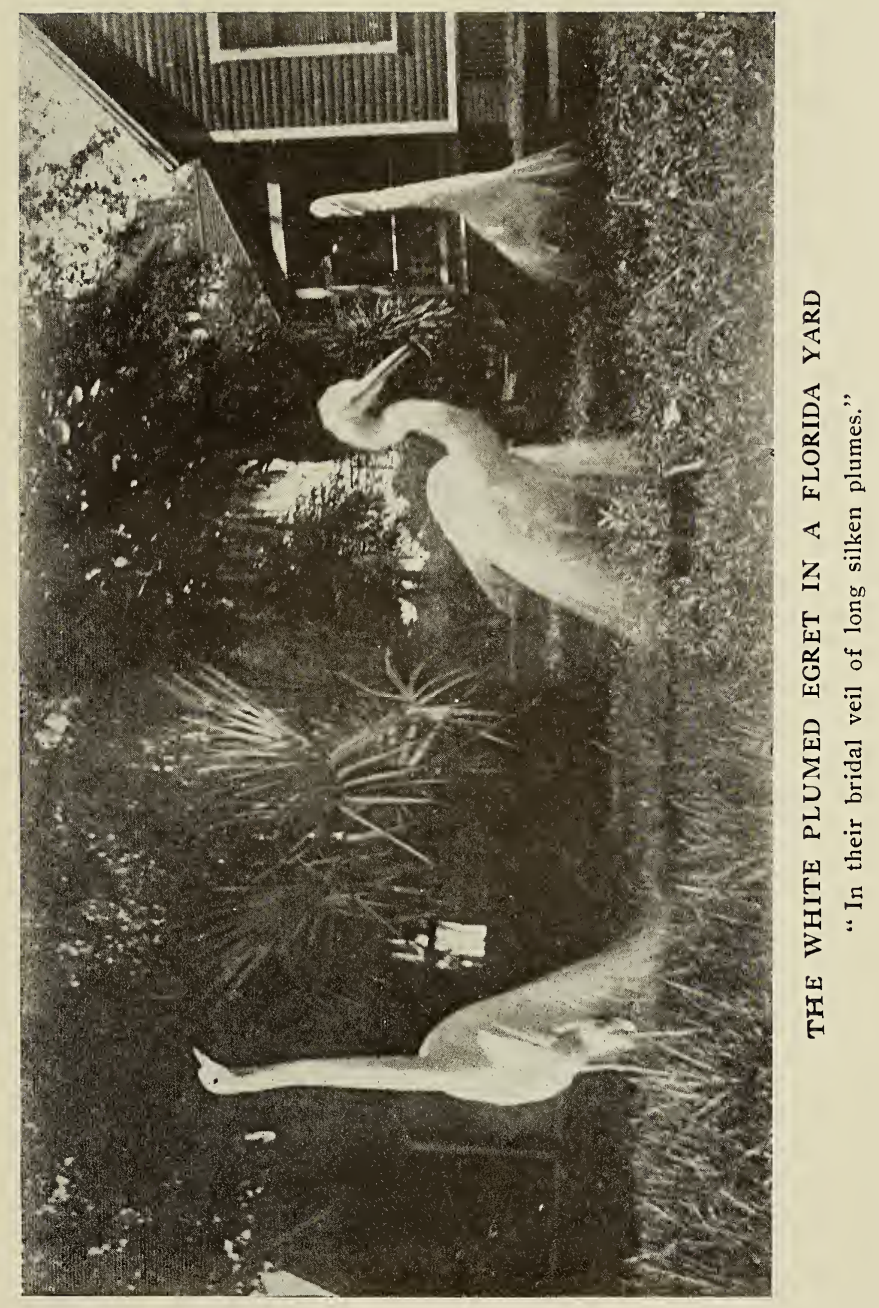





\section{THE SEMINOLES OF FLORIDA I8 I}

we be unmindful of that " charity which begins at home?" The panorama of Indian history passes before us, and we see nothing more tragic than the pictures of the wrongs endured by the native Americans. Let us then deal kindly with the tribes we have dispossessed, whose removal to the swamps has made room for our own enlargement. In the person of these descendants of a now disinherited race, who with shy, frightened faces still hide in the wilderness, we may yet atone in part for the tragedies of the past by making Florida a free, safe and Christian home for this patient and long-persecuted remnant of a once-powerful Indian nation.

May the almoner of justice, under the guidance of an overruling God, protect and keep and cherish these red children of the forest homes. 

PART III

Vocabulary 



\section{INTRODUCTION TO VOCABULARY}

In presenting the following words, phrases and sentences to the public, we beg to add a few explanations. The words have been obtained from the Indians themselves. To collect words from an Indian requires patience at any time, and in dealing with the Seminoles particularly so. The Florida Indian is suspicious of the white man, and until a confidence was established and a friendship formed, it was impossible to obtain any accuracy from him. To secure the words in this work methods were devised, in order to have the Seminole fully understand the collector, as well as to enable the collector to grasp with a

- certainty the Indian's meaning. As will be seen by a close study of the vocabulary, the noun does more than simply denote the thing to which it belongs; it also assigns to it some quality or characteristic. As for instance the word elephant. The Indian had never seen an elephant, but on being shown' one in a circus parade, after a careful thinking, he named it, "e-po-lo-wa-kee" - " heap long nose." Great latitude is thus permitted in an Indian vocabulary. On account of non-intercourse with a civilized race the Seminole language is very pure. Economy in speech is followed, the highest aim of the Indian being to express in a single word both action and object. Every cluster-word is a description or a defi- 


\section{I86 THE SEMINOLES OF FLORIDA}

nition. The study of an unwritten language finds its phonology difficult. In this collection, the words are spelled phonetically; the accent and division into syllables are indicated to assist the student to make the correct pronunciation. Not only were these words given in good faith by the Indians with the present use in view, but each succeeding year, as we visited the Glades for a hunt, the various members of the tribe showed decided interest in our note book, assisting in revising the words by going over and over again the Seminole meaning and accent. The Seminole has a keen sense of humor. As we gathered words and phrases many amusing incidents occurred, always at our expense and to the greatest merriment of the Indians.

To Tallahassee we are indebted for much of this vocabulary, as well as for many interesting incidents and fragments of the history; yet it was not until the fourth year of acquaintance that the old chief, beside the dying embers of our camp fire at the midnight hour, opened his heart and told the story of his people, their myths, religion, legends - their heartaches. The night was chilly, the old chief lost in his own earnestness drew his tunic closer about him, yet the writer could not say "it is late - you are cold." It was a golden opportunity; a word, the rustle of a branch and the current would have changed. Until daybreak, in his broken English Tallahassee told his story. Never before, nor ever since has such an occasion presented itself. 


\section{VOCABULARY 2}

\section{PERSONS}

SEMINOLE

Es-ta-chat-tee ............. Indian.

ENGLISH

Es-ta-had-kee $\ldots \ldots \ldots \ldots \ldots . . .6$ White man.

Es-ta-lus-tee ................ Negro.

Ho-non-waw $\ldots \ldots \ldots \ldots \ldots . . .$. Man.

Hoke-tee ...................Woman.

Ach-o-be-li-tee...$\ldots \ldots \ldots \ldots$. Old man.

Hoke-tee-li-tee $. . . \ldots \ldots . . . .$. Old woman.

Ho-non-wa-mi-nit-ti-tee .......... Young man.

Hoke-tee-ti-mi-nit-ti-tee .......... Young woman.

Che-pon-no-shi-tee ............. Boy.

Hoke-ti-chee ................. Girl.

Est-to-chee ................. Infant.

Ho-non-o-chee . ............... Male infant.

Hoke-to-chee...$\ldots \ldots \ldots \ldots$. Female infant.

Poke-taw ................. Twins.

E-hi-wa-o-chit-ee .............. Married man.

E-hi-was-ko ................ Bachelor.

E-hi-wa-se-ko ................Widower.

E-hi-lift-mus-chee $\ldots \ldots \ldots \ldots \ldots$. Widow.

E-he-see-ko ................ Old maid.

E-he-see-ko-hoke-ti-lee ........... The old people.

Es-tee-min-nit-tee $\ldots \ldots \ldots \ldots \ldots$ A great talker.

O-pa-na-ki-tee $\ldots \ldots \ldots \ldots \ldots \ldots$. A silent person.

Host-cope-e-taw . ............. Thief.

Host-cope-e-gost-chee . . . . . . . . Not a thief.

${ }^{1}$ In this vocabulary the words are arranged according to their subject or character, no attention being paid to alphabetical succession. 


\section{I88. THE SEMINOLES OF FLORIDA}

\section{PARTS OF THE BODY}

SEMINOLE

ENGLISH

E-caw ..................... Head.

E-caw-e-see ................. Hair.

E-caw-hos-pee ............... Crown of head.

Torso-faw $\ldots \ldots \ldots \ldots \ldots \ldots \ldots$. $\ldots$.

Ka-ho-waw .................. Forehead.

E-tox-lo-waw . ............... Eye.

Tose-lis-kee .................. Eye lash.

To-do-no-lup-pa-is-see ............ Eye brow.

Tode-le-wa-hos-pee ............. Upper eyelid.

Tode-le-list-la-hos-pee ............ Lower eyelid.

Hots-cote-es-caw . ............. Ear lobe.

E-hots-ko .................. Ear.

Hots-caw-pof-ef-caw . ........... Perforation in ear.

Hots-caw-ko-kee..$\ldots \ldots \ldots \ldots$. Opening of ear.

E-ho-po ................... Nose.

E-po-fo-nee . . . . . . . . . . . . Ridge of nose.

E-po-haw-kee ................ Nostril.

E-yan-i-waw . . . . . . . . . . . . Cheek.

No-ti-ka-is-see . . .............. Beard.

E-choke-o-waw ................ Mouth.

Choke-hos pon-a-paw ........... Upper lip.

Choke-hos-pee ................. Lower lip.

E-no-tee-ho-maw $\ldots \ldots \ldots \ldots \ldots$. Front teeth.

E-no-tee-lock-ko .............. Back teeth.

To-los-waw ................. Tongue.

E-to-ka-lo-swaw . .............. Saliva.

Sin-no-ka-nil-caw . . . . . . . . . . Throat.

No-ti-caw..$\ldots \ldots \ldots \ldots \ldots \ldots$. Chin.

No-ka-pee ................. Neck.

No-quif-pa-tock-ock-naw ..........Adam's apple.

E-naw-chee ................. Body. 


\section{THE SEMINOLES OF FLORIDA 189}

SEMINOLE

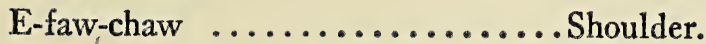

ENGLISH

Fo-lo-taw-pix-taw ............ Shoulder blade.

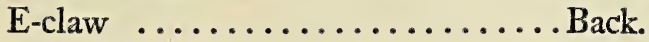

E-claw-fo-nee .............. Back bone.

E-hoke-pee .............. Breast of man.

E-pee-see . . . . . . . . . . . Breast of woman.

Im-po-loke-cho $\ldots \ldots \ldots \ldots \ldots$ Hip.

E-ho-cho-waw ............. Navel.

E-shock-paw ................. Arm.

In-clop-pe-claw . . . . . . . . . . Right arm.

Aw-clos-clin-aw .............. Left arm.

Ho-lo-wa-to-tee-ta-gaw $\ldots \ldots \ldots$. Arm pits.

Sock-pof-o-nee ............. Right arm above elbow.

Aw-kos-ko-nof-o-nee . ........... Left arm above elbow.

E-ko-chee ................ Elbow.

In-tee-ti-pix-tee-e-toke-kee-tay-gaw ..W Wrist.

In-tee-ti-pix-tee ............. Hand.

In-ko-faw ...................

In-tee-ta-pix-tee-e-naw-pa $\ldots \ldots \ldots$. . Back of hand.

In-ka-we-sa-kaw . . . . . . . . Fingers.

Som-kit-kee ............... Thumb.

Som-kil-smil-kaw ............. First finger.

In-ka-nock-klo-pa-ho-e-claw ....... Second finger.

In-ka-ho-klif-claw-such-lo ....... Third finger.

In-ka its-ho-chee-wa-chee ........ Small finger.

In-hits-kee-in-kose-es-waw ........ Finger nail.

In-ka-we-sock-ka-e-to-pee $\ldots \ldots \ldots$ Knuckle.

In-ka-yock-pee ............. Space between knuckles.

E-tol-kay ................. Rump.

Chee-hof-ee ................. Leg above knee.

E-tolk-wa-po-la-ko ............. Knee.

Tose-to-po-la-ko .............. Knee pan.

Chee-host-go-waw ..............eg below knee. 


\section{I90 THE SEMINOLES OF FLORIDA}

SEMINOLE

BNGLISH

E-lim-pock-ko ............... Calf of leg.

E-lay-toke-to-swaw $\ldots \ldots \ldots \ldots \ldots$. Ankle.

E-lit-ta-pix-tee-e-fo-cho-to-kee-not-ee .Instep.

Es-tel-e-po ................... Foot.

Es-tel-e-ho-faw . . . . . . . . . . . Sole of foot.

E-lich-es-caw . ................. Heel.

Es-tel-e-e-sa-caw . ............... Toe.

Es-tel-e-eeds-kee . ............... Large toe.

Es-tel-e-nock-clay-ho-e-claw ........ Second toe.

E-la-ni-ka-so-swaw . ............ Toe nail.

Chaw-taw .................... Blood.

Chaw-tee-fo-kaw $\ldots \ldots \ldots \ldots \ldots$. Vein or artery.

Istee-e-kol-pee..$\ldots \ldots \ldots \ldots \ldots$. Brain (man).

E-kol-pee .................. Brain.

E-ho-sil-waw ............... Bladder.

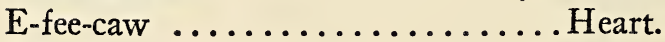

E-pof-caw..$\ldots \ldots \ldots \ldots \ldots$ Around the heart.

E-to-chee $\ldots \ldots \ldots \ldots \ldots \ldots \ldots$ Kidney.

In-hee-shock-e-taw .............. Lung.

E-lo-pee ................... Liver.

Im-pa-shaw $. . . \ldots \ldots \ldots \ldots . .$. Stomach.

In-ta-law $\ldots \ldots \ldots \ldots \ldots \ldots$ Rib.

In-ka-shock-a-tee .............. Pulse.

Es-tel-e-hop-o ............... Foot print.

Shon-aw-haft-bee ............... Skin.

Shon-aw-fon-ee ............... Bone.

Fix-chee-e-la-pots-kee . . . . . . . . . Intestines.

Cho-pock-e-taw $\ldots \ldots \ldots \ldots \ldots$. Scalp.

\section{DRESS AND ORNAMENTS}

Cot-to-po-kaw ................ Cap.

E-kof-kaw ................. Breech cloth. 


\section{THE SEMINOLES OF FLORIDA I9I}

\section{SEMINOLE}

ENGLISH

She-won-nock-e-taw ............Breech cloth belt.

Aw-fa-tee-kaw ................ Leggins.

Stil-i-pi-kaw . ................ Moccasins.

Som-po-chee ............... Basket.

Ech-e-taw ................ Blanket.

Lo-cus-haft-ee-pa-ta-kaw ........... Bear skin (robe).

E-cho-haft-ee-pa-ta-kaw .......... Deer skin (robe).

Cho-see ................... Buck skin or snake skin.

Cho-fee-haft-bee .............. Rabbit skin.

O-sho-aw-haft-bee .............. Beaver skin.

O-shon-aw-haft-bee $\ldots \ldots \ldots \ldots \ldots$. Otter skin.

Co-lo-waw .................... Paint.

Co-lo-waw-la-nee ...............Paint (yellow).

Co-lo-wa-lus-tee ................Paint (black).

Co-lo-wa-chaw-tee ..............Paint (red).

Shoke-shot-ta-pix-chee ............Pouch.

Stink-ko-shot-ti-tee-caw . .......... A ring.

Cop-a-to-ca-och-aco ............ Bare head.

Es-tel-e-pi-e-ca-och-a-co . . . . . . . . Bare foot.

E-ca-e-pee .................. Naked.

She-won-nock-e-ta-sa-lof-kaw ...... Knife belt.

Co-na-waw ................. Beads.

Hi-ef-cof-ka-taw . .............. Shirt.

Stil-a-pa-won-hee .............. Shoes.

Note-tes-chee ................. Handkerchief.

Es-ti-ha-kee .................. Picture.

Osh-aw-kil-caw-e-fa-caw .........Watch chain.

Osh-aw-kil-caw ..............Watch.

She-ma-caw ................. Fan.

Shit-ta-kee-caw..$\ldots \ldots \ldots \ldots$...... Walking cane. 


\section{I92 THE SEMINOLES OF FLORIDA}

\section{DWELLINGS, IMPLEMENTS, UTENSILS, ETC.}

\section{SEMINOLE}

Cho-co-ta-ti-yee ............. Village.

Cho-co-hum-co-see ............Wigwam.

E-how-kee ............... Door way.

We-chow-hi-lit ................ Spark.

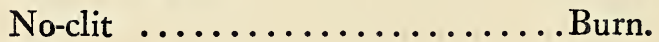

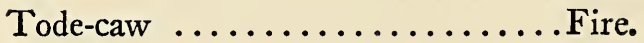

Tock-hot-chee .............. Fire wood (burning),

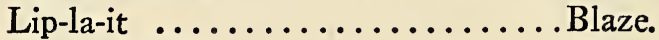

Toke-la-waw .............. Living coals.

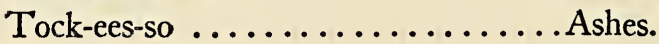

Eh-cho-chee ................ Smoke.

Aw-lock-a-taw-chaw-ho-tee .......My home.

Aw-ho-gee ............... Door way.

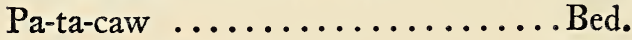

Shot-hote-caw ................ Door.

Cho-ko ................... House.

Ko-lo-kee ................. Lamp.

Osh-aw-kil-caw-lock-o .......... Clock.

To-paw .................... Floor.

Cho-ko-no-paw ................... Ceiling.

Cho-ko-shaw-hose-paw-caw .......W Wall.

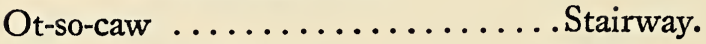

We-wa-ese-pay-lot-caw ......... Spring.

We-wa ................Water.

E-pee-lo-faw ................ Hommock (woods).

E-con-aw-aw-ho-pa-caw .......... Map.

See-la-hot-tit-taw ........... Railing.

Tode-ca-e-ho-tee .............. Stove.

We-wa-ho-tee ...............Water tank.

Ho-e-so-clope-pa-lock-a-naw ......W Wash bowl.

In-ka-e-to-shi-eets-caw ......... Towel. 
SEMINOLE

ENGLISH

To-how-how-waw $\ldots \ldots \ldots \ldots \ldots$ Trunk.

So-cose-caw . ................ Soap.

Sin-ti-ne-ta-pi-ee-to-caw . . . . . . . . Whisk broom.

Ees-cos-caw ................. Comb.

E-fa-ko-lock-o . . . . . . . . . . Rope (cable).

Shot-hit-go-chee .............. Glass tumbler.

Tose-to-lese-taw ..............Wagon.

Tose-to-lese-ta-pof-na-chee ......... Buggy.

Aw-ta-lit-taw ................ Clothes hooks.

E-shaw-ho-tee ................ Gun cover.

Chot-a-dox-cha-in-che ............ Arrow.

Bith-low ................... Canoe.

Sar-sho-e-fa-caw . ............... Fish line.

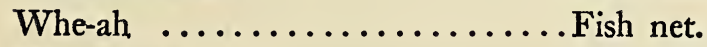

Hi-eets-caw $\ldots \ldots \ldots \ldots \ldots \ldots$. Accordeon.

Tock-kee-so ..................Ashes.

Buch-es-waw ................Ax.

Polk-ko .................... Pottery.

Le-ho-chaw ................. Pot of pottery.

Chat-o-lon-ee ................Brass.

Che-to-ko-lope-lon-ee ............ Gold.

Sha-teek-e-naw-yaw . ............ Silver.

Shot-to $\ldots . \ldots \ldots \ldots \ldots \ldots \ldots$. Iron.

Hi-lo-chee ................. Cup.

We-wa-sis-ca-taw ............. Dipper.

Sto-caw .................... Bucket.

E-slof-ka-pee ............... Knife handle.

E-slof-ka-e-ock-shaw . ............Knife point.

E-slof-ka-e-in-fos-kee ............ Knife edge.

Sa-lof-ka .................. Knife.

Chum-chaw-cha-lock-ko .......... Bell.

Chum-chaw-ko ............... Small bell.

Shif-fon-waw...$\ldots \ldots \ldots \ldots$........ 


\section{I94 THE SEMINOLES OF FLORIDA}

\section{SEMINOLE}

ENGLISH

To-shay-sil-caw $\ldots \ldots \ldots$ Whang (for sewing moccasins). We-hop-caw ................. Pillow.

To-hi-o-waw...$\ldots \ldots \ldots \ldots$. Valise.

To-ho-to-waw ............... Powder.

Ho-tee ..................... Powder can.

Shaw-toke-e-naw-waw ...........Money.

To-ko-naw-shaw-tee ............ One cent.

Na-kop-po-chee ............... Ten cents.

Con-shot-go-ho-ko-lin ............ Fifty cents.

Chalk .................. Twenty-five cents.

To-ko-naw-wa-hum-kin ......... One dollar.

To-ko-naw-wa-cha-kee-bir ........ Five dollars.

E-sho-gaw ................. File.

Ees-how-ees-caw . ............. Key.

Ees-pas-caw ................ Broom.

Chot-to-go-chee ................ Mallet.

Op-pee $\ldots \ldots \ldots \ldots \ldots \ldots \ldots$ Broomstick.

Tock-o-take-go-chee $\ldots \ldots \ldots \ldots \ldots$ Common stick.

Im-mi-lay-sha-taw $\ldots \ldots \ldots \ldots \ldots$ Court plaster.

Tose-ka-lof-caw ............... Plane.

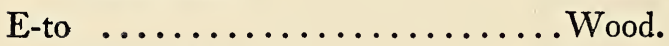

Tock-kin-o-shaw . . . . . . . . . . Brick.

Ok-e-fots-chay $\ldots \ldots \ldots \ldots \ldots$. Sea shell.

To-hop-kee ................... Fence.

Ho-lo-paw . . . . . . . . . . . . Walk (pavement).

Chat-o-ko-cho . . ............ Cartridge.

Hi-eets-e-fa-caw . . ............ Guitar string.

O-like-a-taw $\ldots \ldots \ldots \ldots \ldots \ldots$ Chair.

To-paw .................... Floor.

Es-ti-ha-kee ................ Picture.

Tol-lo-faw ................. Town.

Ist-fon-o-kee-taw $\ldots \ldots \ldots \ldots \ldots$. Rocking chair.

E-skil-caw ................. Compass. 


\section{THE SEMINOLES OF FLORIDA I95}

SEMINOLE

ENGLISH

Shock-shaw-e-taw ............ Dip net

Ti-sos-so-chee $\ldots . \ldots \ldots \ldots \ldots . .$. Pin.

Ees-la-pode-caw . .............. Needle.

Ees-ti-no-tee-some-fo-tee-taw . ...... Tooth pick.

Shoke-chaw, ................. Sack.

It-to-tee-ish-fo-gaw $\ldots \ldots \ldots \ldots$. Ice saw.

It-to-tee-butch-es-waw $\ldots \ldots \ldots \ldots$. Ice hatchet.

It-to-tee-in-so-go $\ldots \ldots \ldots \ldots \ldots$. Ice house.

It-to-tee-saw-gaw $\ldots \ldots \ldots \ldots \ldots$. Ice machine.

It-to-tee-ock-les-waw $\ldots \ldots \ldots \ldots$. . Ice moulds.

It-to-tee-she-lot-caw . . . . . . . . . . . Ice tongs.

It-to-tee-we-waw $\ldots \ldots \ldots \ldots \ldots$. Ice water.

To-fo-ga-leg-a-mee . ............. Saw dust.

To-fo-la-hi-lee ................ Cord wood.

To-to-lese-pof-a-naw-o-cho-go . . . . . Railroad car.

Phon-e-o-hop-ee $\ldots \ldots \ldots \ldots \ldots$. . Fishing pole.

Sho-a-los-ga-taw $\ldots \ldots \ldots \ldots \ldots$. Hammock (to swing).

Ko-lo-kee-e-hóo-tee ............... Lantern.

Tol-lot-to-chee ................ Brush.

O-pa-tock-o $\ldots . . . \ldots \ldots \ldots . .$. . Saddle.

E-ho-e-lit-taw ................ Stirrup.

She-lop-ko-chif-ko-taw .......... Spur.

Ach-aw-kil-caw-lock-o ........... Clock.

E-sho-e-caw $\ldots \ldots \ldots \ldots \ldots \ldots$. Hoe.

Hot-cus-waw ................ Iron kettle.

Ta-pate-go-chee ............... Pistol.

Ich-chaw $\ldots \ldots \ldots \ldots \ldots \ldots$. . . .

E-chaw ................... Rifle.

To-lo-to-lon-e ............... Cap (percussion).

To-hote-to-waw ............... Powder.

Wee-aw ................... Seine.

Sa-lof-ka-chop-ka ............. Sword.

Sa-lof-ka-chee ................Knife (small). 


\section{I96 THE SEMINOLES OF FLORIDA}

SEMINOLE

ENGLISH

Sa-lof-ka-fots-kee .............. Knife (sharp).

Sa-lof-ka-tof-nee ............... Knife (dull).

\section{FOOD}

To-lee-ko ................... Oatmeal.

O-chee-tot-o-la-go-chee ............ Corn bread.

Tot-o-lo-som-po-chee ............ Cake.

Pish-waw ................... Meat.

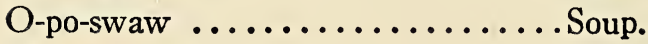

Tock-a-la-kee ................. Bread (flour).

Och-chee-lo-wat-kee ............ Corn (green).

Wa-ka-pish-aw ................. Milk.

Chum-pee ................... Honey.

Yel-la-haw .................. Lemonade.

Fo-chum-pee ................ Bees and honey.

Ist-sa-tock-ko . .............. Cauliflower.

O-ko-to .................... Radish.

Oke-chon-tel-o-ko-nee ............ Salt.

Il-la-haw ................... Orange.

Itch-on-e-haw $\ldots \ldots \ldots \ldots \ldots$. Tallow.

Ho-waw ................... Pepper sauce.

E-cho-pish-waw .............. Deer meat.

Chil-i-hos-waw ............... Pineapple.

Wa-ka-pish-aw-tock-o-la-kee ....... Cheese.

Tol-o-so-caw ................ Cocoanut.

Chos-chee-lock-o .............. Pumpkin (whiteman's).

Chos-chee .................. Pumpkin (Indian).

E-po-see-waw ................ Gravy.

Fit-chee .................. Sausage.

We-len-tel-lo ................... Banana.

Hil-o-cho-waw $\ldots \ldots \ldots \ldots \ldots \ldots$ Chewing gum.

Wa-ka-pish-a-ne-haw ............ Butter. 


\section{THE SEMINOLES OF FLORIDA}

SEMINOLE

ENGLISH

Wa-ka-pish-e-e-tok-chee .......... Sour milk.

Warka-fit-chee ................ Sausage (beef).

Suck-a-fit-chee $\ldots \ldots \ldots \ldots \ldots$. . . Sausage (pork).

Ho-tes-kot-tee-hot-kee ............ Flour.

Whit-lo-ko ................ Oysters.

Aw-haw ................... Potato (sweet).

Tol-o-la-go-chee ............. Biscuit.

Aw-hot-to-pox-to-chee ........... Potato (Irish).

Cot-lo-chee ................. Sardines.

Aw-pis-ta-lake-a-to-me . . . . . . ..... Potted ham.

Tock-a-la-kee-chom-paw .......... Ginger cake (large).

Ho-maw ................... Pickles.

Pe-kon-o-soch-o-chee . ............ Cherries.

Tock-a-fon-waw ............... Filbert.

Shot-o-lock-o .................. Apple.

Chil-loos-wa ................ Grapes.

Tock-a-la-kee-chum-po-chee ........ Cake (small).

\section{COLORS}

Lus-tee .................... Black.

Ho-lot-tee...$\ldots \ldots \ldots \ldots$. . Blue.

Ho-ko-lon-i-tee ............... Brown.

Sho-po-ka-hot-ka-chee ........... Grey.

Pi-e-lon-o-maw . ............... Green.

Chat-tee .................... Red.

Hot-ka-tee $. . . \ldots \ldots \ldots \ldots . .$. White.

\section{NUMERALS}

Hum-kin .................. One.

Ho-ko-lin $\ldots \ldots \ldots \ldots \ldots \ldots$. Two.

Too-chin...$\ldots \ldots \ldots \ldots$. . . . Three.

Os-tin ....................... Four. 


\section{I98 THE SEMINOLES OF FLORIDA}

\section{SEMINOLE}

ENGLISH

Chaw-kee-bin ................. Five.

A-pa-kin ..................

Ko-lo-pa-kin ................. Seven.

Chin-na-pa-kin ............... Eight.

Os-ta-pa-kin $\ldots \ldots \ldots \ldots \ldots \ldots$........ Nine.

Pa-lin .................. Ten.

Pa-lin-hum-kin-hum-kin .......... Eleven.

Pa-lin-hum-kin-ho-ko-lin ......... Twelve.

Pa-lin-hum-kin-too-chin .......... Thirteen.

Pa-lin-hum-kin-os-tin ............ Fourteen.

Pa-lin-ho-ko-lin ............... Twenty.

Pa-lin-ho-ko-lin-hum-kin ......... Twenty-one.

Pa-lin-ho-ko-lin-too-chin ......... Twenty-three.

Pa-lin-too-chin . .............. Thirty.

Pa-lin-os-tin . ................ Forty.

Pa-lin-chaw-kee-bin ............. Fifty.

Pa-lin-a-pa-kin ............... Sixty.

Pa-lin-ko-la-pa-kin ............. Seventy.

Pa-lin-chin-na-pa-kin $\ldots \ldots \ldots \ldots \ldots$. Eighty.

Pa-lin-os-ta-pa-kin .............. Ninety.

Chope-kee-hum-kin ............. One hundred.

Chope-kee-ho-ko-lin ............ Two hundred.

Chope-kee-too-chin-ee ........... Three hundred.

\section{DIVISIONS OF TIME}

Ti-ose-go-chee.$\ldots \ldots \ldots \ldots \ldots$. . . . . Ti-ose-go-lock-o . . . . . . . . . . Second moon (September). E-ho-lee .................. Third moon (October). Si-lof-slop-ko . ............. Fourth moon (November). Si-lof-so-kee . ................ Fifth moon (December). Ho-ti-lee-has-ee ............... Sixth moon (January). Ti-sot-to-chee.$\ldots \ldots \ldots \ldots \ldots$ Seventh moon (February). 
SEMINOLE

\author{
ENGLISH
}

Ti-sot-to-lock-o . ................ Eighth moon (March).

Kee-hos-ee .................. Ninth moon (April).

Got-so-hos-ee . . . . . . . . . . . . Tenth moon (May).

Hi-yote-chee . ................. Eleventh moon (June).

Hi-yote-lock-o . ............. Twelfth moon (July)

Mis-kee-hum-kin ............. One year.

Ha-lits-chey..$\ldots \ldots \ldots \ldots \ldots$. Moon.

Nit-taw $\ldots \ldots \ldots \ldots \ldots \ldots$. Day.

Nist-lee $\ldots \ldots \ldots \ldots \ldots \ldots \ldots$. Night.

U-mus-ka-taw $\ldots \ldots \ldots \ldots \ldots \ldots$. Dark.

Pox-son-gay $\ldots \ldots \ldots \ldots \ldots \ldots$. Yesterday.

Pox-son-gay-lim-pix-son-gay ...... Day before yesterday.

A-pox-see-lim-pox-say-nist-lee . . . Day after to-morrow night. Mo-shon-nit-taw ............. Today.

A-pox-see ................. To-morrow.

A-pox-see-lim-pox-say $\ldots \ldots \ldots \ldots$. Day after to-morrow.

Mis-kee-hum-kee .............. Next year.

Mo-shon-mis-kee . ............ This year.

Mis-kee-ho-ko-lin . ............ Two years.

Mis-kee-too-chin-aw ............ Three years.

Nit-ti-chow-go-hum-kin .......... One week.

Nit-ti-chow-go-ho-ko-lin ........ Two weeks.

Nit-ti-chow-go-too-chin-aw ....... Three weeks.

Nit-ta-hum-kin . ............. One day.

Nit-ta-ho-ko-lin . ............ Two days.

Nit-ta-too-chin-aw $\ldots \ldots \ldots \ldots \ldots$ Three days.

Nit-ta-os-tin ................ Four days.

Mo-shon-nist-lee .............. To-night.

A-pox-see-nist-lee . . . . . . . . . To-morrow night.

Mo-cho-hos-see ............... This moon.

Hos-see-hum-kee ............... Next moon 


\section{THE SEMINOLES OF. FLORIDA}

SEMINOLE

ENGLISH

Osh-aw-kil-hum-kin ............ One o'clock.

Osh-aw-kil-ho-ko-lin .Two o'clock.

ANIMALS, PARTS OF BODY, ETC.

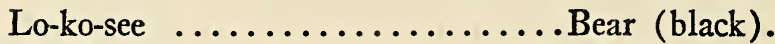

Ko-wat-go-chee ................

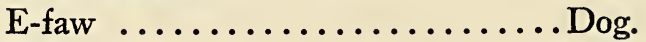

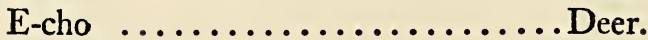

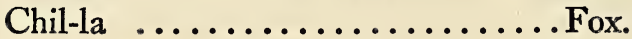

E-cho-wa-a-taw $\ldots \ldots \ldots \ldots \ldots$. . . . .

Su-caw-pin-si-law ............Hog (wild).

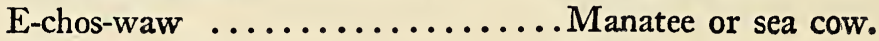

Tock-o ....................Mole.

O-shen-aw ................... Otter.

Su-caw-hot-caw $\ldots \ldots \ldots \ldots \ldots$. Opossum.

Ches-she ................... Rat.

Cho-fee .................... Rabbit.

Cho-fee-chaw-hot-ee ........... Rabbit (grey).

Wood-ko .................Raccoon.

Klo-hi-lee ................. Squirrel.

Klo-hot-go-chee .............. Squirrel (grey).

Klo-hi-lee-chaw-tee ............ Squirrel (red).

Yee-haw ..................Wolf.

Kon-kla-po-chee ............ Chameleon.

E-cho-yi-pee ................Antlers.

Wa-ka-e-fo-nee ............... Bone (cow).

Fit-chee-law-pots-kee ........... Entrails.

Nee-haw .................... Fat.

Wa-ka-haft-bee ................ Hide (cow).

Yi-pee ..................Horn.

Fit-chee-lock-o .............. Stomach.

E-hot-chee ............... Tail. 


\section{THE SEMINOLES OF FLORIDA 20r}

\section{SEMINOLE}

ENGLISH

E-no-tee $\ldots . . . \ldots \ldots \ldots \ldots$. . Teeth.

E-po-lo-wa-kee ................ Elephant.

Chil-lock-o .................. Horse.

Chil-lock-o-chee $. . . \ldots \ldots \ldots . .$. Colt.

Chil-lock-o-pi-e-caw .............Mule.

Wal-ka-ho-non-waw ............ Ox.

Wal-ka-chee .................. Calf.

Suck-aw ....................Hog.

Po-sha-chee .................. Cat.

Yep-e-fa-e-caw . ................ Sheep.

E-fa-chee $\ldots \ldots \ldots \ldots \ldots \ldots \ldots$. Puppy.

Cho-wa-taw...$\ldots \ldots \ldots \ldots$......... Goat.

Wal-ka ................... Cow.

\section{BIRDS}

O-so-waw $. . . \ldots \ldots \ldots \ldots \ldots . . .$. Bird.

O-chot-aw .................. Black bird.

Shock-kil--law ............... Black bird (red wing).

Wa-to-law ..................Whooping crane.

O-shaw-o-waw $\ldots \ldots \ldots \ldots \ldots$. . . . .

Hi-lo-lo ................... Curlew.

Hi-lo-lo-chaw-tee . . . . . . . . . . Curlew (pink).

Posh-e-ho-we ................ Dove.

Fo-cho ................... Duck.

Hat-tit-e-fon-caw ............. Eagle.

Sho-caw ................... Hawk.

Sho-ko-chee ................ Sparrow hawk.

Hos-cho-kee-waw . ............. Fish hawk.

Wak-ko-lot-ko ................. Heron (great blue).

Wak-ko-lot-ko-o-hi-lot-tee ..........Heron (little blue).

Fost-chi-taw ................ Red bird.

Hi-lo-lo ................... Ibis (white). 


\section{THE SEMINOLES OF FLORIDA}

SEMINOLE

ENGLISH

Tos-chee .................. Jay (blue).

Pen-na-waw . ................ Turkey.

We-hot-ko-fo-sho-wo-chee ......... Snipe.

Eash-pock-a-waw ............... Robin.

Fost-chi-taw ................. Red bird.

Sho-lee ................... Vulture.

Sho-lee-pee-los-pes-ko ...........Vulture (black).

Chip-ee-lop-law .............Whippoorwill.

Fo-a-kee .................. Quail.

Pen-nit-kee ................. Turkey hen.

Pen-na-waw-en-to-wee ........... Turkey beard.

Pen-cha-ho-gaw $\ldots \ldots \ldots \ldots \ldots$. Turkey cry.

Pen-ni-chaw ................ Turkey gobbler.

Fo-shon-nits-kaw ............. Rookery.

Shee...$\ldots \ldots \ldots \ldots \ldots$. . . . . . .

Lo-cha-e-stow-cha-kee . ..........Egg.

O-cho-ko .................. King fisher.

Ho-shock-e-a-caw . . . . . . . . . . Limkin.

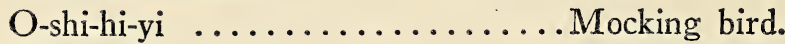

E-fo-law .................. Owl (schreech).

Pot-see-lon-ee ................. Paroquet.

To-to-lo-chee ............... Chicken.

O-shot-caw $\ldots \ldots \ldots \ldots \ldots \ldots$. $\ldots$.

O-shot-co-chee $\ldots \ldots \ldots \ldots \ldots \ldots$. Heron (little white).

O-pal .................... Owl (eared).

E-chee-pa-hot-tee .....M.Mother Cary's chicken (Petrel).

\section{FISH AND REPTILES}

Sar-sho $\ldots \ldots \ldots \ldots \ldots \ldots$.............

Sar-sho-o-kee-lon-waw . .......... Cat fish.

Whit-lo-ko ................ Oyster.

Shar-lo .................. Trout. 


\section{THE SEMINOLES OF FLORIDA 203}

\section{SEMINOLE}

ENGLISH

Sar-sho-chee ................Minnow.

Shup-sho-chee ................Pickerel.

Al-la-pa-taw ................. Alligator.

Aw-pa-to-naw ................ Frog.

$\left.\begin{array}{l}\text { Chit-ta-mic-co } \ldots \ldots \ldots \ldots \ldots \\ \text { Chit-ko-la-la-go-chee } \ldots \ldots \ldots\end{array}\right\}$ or $\left\{\begin{array}{l}\text { Chief of snakes. } \\ \text { Rattle snake. }\end{array}\right.$

Ko-tee ................... Toad.

Chit-ta-lus-tee .............. Black snake.

Aw-shock-o-law .............. Snail.

Ho-lock-waw ............. Turtle (soft shell).

Lo-chaw ................ Turtle (land).

Chit-ta-lock-a-chee ............ Snake (spotted).

O-co-la-chit-ta ................

Skin-cho-caw ................ Frog (tree).

Gotch-es-waw .............. Turtle.

\section{INSEC'TS}

Tock-o-cha-cha-tee .............Ant (red).

Tock-o-cha-lus-tee ............Ant (black).

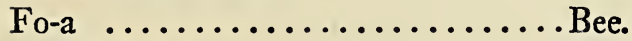

Chil-lock-o-fo-a ................Bee (drone).

Cuff-ko ...................Flea.

Cho-naw ................... Fly.

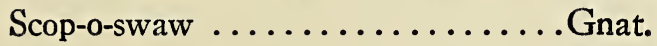

A-caw-ko-taw ................. Grasshopper.

Chil-lock-o-do-no ............. Horse fly.

Taw-fo ....................... Katy-did.

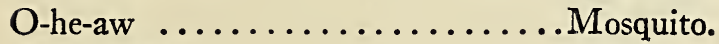

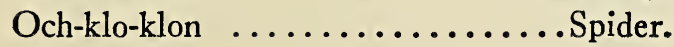

U-e-cot-taw ...................

Och-o-klon-we-ahr ............ Spider web. 


\section{THE SEMINOLES OF, FLORIDA'}

\section{SEMINOLE}

ENGLISH

To-ka-tes-kee-at-tee-lo-e-waw ...... Silk worm. Soke-so ................... Beetle (black).

\section{PLANTS}

Lock-e-tum-ba-e-cee ............ Oak leaf.

Ech-to-fa-la-ha-lee .............. Chip.

E-to .........................

Cho-lee-saw ................. Pine leaf.

Im-pock-pock-ee .............. Flower.

Pi-hee .................... Grass.

Gatch-ho-ho-e-claw ............. Blackberry.

Aw-won-aw ................. Willow tree.

Chit-ta-hum-pe-ta .............. Snake plant.

Til-e-ko ................... Oats.

Shot-i-pee...$\ldots \ldots \ldots \ldots \ldots$........ Persimmon tree.

Shot-taw ...................Persimmon.

Shot-o-nin-kla ...............Persimmon seed.

Gotch-o ....................Poison vine.

'Aw-shen-lock-o ................Air plant.

Aw-shen-waw ................... Moss.

Shil-o-fo-haw $\ldots \ldots \ldots \ldots \ldots \ldots$. Water lily.

We-sho .................... Sassafras.

Tol-o-lock-o ................Palmetto (cabbage tree).

Tol-o-chee ............ Palmetto (young cabbage-tree).

Tol-o-neck-la ................. Palmetto seed.

She-hop-paw ................ Saw palmetto.

Aw-shit-ta-taw ................ Gall berries.

Aw-tock-claw. .................Weed.

Chaw-fo-ka-naw ..............Huckleberries.

Hi-lis-hot-kee ............... Ginseng.

He-swan-i-hit-caw ............ Quinine.

Gout-lock-o ................ Cactus. 


\section{THE SEMINOLES OF FLORIDA 205}

SEMINOLE

ENGLISH

Com-to-lock-o .................Peanut.

Ti-fum-bee .................. Onion.

Hee-chee ................... Tobacco.

O-chee-o-pee $. . . \ldots \ldots \ldots \ldots . . .$. Hickory tree.

Kee ....................... Mulberry tree.

Hatch-in-e-haw..$\ldots \ldots \ldots \ldots$. Cypress tree.

E-la-hock-o ............... Shaddock (grapefruit).

\section{THE FIRMAMENT - PHYSICAL PHENOM- ENA, ETC.}

Go-chee-som-po-lock-o ...........Large star.

Go-chee-som-pol-e-poch-go-chee ...... Small star.

Cho-go-lof-caw ............... Seven stars.

Ho-nit-claw.$\ldots \ldots \ldots \ldots \ldots$........ North star.

Wa-hit-law..$\ldots \ldots \ldots \ldots \ldots$... South star.

Ho-so-shaw . ................. East star.

Aw-hil-lot-caw ...............West star.

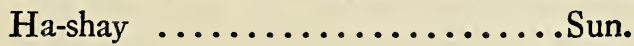

Hit-to-tee $\ldots \ldots \ldots \ldots \ldots \ldots \ldots$. Frost.

It-to-tee $\ldots \ldots \ldots \ldots \ldots \ldots \ldots$ Ice.

We-wa ...................Water.

Os-e-caw $\ldots \ldots \ldots \ldots \ldots \ldots \ldots$. Rain.

Ti-nit-kee ................. Thunder.

Ot-to-e-hot-tit $\ldots \ldots \ldots \ldots \ldots \ldots$. Lightning.

Go-ti-lee ..................Wind.

Ha-notch-e-fo-law . ............Whirlwind.

E-ho-tee ................... Ground.

O-ti-lee-lock-o ............... Storm.

Ha-shay-shay-pock-taw-lo-gaw . . .... Eclipse of the sun.

Ho-nit-chaw ................ North.

Ha-so-saw $\ldots \ldots \ldots \ldots \ldots \ldots \ldots$. East.

Wa-ha-law ................... South.

Op-a-lock-aw ...............West. 


\section{THE SEMINOLES OF FLORIDA}

SEMINOLE

ENGLISH

Ha-lits-cha-shay-pock-ta-lo-gaw ....Eclipse of the moon.

Hi-yi-tee-e-chaw $. . . \ldots \ldots \ldots . . .$. Morning star.

E-pof-kee .................. Evening.

Hi-e-ta-ma-es-chee . ............. Heat.

Chit-cho ................... Dew.

Ho-lo-chee .................A cloud.

\section{KINSHIP}

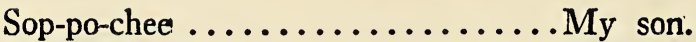

Chat-hos-tee .................My daughter.

Solk-go-chee .................My father.

Sots-kee .................... My mother.

E-chock-o-tee ................. Brother.

E-cho-see $\ldots \ldots \ldots \ldots \ldots \ldots$. . . .

E-la-ha .................... Brother (older).

Cho-wen-waw ............... Sister.

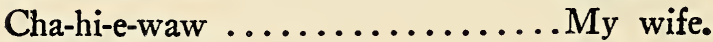

Squaw ....................Wife.

Picc-a-nin-ny $\ldots \ldots \ldots \ldots \ldots \ldots$ Child.

\section{VERBS, PHRASES, SENTENCES}

Ah-ho-chee...$\ldots \ldots \ldots \ldots$........ To plant.

Tote-ca-taw $\ldots \ldots \ldots \ldots \ldots \ldots$. To whistle.

E-lo-chaw...$\ldots \ldots \ldots \ldots \ldots$. To date.

Lop-ko ....................Make haste.

Ah-mos-chay ................ To give.

Chim-moc-co-dos-chay . .......... Not to give.

Hum-bi-da-lon-es-chay ........... To feed.

Yi-es-chay .................. To sell.

Neich-hi-es-chee.$\ldots \ldots \ldots \ldots \ldots$. Not to buy.

Hock-ka-eet-kit .............. To cry.

Op-peel-it ................. To laugh. 


\section{THE SEMINOLES OF FLORIDA 207}

\section{SEMINOLE}

ENGLISH

E-hi-e-kit $\ldots \ldots \ldots \ldots \ldots \ldots$. To sing.

Fi-i-it-lot-es-chee $\ldots \ldots \ldots \ldots \ldots$. To hunt.

Oh-in-i-it ................ To smell.

Clot-la-klip-chay . ............. To break.

Sop-pa-lon-es-chay $\ldots \ldots \ldots \ldots \ldots$. To sleep.

He-ches-chee ................ To see.

Im-po-hos-chee.$\ldots \ldots \ldots \ldots \ldots$. To hear.

Ah-es-chay...$\ldots \ldots \ldots \ldots$. . . .

Hi-e-pus $\ldots \ldots \ldots \ldots \ldots \ldots$. To go.

Chi-yot-chit ................ To like.

Aw-lock-chay $\ldots \ldots \ldots \ldots \ldots \ldots$. To come.

Cha-ho-sit .................. Forgot.

O-ko-sit ...................Wash.

He-chus-chee...$\ldots \ldots \ldots \ldots$. . . . .

Fit-kon-nit $\ldots \ldots \ldots \ldots \ldots \ldots \ldots$. Wait.

Hal-wuk $\ldots \ldots \ldots \ldots \ldots \ldots \ldots$. It is bad.

Hink-las ................... It is good.

Hi-o-e-pus-chay $\ldots \ldots \ldots \ldots \ldots$. Two go.

Hi-op-pee-pox-es-chay $\ldots \ldots \ldots \ldots$. Three or more go.

I-wox-chee ....................

Aw-mul-cay .................. All come.

No-chip-os-chay.$\ldots \ldots \ldots \ldots \ldots$. Go sleep (you).

Clot-la-klip-chay .............. Broken (to break).

Sup-pa-lon-es-chay ............. take.

Chi-ho-ches-chee .............. I am lost.

Che-ho-shar ................. You are lost.

E-wa-kee-pa-lon-es-chay ..........Lie down, but not to sleep.

Hum-kin-mi-si-e-pit ............ Take one.

Ye-hi-e-pa-taw . .............. To sing.

So-toke-kee-na-aw-aw-mun-chee ....Give me money.

Hi-e-pus-chay $\ldots \ldots \ldots \ldots \ldots \ldots$. I go.

Ot-som-ka-taw $\ldots \ldots \ldots \ldots \ldots \ldots$. To go up steps.

Hi-top-ka-taw $\ldots \ldots \ldots \ldots \ldots$. To go down steps. 


\section{THE SEMINOLES OF FLORIDA}

SEMINOLE

ENGLISH

Hock-it ................... To whistle.

Cho-ho-sit ................. Forgot.

Chi-yot-chee ................ I want.

E-see-op-cop-e-taw $\ldots \ldots \ldots \ldots \ldots$ To ride.

Chee-yi-chee..$\ldots \ldots \ldots \ldots$. . Do you want?

Mot-to .................. Thank you.

Es-tel-e-pi-e-ka-u-cha-ko-ot-e-he ..... To put moccasins on. Kit-lix-chay...$\ldots \ldots \ldots \ldots$. . . . . .

Kit-li-es-chay ............... know.

Aw-kay-lot-kit ............... Go in.

Lop-ko-sin-ot-tos-chay . .......... Come quick.

Chee-to-gaw ................ To pole a boat.

Scof-gaw ................. To row a boat.

Hum-pux-chay-hum-pee-taw ....... You eat plenty.

No-chee-pa-lon-es-chay . .......... am going to sleep.

Sa-lof-ka-chop-kaw . . .......... My knife is large (sword).

Sa-lof-ka-chee ................My knife is small.

A-pok-es-chay ................ All sit down.

No-chip-os-chay $. . . \ldots \ldots \ldots . . .6$ Go sleep (you).

Che-mo-on-ot-es-chay . ............Are you sleepy?

I-hoo-es-chay $\ldots \ldots \ldots \ldots \ldots \ldots \ldots$ Let us go.

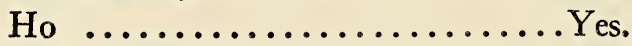

Li-kus-chay $\ldots \ldots \ldots \ldots \ldots \ldots$. . Sit down.

Hi-top-cay-ta-li-kus-chay . . . . . . . . Sit down on steps.

No-chit-pay-lon-es-chay..$\ldots \ldots \ldots$. Lie down and sleep.

Its-kee-e-i-chee-tok-naw . . . . . . Mother wants to keep him.

In-ka-o-ko-sit $\ldots \ldots \ldots \ldots \ldots \ldots$ Wash hands.

Mi-e-taw . ................ Tall (tree).

Che-mi-hee.$\ldots \ldots \ldots \ldots \ldots$. Grow (you or me).

Che-mi-hee-ta-mi-hee-cha-mi-he-taw .Grow very tall. Aw-ne-chee-mi-he-taw ..........I grow. 


\section{THE SEMINOLES OF FLORIDA 209}

SEMINOLE

ENGLISH

I-ti-it-tot-chi-mi-he-taw-mi-he-tawte-hee

\} I will grow tall.

Ha-tee-e-tew-chee-hick-chay-hit-eschay

Glad to see you.

E-cho-lid-kit-he-chus-chee ......... I saw deer run.

E-cho-ti-een-lid-kit-he-chus-chee .... I saw deer run fast.

E-cho-lid-kit-smi-hi-ko-in-in-he-chuschee

\} I saw deer run slow.

E-cho-yak-op-po-sit ............ Deer walk.

E-cho-yak-op-po-sit-hi-chus-chee ....I saw the deer walk.

E-cho-mo-chon-it-ta-we-wa-ah-kay- TTo-day I saw a deer go

lot-kit-o-mi-e-it-i-in-he-chus-chee $\}$ in the water and swim.

Il-lich-is-caw ............. Did you kill it?

Lop-fi-eets-chay .............. Let us hunt.

Im-po-hitch-caw . ........... Do you hear?

He-chos-kos-chay ............. can't find it.

To-pa-li-kus-chay ............. Sit on floor (you).

Pish-wa-chi-us-chee ........... I want some meat.

Aw-som-es-chee-aw-pish-waw ...... Pass me the meat.

Lox-a-dox-chay .............. You lie.

Is-chay-to-ma-es-chee $\ldots \ldots \ldots \ldots$ Wind blew hard.

He-a-maw . ................. Come here.

Suck-chay ................. All gone.

Aw-pok-es-chay $\ldots \ldots \ldots \ldots \ldots$. All sit down.

Ha-sha-col-lock-tit ............ Sun gone down.

Ha-shari-sit ..................

To-ko-naw-yo-ko-dos-chay .........Money, no sell 'em.

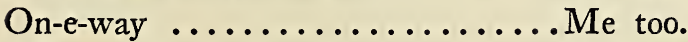

Un-gaw $\ldots \ldots \ldots \ldots \ldots \ldots \ldots$. All right.

Nock-a-tee ...............What is it?

Stom-a-taw ...............Which way?

Aw-lip-ka-shaw ..................

Aw-tee-tus-chee .................. By-and-by. 


\section{Io THE SEMINOLES OF FLORIDA}

SEMINOLE

ENGLISH

Ho-lo-wa-gus .................. good.

Hi-lip-pit-ka-shaw ........... How are you?

Som-mus-ka-lar-nee-shaw . ........ Good luck.

Ya-maw ................ This way.

Hock-es-chee ................. Bird cry.

Chi-yot-chit $\ldots \ldots \ldots \ldots \ldots \ldots$. L L .

Chee ................... Young or small.

O-fun-net-taw ............. Long time.

En-cha-mun-chay ...........Well or good.

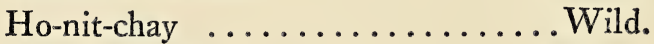

Ni-hit-tus-chay .............. Fat.

Wi-o-kee-tus-chay .............. Poor.

Es-to-chee-hock-a-effee ........... Baby cry.

E-yof-kee-hum-pee-taw ......... Supper (before dark).

E-mots-kee-hum-pee-taw ......... Supper (after dark).

Kan-yuk-sa-es-ta-chat-tee .......... Florida red men.

Yo-ho-ee-hee ..............W Whar whoop.

Aw-pox-see-lim-pox-say-nist-lee $\ldots\left\{\begin{array}{l}\text { Day after to-morrow } \\ \text { night. }\end{array}\right.$

Stu-es-taw ............ A great deal, or too much. Ya-ti-ka-chic-co .......... Great Speaker (Commissioner). Munks-chay .....................

Hi-lit-la-ma-es-chay . .......... Too hot (fire water).

Im-e-lo-la-tee-ti-yee $\ldots \ldots \ldots \ldots \ldots$ Water rough.

Ko-no-wa-hum-kin-mo-so-nit-ta-wi- $]$ I want a string of

yy-ches-chee.$\ldots \ldots \ldots \ldots \ldots\}$ beads to-day.

Shot-cay-taw ................ Green Corn Dance.

In-like-e-taw . . . . . . . . . . Heaven.

E-shock-e-tom-e-see.$\ldots \ldots \ldots \ldots\}^{\text {The Supreme Ruler or }}$

E-shock-e-tom-e-see-e-po-chee ......God's son, Christ.

His-a-kit-a-mis-i . . . . . . . . Great Spirit.

Po-ya-fits-a ............... Indian's heaven. 


\title{
THE SEMINOLES OF FLORIDA 2 II
}

\author{
SEMINOLE
}

\section{ENGLISH}

Il-lit $\ldots \ldots \ldots \ldots \ldots \ldots \ldots$ Death.

Som-mus-ka-lar-nee-sha-maw-lin ... Good wishes to white

\section{THE INDIAN NAMES OF SOME PRESENT SEMINOLES}

Tallahassee ................ Mic-co.

So-fan-gee . . . . . . . . . . . Mi-la-kee.

Fi-lan-e-hee . . . . . . . . . . . Tal-la-has-so-wee.

Las-ches-chee $\ldots \ldots \ldots \ldots \ldots \ldots$. . . Fo-ston-sto-noc-ee-la.

Ko-i-hat-cho ............... Cal-lo-fo-nee.

Yee-ho-lo-chee .............. Tol-lo-see.

O-mul-la-gee ............... Shon-o-la-kee.

She-y-o-hee ................ On-nit-chee.

Sla-shing-to-goth-la-gee $\ldots . . \ldots \ldots$. I-o-chus-chee.

Che-e-ho-la ................. Suck-kin-ho-chee.

Sten-o-la-kee ................. Os-ce-o-la.

Cho-fee-hat-cho ...............Mat-lo.

Os-shen-e-ho-la . . . . . . . . . . . Nan-ces-o-wee.

Ho-puth-tee-na-gee ........... Tal-lem-ee.

Tin-fai-yai-ki .............. Kat-ca-la-ni.

Stem-e-o-la-ga .............. Chots-kee.

Ko-nip-hatch-o . . . . . . . . . . Tus-tee-nug-gee.

She-lock-ee . . . . . . . . . . . . . Suc-kin-ho-chee.

Ta-ses-chee ................ Me-take-ee.

Fo-so-wa-tos-to-nock-ee . . . . . . . Cat-sa-ma-tel-e-kee.

I-o-chus-chee $\ldots \ldots \ldots \ldots \ldots \ldots$. Fol-lem-mee.

Hi-e-tee ................. Na-haw.

Hi-ta-kee ................ Ho-ti-yee.

Shon-tee ................. Ful-le-he-le-chee.

Na-gof-tee ................ I-o-la-chee.

Chick-e-o-hee ............... Sten-e-wah-hee.

Cli-so-to-kee-ti-ga ............. Chip-co. 


\section{I2 THE SEMINOLES OF FLORIDA}

\section{RHYTHMICAL, NAMES OF SOME FLORIDA LAKES, RIVERS AND TOWNS}

Imprints of the Vanishing Race are indelibly stamped upon the Geography of Florida

To-hope-ke-li-ga

Ko-mo-ka

Wa-hoo

Chat-ta-hoo-chee

Chip-po-la

Man-a-tee

Mi-am-ee

Ok-a-lo-a-coo-chee

Ta-lu-ga

Ap-pa-lach-i-cola

Pen-sa-co-la

Al-li-ga-tor

O-lus-tee

Wac-cas-sas-see

Ap-pa-lach-ee

O-kee-cho-bee

We-wa-hatch-ka

Oc-ta-hatch-ee

Pic-o-la-ta

Is-ta-chat-ta

In-dian-o-la

Tus-ca-wil-la

Al-la-pa-ha

Wa-bas-so

Is-to-po-ga-yo-ree

Pin-co-la

Tho-not-os-sas-sa

Hic-po-chee

Cho-ko-los-kee
Noc-a-tee

As-ta-tu-la

A-lach-u-a

We-ki-va

Ca-loo-sa-hat-chee

Ock-lo-wa-ha

Ock-lock-o-nee

Choc-ta-what-chee

Hatch-in-a-ha

Is-to-po-ga

Pan-a-soff-kee

Chu-lu-o-ta

Im-mo-ka-lee

Mus-co-gee

Wa-cis-sa

O-kee-fe-no-kee

Su-wan-nee

Nar-coos-see

Kan-yuk-sa

Stein-hatch-ee

Chu-muck-la

Wee-took-ka

Wa-ku-la

La-coo-chee

O-ka-hump-kin

Wa-kee-na

My-ak-ka

O-ka-lo-a-coo-chee

O-ca-la 


\section{THE SEMINOLES OF FLORIDA 2 I 3}

Mic-co-su-kee

Pa-lat-ka

With-la-coo-chee

O-co-ee

A-pop-ka
Ho-mo-sas-sa

O-ce-o-la

Tal-la-hass-ee

Tus-ca-loo-sa

Mic-an-o-pee

Kiss-imm-eé

THE END 








SMITHSONIAN INSTITUTION LIBAARIES

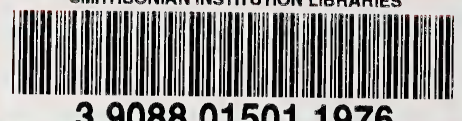

39088015011976 